Title:

Pinellas Plant Annual Site Environmental Report for Calendar Year 1994

Number: $\quad$ MMSC-EM-95011

Issue Date: June 1995

\title{
DOCUMENT CONTROL
}

This document will be maintained in accordance with the sitewide document control procedures. Document control elements include unique issue numbers, document identification, numbered pages, document distribution records, revision tracking, a document MASTER filing and retrieval system, and a document archiving system.

Lockheed Martin Specialty Components

P. O. Box 2908 - Largo, FL 34649-2908

Management and Operating Contractor for the Pinellas Plant under U. S. Department of Energy Contract No. DE-AC04-92AL73000 
This page left blank intentionally. 


\section{DISCLAIMER}

This report was prepared as an account of work sponsored by an agency of the United States Government. Neither the United States Government nor any agency thereof, nor any of their employees, make any warranty, express or implied, or assumes any legal liability or responsibility for the accuracy, completeness, or usefulness of any information, apparatus, product, or process disclosed, or represents that its use would not infringe privately owned rights. Reference herein to any specific commercial product, process, or service by trade name, trademark, manufacturer, or otherwise does not necessarily constitute or imply its endorsement, recommendation, or favoring by the United States Government or any agency thereof. The views and opinions of authors expressed herein do not necessarily state or reflect those of the United States Government or any agency thereof. 


\section{DISCLAIMER}

Portions of this document may be illegible in electronic image products. Images are produced from the best available original document. 
Lockheed Martin Specialty Components Approval:

DDesanonitle

D. Delaneuville, Manager

Waste Management/Minimization

C. A. Biedermann, Manager

Environmental Restoration and Permitting

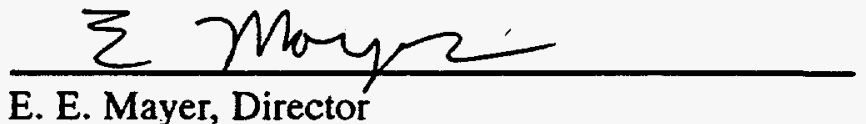

E. E. Mayer, Director

Environmental, Safety and Health

Department of Energy/Pinellas Area Office Approval:

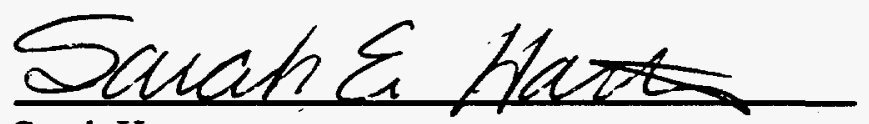

Sarah Hartson

Environmental Compliance Specialist

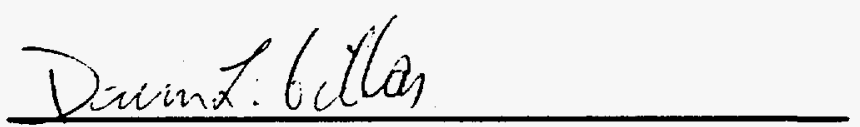

D. Gillas, Team Leader

Environmental Programs

\section{REVIEWED FOR CLASSIFIED:}

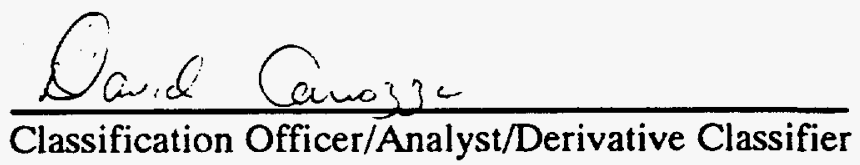

Cuc

Classification Level
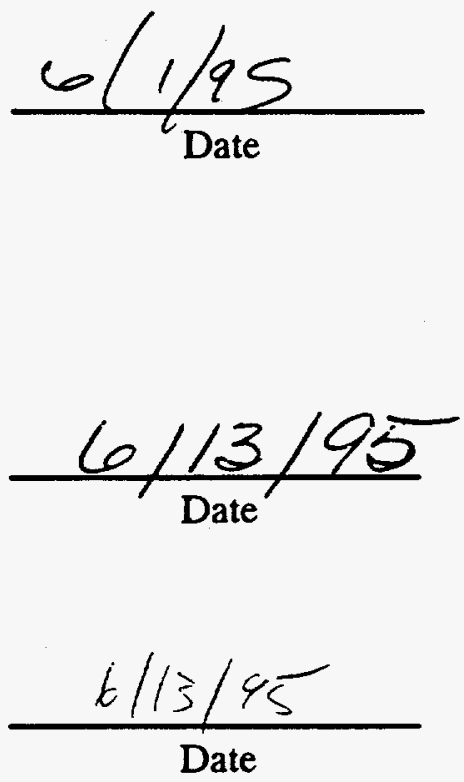

$\frac{5 / 22 / 6,5}{\text { Date }}$ 
This page left blank intentionally. 


\section{ACRONYMS}

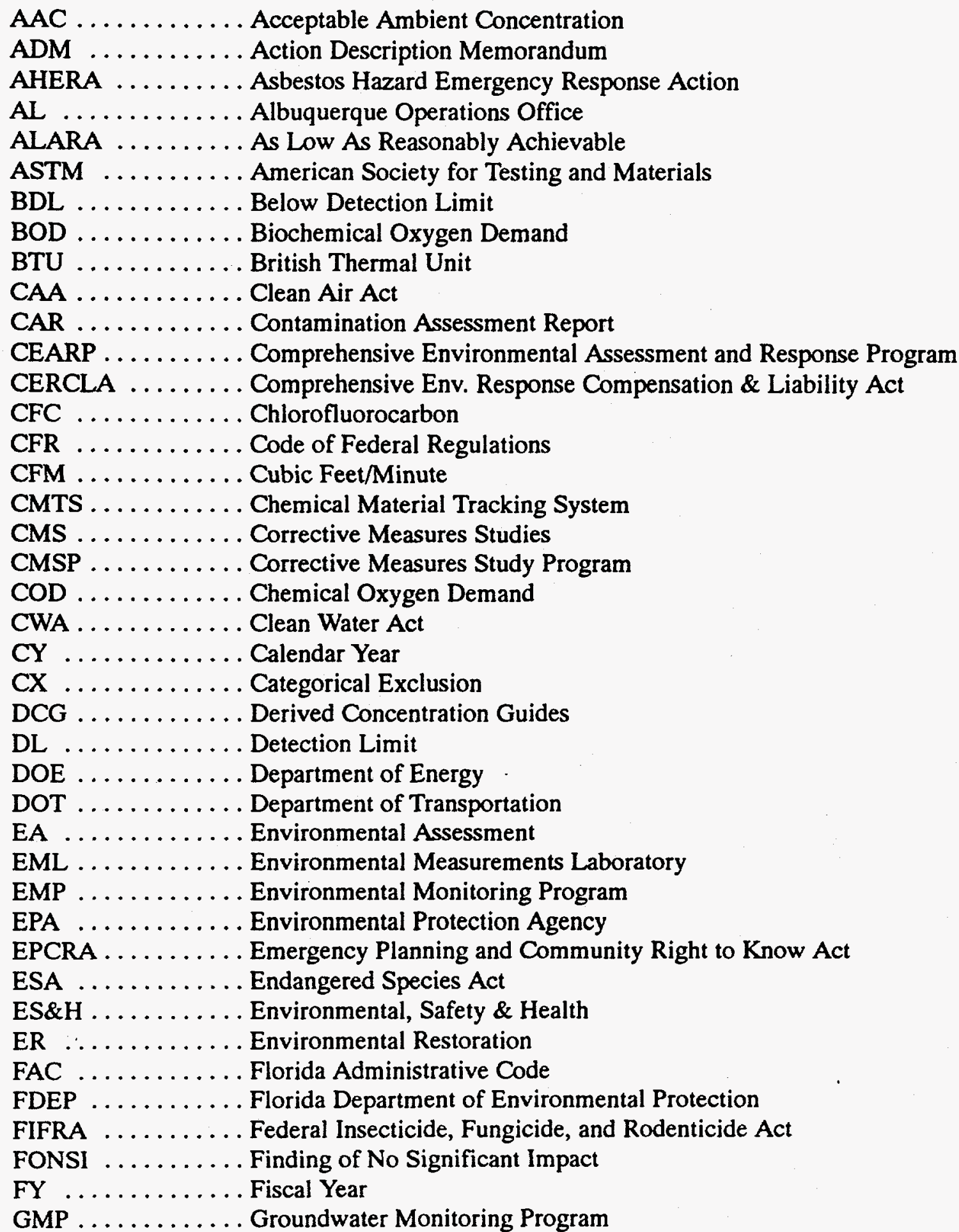




\section{ACRONYMS (CONTINUED)}

GPMP ......... Groundwater Protection Management Program

GOP $\ldots \ldots \ldots \ldots$ General Operating Policy

HAPs .......... Hazardous Air Pollutants

HAZMAT ........ Hazardous Material Response Team

HRS ........... State of Florida Dept. of Health and Rehabilitative Services

HSWA ......... Hazardous and Solid Waste Amendments

ICM ........... Interim Corrective Measure

IFPS $\ldots \ldots \ldots \ldots$ Iron Filling Pilot Study

IRA ........... Interim Remedial Action

ITRD .......... Innovative Treatment Remediation Demonstration

IWNF .......... Industrial Wastewater Neutralization Facility

LDR .......... Land Disposal Restriction

LLMW .......... Low Level Mixed Waste

LLW ........... Low Level Waste

MAC $\ldots \ldots \ldots \ldots$ Maximum Ambient Concentrations

MCL ........... Maximum Contaminant Level

MDL ........... Method Detection Limit

MEI ............ Most Exposed Individual

MSDS ........... Material Safety Data Sheet

MSL ............ Mean Sea Level

NDL .......... New Directions in Learning Child Development and Partnership School

NEPA .......... National Environmental Policy Act

NESHAP . . . . . . National Emission Standards for Hazardous Air Pollutants

NHPA ......... National Historic Preservation Act

NOD ........... Notice of Deficiency

NPDES . . . . . . National Pollutant Discharge Elimination System

NTL .......... No-Threat-Level

NTS ........... Nevada Test Site

OC $\ldots \ldots \ldots \ldots$ Organic Compound

OSHA $\ldots \ldots \ldots \ldots$ Occupational Safety and Health Administration

PAH $\ldots \ldots \ldots \ldots$. Polyaromatic Hydrocarbons

PAO $\ldots \ldots \ldots \ldots$. Pinellas Area Office

PCAQD ......... Pinellas County Air Quality Division

PCB $\ldots \ldots \ldots \ldots$. Polychlorinated Biphenyl

PCIC ........... Pinellas County Industry Council

PCSS .......... Pinellas County Sewer System

PCWS ........... Pinellas County Water System

ppb ............ Parts Per Billion

ppm ........... Parts Per Million

PPOA $. . . . . \ldots .$. Pollution Prrevention Opportunity Assessment

POTW .......... Publicly Owned Treatment Works

PRP $\ldots \ldots \ldots \ldots$. Potentially Responsible Party

QA ........... Quality Assurance

QAPP .......... Quality Assurance Program Plan

QPP ........... Quality Program Plan

RCRA .......... Resource Conservation and Recovery Act 


\section{ACRONYMS (CONTINUED)}

RFA ......... RCRA Facility Assessment

RFI .......... RCRA Facility Investigation

RTG ........... Radioisotopically Powered Thermoelectric Generator

SARA ........... Superfund Amendment and Reauthorization Act

SDWA $\ldots \ldots \ldots$...... Safe Drinking Water Act

SWFWMD ....... Southwest Florida Water Management District

SI $\ldots \ldots \ldots \ldots \ldots$ International System of Units

SPCC .......... Spill Prevention, Control and Countermeasures Plan

SWMU ........... Solid Waste Management Unit

TCA ...........1,1,1-Trichloroethane

TCLP .......... Toxicity Characteristic Leaching Procedure

TOC ........... Total Organic Carbon

TSCA .......... Toxic Substances Control Act

TRS ........... Tritium Recovery System

TSA $\ldots \ldots \ldots \ldots$ Technical Safety Appraisal

TSS ........... Total Suspended Solids

TTO ........... Total Toxic Organic

USGS .......... United States Geological Survey

UST $\ldots \ldots \ldots \ldots$ Underground Storage Tank

VOC ........... Volatile Organic Compound

WM $\ldots \ldots \ldots \ldots$ Waste Management 
This page left blank intentionally. 


\section{TABLE OF CONTENTS}

Section

$\begin{array}{ll}\text { EXECUTIVE SUMMARY } & 1\end{array}$

$1.0 \quad$ INTRODUCTION $\quad 1-1$

1.1 Site and Installation Description $1-1$

1.2 Climatology 1-3

1.3 Weather and Air Pollution $1-4$

1.4 Seismology $1-12$

1.5 Land Use 1-14

$\begin{array}{lll}1.6 & \text { Population } & 1-16\end{array}$

$\begin{array}{lll}1.7 & \text { Water } & 1-17\end{array}$

2.0 COMPLIANCE SUMMARY $\quad 2-1$

2.1 Compliance Status $2-1$

2.1.1 Clean Air Act 2-1

2.1.2 Clean Water Act $2-2$

2.1.3 Safe Drinking Water Act 2-4

2.1.4 Resource Conservation and Recovery Act 2-5

2.1.5 Comprehensive Environmental Response, Compensation, 2-7 and Liability Act

2.1.6 National Environmental Policy Act $2-7$

2.1.7 Toxic Substances Control Act $2-8$

2.1.8 Federal Insecticide, Fungicide and Rodenticide Act 2-8

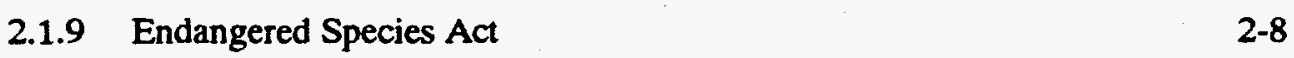

2.1.10 National Historic Preservation Act 2-8

2.1.11 Executive Order 11988, "Floodplain Management" $2-9$

2.1.12 Executive Order 11990, "Protection of Wetlands" 2-9

2.1.13 Emergency Planning and Community Right to Know 2-9 Act of 1986

2.2 Other Major Environmental Issues and Actions 2-9

2.2.1 Tiger Team Assessment of the Pinellas Plant, January $1990 \quad 2-12$ 


\section{TABLE OF CONTENTS (CONTINUED)}

Section

2.3 Summary of Permits . $\quad 2-12$

$\begin{array}{lll}\text { 2.3.1 RCRA Permit } & 2-12\end{array}$

$\begin{array}{ll}\text { 2.3.2 Industrial Wastewater Discharge Permit } & \text { 2-13 }\end{array}$

$\begin{array}{ll}\text { 2.3.3 Stormwater Discharge Permit 2-13 } & \text { 2-13 }\end{array}$

2.3.4 Air Emissions Permit $\quad$ 2-13

3.0 ENVIRONMENTAL PROGRAM INFORMATION 3-1

3.1 Environmental Monitoring Summary 3-1

3.1.1 Nonradiological Monitoring 3-1

3.1.2 Radiological Monitoring 3-4

3.1.3 Groundwater Quality 3-6

3.2 Compliance with the NEPA 3-7

3.3 Significant Environmental Activities 3-14

$\begin{array}{ll}\text { 3.3.1 Pollution Abatement } & 3-14\end{array}$

$\begin{array}{ll}\text { 3.3.2 Special Studies } & \text { 3-16 }\end{array}$

3.4 Assessments 3-16

3.5 Pollution Prevention and Waste Minimization 3-17

3.6 Reports and Certifications 3-18

3.7 Training 3-18

4.0 ENVIRONMENTAL RADIOLOGICAL PROGRAM INFORMATION 4-1

4.1 Radiation Dose Terminology and Dose Standards 4-1

4.2 Radioactive Effluent Data 4-2

4.2.1 Air $\quad 4-2$

4.2.2 Water 4-5

4.3 Environmental Sampling for Radioactivity 4-5

4.3.1 Air 4-6

4.3.2 Water $4-9$

$\begin{array}{lll}\text { 4.3.3 Soil } & \text { 4-12 }\end{array}$

4.4 Evaluation of Potential Dose to the Public 4-15

4.4.1 Dose Standards 4-15

4.4.2 Dose to the Public Due to Naturally Occurring Radiation 4-15

4.4.3 Potential Dose to the Population Within 50 Miles of the Plant Site 4-16

4.4.4 Potential Dose to the Most Exposed Individual of the Public 4-17

4.4.5 Potential Dose Due to Plutonium 4-18

4.4.6 Minor Source Compliance 4-18 


\section{TABLE OF CONTENTS (CONTINUED)}

Section

4.5 Unplanned Releases and Environmental Occurrences 4-18

4.6 ALARA Program 4-19

5.0 ENVIRONMENTAL NONRADIOLOGICAL PROGRAM INFORMATION $\quad$ 5-1

5.1 Atmospheric Nonradiological Emissions 5-1

5.2 Water $5-2$

5.2.1 Wastewater 5-2

5.2.2 Surface Water $5-7$

5.2.3 Stormwater $\quad 5-7$

5.3 Environmental Occurrences $\quad 5-7$

5.4 SARA Title III Reporting 5-8

5.5 Continuous Release Reporting 5-8

6.0 GROUNDWATER PROTECTION PROGRAM 6-1

6.1 Introduction 6-1

6.2 Description of the Groundwater Monitoring Program 6-2

6.3 Hydrogeology 6-3

6.4 Description and Groundwater Results of Areas of Potential 6-5

Environmental Concern

6.4.1 Procedures and Results 6-12

6.4.2 Floridan Aquifer 6-15

6.4.3 Perimeter Surveillance Network 6-15

6.4.4 4.5 Acre Site 6-16

6.4.5 Solid Waste Management Units $\quad$ 6-22

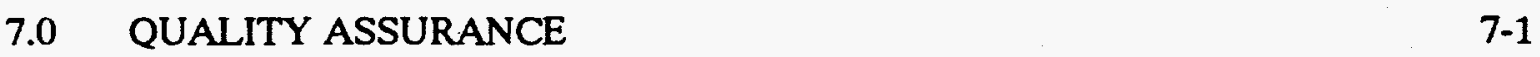

$\begin{array}{lll}7.1 & \text { Nonradioactive Effluent } & \mathbf{7 - 2}\end{array}$

7.2 Radioactive Effluent and Monitoring 7-3

$\begin{array}{lll}7.3 & \text { Data Management } & \text { 7-4 }\end{array}$

7.4 Proficiency Testing Programs 7-4

7.5 QA Program for Meteorology Station 7-8

7.6 Audit Program 7-8

8.0 REFERENCES $\quad$ 8-1

$\begin{array}{lll}9.0 & \text { DISTRIBUTION } & \text { 9-1 }\end{array}$ 


\section{TABLE OF CONTENTS (CONTINUED)}

\section{ILLUSTRATIONS}

Number

1-1 State of Florida Map

1-2 Pinellas County Map

1-3 January 1994 Pinellas Plant Wind Rose

1-4 July 1994 Pinellas Plant Wind Rose

1-5 Pinellas Plant 1994 Annual Wind Rose

1-6 Seismic Risk Map of the United States

1-7 Pinellas Plant Site Layout

3-1 Regulated Liquid Effluent Releases Above Detectable Limit, 1994

4-1 On-Site Exhaust Stack and Ambient Air Sampling Station Locations

4-2 Tritium Stack Emissions, 1994

4-3 Off-Site Air Sampling Station Locations

4-4 Off-Site Surface Water Sampling Locations

4-5 On-Site Soil Sampling Locations

4-6 Off-Site Soil Sampling Locations

5-1 Pinellas Plant Actual 1994 VOC/OC Emissions

5-2 Nonradiological Liquid Effluent Sampling Locations, 1994

5-3 Regulated Liquid Effluent Above Detection Limit, 1994

6-1 Generalized Geologic Cross-Section in the Vicinity of the Pinellas Plant

6-2 Water Table Map - January 1994

6-3 Water Table Map - April 1994

6-4 Water Table Map - July 1994

6-5 Water Table Map - October 1994

6-6 Potentiometric Surface of the Upper Floridan Aquifer, September 1992

6-7 Location of Perimeter Groundwater Monitoring Wells

6-8 Location of Groundwater Monitoring Wells, Piezocone and Hydrocone Sampling 6-19

6-9 Concentration of Total VOCs Recovery Well 4.5 MW-6

6-10 Concentration of Total VOCs Recovery Well 4.5 R-3

6-11 Concentration of Total VOCs Recovery Well 4.5 R-4 


\section{ILLUSTRATIONS (CONTINUED)}

Number

Page

6-12 Area of Potential Environmental Concern at the Pinellas Plant

6-13 Regulatory Steps of Remediation

6-26

6-14 Concentration of Total VOCs Monitor Well NEMW-2S

6-28

6-15 Concentration of Total VOCs Monitor Well NEMW-3D

6-16 Concentration of Total VOCs Monitor Well NEMW-4

6-17 Recovery of VOCs in Pinellas Plant Groundwater Treatment System Since May 1990

\section{TABLES}

Number

Page

1-1 Pinellas Plant Meteorological Station Wind Frequency Distribution, 1994, by Wind Speed, Stability Class, and Origin

1-2 1994 Monthly Statistical Summaries of Pinellas Plant Meteorological Monitoring Station

1-3 Pinellas County Population Statistics

1-4 1990 Population by Sector-Segment

2-1 Clean Air Act Requirements with Significant Impacts at the Pinellas Plant

3-1 Summary of Air Environmental Monitoring at the Pinellas Plant in 1994

3-2 Summary of Total Radiological Stack Emission (Tritium and Kr-85) for 1994

3-3 Tritium Discharged to PCSS, 1994

3-4 Summary of Groundwater Monitoring Results

3-5 NEPA Documentation as of December 31, 1994

4-1 1994 Stack Releases to the Atmosphere

4-2 Tritium Released in the Combined Wastestream to the PCSS in 1994

4-3 1994 On-Site Ambient Air Sampling Results

4-4 1994 Off-Site Ambient Air Sampling Results

4-5 On-Site Surface Water Tritium Concentrations

4-6 Soil Sample Location Schedule 


\section{TABLES (CONTINUED)}

Number

5-1 1994 Actual Emissions

5-2 Combined Nonradiological Liquid Effluent Analysis Results

5-3 PCSS and Pinellas Plant Wastewater Split Sample Comparison

5-4 Report of Pinellas Plant's Compounds for Calendar Year 1994

6-1 Pinellas Plant Groundwater Monitoring Program

6-2 Tritium Groundwater Sample Concentrations

6-3 Metal Groundwater Sample Concentrations

6-4 VOC Groundwater Sample Concentrations

6-5 Pinellas Plant Groundwater Elevation Data

6-6 4.5 Acre Site Historic High Versus Current High

6-7 Pinellas Plant SWMUs

7-1 Wastewater Sampling Schedule

7-2 QA Sample Frequency Requirements

7-3 Third-Party Quality Assurance Program Summary

7-4 1994 Results of Analysis of Spiked Samples Provided by Government Third-Party Quality Assurance Programs

7-5 1994 Results, Commercial Third-Party Quality Assurance Program (Analytical Products Group, Inc.) 


\section{EXECUTIVE SUMMARY}

Lockheed Martin Specialty Components, and the U.S. Department of Energy are committed to successfully administering a high-quality Environmental, Safety and Health Program at the Pinellas Plant in Pinellas County, Florida (Figure 1-1). Part of this commitment includes accurately documenting and communicating to the Pinellas Plant stakeholders the results of the Pinellas Plant's environmental compliance and monitoring activities. The Annual Site Environmental Report presents a comprehensive summary of the results of the Environmental Monitoring, Waste Management, and Environmental Restoration Programs at the Pinellas Plant for 1994. This report also includes the plant's performance in the areas of compliance with applicable regulatory requirements and standards and identifies major Environmental, Safety and Health Program initiatives and accomplishments for 1994. This report satisfies the requirements specified in DOE 5400.1, General Environmental Protection Program and DOE 5484.1, Environmental Protection, Safety and Health Protection Information Reporting Requirements.

As a result of the end of Department of Energy Defense Programs mission production on September 30, 1994, considerable changes at the Pinellas Plant occurred. These changes, which included transitioning the plant toward alternate use in support of economic development and safe shutdown, both increased and heightened Environmental, Safety and Health responsibilities. In December 1994, the Department of Energy announced it had reached an agreement to sell the Pinellas Plant to the Pinellas County Industry Council in March 1995. The plant is being leased back by the Department of Energy through September 1997 to complete safe shutdown, reconfiguration, transfer of equipment to other Department of Energy production facilities, and transition to commercial ventures. Permit modifications and transfers will be completed during 1995 to reflect the new ownership by the Pinellas County Industry Council and to include new tenants as needed.

The major sections of the Annual Site Environmental Report are summarized below:

\section{COMPLIANCE SUMMARY}

The Environmental, Safety and Health Division at the Pinellas Plant met all the challenges associated with the plant's changing environment and maintained their excellent compliance record during 1994.

The Pinellas Plant discharges industrial wastewater and untreated sanitary sewage to the Pinellas County Sewer System Publicly Owned Treatment Works in accordance with the plant's Industrial Wastewater Discharge Permit, 153-IE, renewed August 28, 1994. The 1994 discharges did not exceed the permit limits, Federal Metal Finishing Pretreatment Standards, or Pinellas County Ordinance 91-26. On August 11, 1994, the Pinellas County Sewer System performed a site inspection that included a review of production areas and the wastewater treatment process. No violations or noncompliances were identified.

The Pinellas Plant does not currently have a National Pollutant Discharge Elimination System permit for stormwater discharge associated with industrial activities. A permit application was submitted to the Environmental Protection Agency in September 1992 and revised in April 1994. To date, the plant has not received a stormwater discharge permit from the U.S. Environmental Protection Agency, but will comply with the requirements once it is received. 
On February 4, 1994, the Florida Department of Environmental Protection issued a plantwide air emissions permit to the Pinellas Plant. This permit defines chemical air emissions limits. The plant provides routine updates to both the Pinellas County Air Quality Division and the Florida Department of Environmental Protection to reflect changes in plant operations pursuant to air permit requirements. On September 13, 1994, the Pinellas County Air Quality Division inspected the Pinellas Plant for compliance to the Air Operating Permit. The Pinellas County Air Quality Division documented in their report that the plant is in compliance with all conditions of the permit.

The Florida Department of Environmental Protection renewed the Pinellas Plant's Hazardous Waste Facility Permit, with an effective date of December 8, 1994. The Pinellas Plant stores and/or treats hazardous wastes, but no hazardous wastes are disposed of on the plant site. The Florida Department of Environmental Protection and/or the Environmental Protection Agency inspect the plant's hazardous waste operations at least annually to assure compliance with governing regulations. On November 9, 1993, the Florida Department of Environmental Protection performed an unannounced inspection and identified two violations. One of these violations was dismissed after the plant submitted additional information to the Florida Department of Environmental Protection. The other violation was resolved when the plant submitted a contingent post-closure plan for a hazardous waste storage tank. In April 1994, the Florida Department of Environmental Protection and the Pinellas Plant signed a short form consent order settlement. This consent order stated that "the corrective actions required to bring the facility into compliance have been performed." On February 7, 1994, the Florida Department of Environmental Protection performed the annual Resource Conservation and Recovery Act Hazardous Waste Permit inspection. The Florida Department of Environmental Protection has not yet issued a final report.

In addition to on-site remediation, cleanup of contamination sites on the Pinellas Plant property is conducted under the requirements of the Resource Conservation and Recovery Act, Hazardous and Solid Waste Amendments Permit issued to the Department of Energy on February 9, 1990. During 1994, activities under this permit included the following: (1) completed a statement of basis for no further action at 12 of the 15 originally identified solid waste management units, (2) completed and received approval for two corrective measures studies addressing cleanup of contamination at the three remaining solid waste management units, (3) operated and maintained ongoing groundwater cleanup interim measures at the Northeast Site solid waste management unit, (4) discovered buried drums at the Northeast Site solid waste management unit and subsequently prepared an addendum to the interim measures for their removal, (5) received regulatory agency approval to implement an additional interim measure to cleanup contaminated groundwater at a new solid waste management unit (West Fenceline Site), and (6) identified and assessed another solid waste management unit (Wastewater Neutralization Area/Building 200 Area Site). The Pinellas Plant's aggressive characterization and cleanup activities continued to go beyond the requirements of the permit during 1994 by accelerating cleanup activities through interim remedial actions and by closely coordinating with the regulatory agencies on the Pinellas Plant Environmental Restoration Program.

Accelerated cleanup actions of the solvent-contaminated groundwater at the adjacent 4.5 Acre Site continued through 1994. The remediation technique employed, pump and treat, draws the industrial solvent contaminants back onto the site and reduces the overall concentration of these 
contaminants in the groundwater through a series of strategically located recovery wells. The 4.5 Acre Site is currently a voluntary action, although a consent agreement with the regulatory agency (Florida Department of Environmental Protection) will be negotiated.

The Pinellas Plant is currently involved as a potentially responsible party in the assessment of one Comprehensive Environmental Response, Compensation, and Liability Act site, Peak Oil. Peak Oil was a used oil reclamation facility and has been placed on the National Priorities List by the Environmental Protection Agency. The Environmental Protection Agency provided a de minimis settlement offer to the Department of Energy on December 28, 1994.

Significant 1994 National Environmental Policy Act activities included one Environmental Assessment, the Commercialization of the Pinellas Plant. On August 15, 1994, the Assistant Secretary of Energy for Environment, Safety and Health issued a Finding of No Significant Impact for the proposed action in the Environmental Assessment for the Commercialization of the Pinellas Plant.

\section{ENVIRONMENTAL PROGRAM}

The basis for the Environmental Monitoring Program is identified in the Pinellas Plant Environmental Monitoring Plan. The plan establishes a monitoring program specifically designed to detect radiological and nonradiological releases to the air, soil, surface waters, and groundwater. Trends in environmental data are monitored to verify progress of contaminated site cleanup and early warning so that corrective actions can be implemented prior to exceeding regulatory standards. All monitoring is in accordance with approved procedures. These procedures are reviewed regularly and updated annually to incorporate the latest technical and regulatory developments.

\section{Environmental Radiological Monitoring Program}

In 1994, the Pinellas Plant operated within applicable regulatory limits for both radiological and nonradiological discharges to the air and water. Periodic confirmatory measurements verified the compliance status. On November 3, 1994, the Florida Department of Health and Rehabilitative Services Office of Radiation Control performed an annual inspection of the plant for compliance with their regulations on radiological air and wastewater effluents and validated the self-monitoring data.

Radiological releases at the plant occur through the air and industrial wastewater discharge pathways. The Environmental Radiological Monitoring Program includes wastewater, exhaust stack, on- and off-site air, surface water, and soil sampling.

In 1994, the air monitoring program included continuous sampling of six exhaust stacks and eleven on-site and six off-site sampling stations. Between 1975 and 1991, the Radioisotopicallypowered Thermoelectric Generator product was manufactured at the Pinellas Plant which utilized a small triply-sealed plutonium heat source. All plutonium heat sources were carefully controlled and removed from the site by February 1991. The Environmental Radiological Monitoring Program analyzes air and soil samples to confirm there was never a release of plutonium. No plutonium was detected from past manufacturing. Tritium and krypton-85 
releases continue to be well below standards set by the Department of Energy and the Environmental Protection Agency. During 1994, the plant released into the atmosphere a total of 24.95 curies of tritium and 12.9 curies of krypton-85. The 1994 releases were slightly above the previous year's releases due to an increase in production to meet DOE goals.

The estimated dose to the population within a 50-mile radius of the plant in 1994 was estimated by the CAP88-PC computer code to be $9.71 \times 10^{-2}$ person-rem/yr. The calculated dose to the most exposed individual was also estimated by CAP88-PC to be $5.6 \times 10^{-3} \mathrm{mrem} / \mathrm{yr}$, which is well below the Environmental Protection Agency and the Department of Energy standards of 10 $\mathrm{mrem} / \mathrm{yr}$.

The Environmental Monitoring Program includes sampling of the industrial wastewater discharges and on- and off-site surface water. Pinellas Plant monitoring personnel collected surface water samples from three on-site ponds and twenty-six off-site ponds, ditches, and lakes and analyzed them for tritium. The annual average concentrations of tritium in the on-site and off-site surface waters were less than the Department of Energy derived concentration guides standard for drinking water of $2.0 \times 10^{3} \mathrm{pCi} / \mathrm{ml}$. All water and wastewater samples were well below regulatory standards and health-based limits for radionuclides. All soil samples collected showed no traces of plutonium from previous plant operations.

\section{Environmental Nonradiological Monitoring Program}

Nonradiological releases at the plant occur through the industrial wastewater discharge and air pathways. The Nonradiological Monitoring Program includes routine sampling of industrial wastewater and periodic confirmatory sampling of fenceline ambient air concentrations.

Specialty Components Environmental, Safety and Health personnel sampled the industrial wastewater discharge and analyzed it for pollutants identified in the plant wastewater discharge permit. Analyses are performed for metals (e.g., lead, mercury and cadmium), total suspended solids, biochemical oxygen demand, and total toxic organics. The $\mathrm{pH}$ is monitored continuously. Releases of regulated pollutants in 1994 were at consistently low levels and well below regulatory limits.

The Pinellas Plant compliance with fenceline ambient air concentrations in 1994 was verified to be below regulatory limits through the use of air dispersion computer models. Total 1994 plant emissions of volatile organic compounds/organic compounds were well below permit limits.

\section{Groundwater Protection}

Specialty Components Environmental, Safety and Health personnel administer the Groundwater Protection Management Program at the Pinellas Plant. This program's objectives include the following: to monitor groundwater to demonstrate compliance with applicable regulations, to provide data to permit early detection of contamination, and to determine effectiveness of groundwater cleanup actions.

During 1994, the Pinellas Plant collected approximately 1282 groundwater samples from 135 monitoring wells. The results indicate groundwater contamination is limited to isolated areas of the on-site shallow surficial aquifer and no contamination occurred in the deep drinking water 
aquifer. The primary contaminants of concern are common industrial solvents, such as trichloroethene and methylene chloride. Groundwater recovery and subsequent treatment continue to successfully reduce contaminant concentrations.

\section{QUALITY ASSURANCE}

The Quality Assurance Program for environmental monitoring is documented in the Quality Program Plan for Environmental Monitoring, MMSC-QPP-0028. This plan is written to meet the requirements of DOE 5700.6, Quality Assurance, and 10 Code of Federal Regulations 830.120 and identifies specific requirements for the management, performance, assessment, and continuous improvement of environmental monitoring. The plan provides a systematic approach to environmental monitoring and establishes a program to ensure regulatory requirements are met. The plan is also consistent with and supplemented by the Quality Program Plan for Environmental, Safety and Health Programs, MMSC-QPP-0033. 
This page left blank intentionally. 


\subsection{INTRODUCTION}

The 1994 Pinellas Plant Annual Site Environmental Report presents, in summary form, environmental data that characterizes the performance of site environmental management efforts, confirms compliance with environmental standards and requirements, and highlights significant programs and efforts. It presents summary data for the Environmental Monitoring Program, which is conducted in accordance with the Pinellas Plant Environmental Monitoring Plan [Ref. 1].

Lockheed Martin Specialty Components (Specialty Components) Environmental, Safety and Health used the following documents in preparing this report:

- DOE 5400.1, General Environmental Protection, June 1990 [Ref. 2].

- DOE 5400.5, Radiation Protection of the Public and the Environment, February 1990 [Ref. 3].

- DOE 5484.1, Environmental Protection, Safety and Health Protection Information Reporting Requirements, October 1990 [Ref. 4].

- Final Guidance for the Preparation of Annual Site Environmental Reports for Calendar Year 1994, Office of Environmental Policy and Assistance, April 6, 1995.

\subsection{Site and Installation Description}

Until March 1995, at which time the United States Department of Energy (DOE) finalized the sale of the Pinellas Plant to the Pinellas County Industry Council (PCIC), the plant was owned by the DOE. The plant is being leased back to the DOE through September 1997, to complete safe shutdown, reconfiguration, transfer of equipment to other DOE production facilities, and transition to commercial ventures. The plant continues to be managed and operated by Specialty Components under Contract No. DE-AC04-92AL73000. The contract is administered by the DOE Albuquerque Operations Office (AL) through the DOE Pinellas Area Office (PAO). The plant has been an essential part of the nation's Nuclear Weapons Complex, but stopped production of weapons-related components late in 1994.

The plant's mission was small-volume production of selected high-technology nuclear weapon components that required strict control of materials and processes in an ultra-clean environment. These conditions were imposed by the plant's first assignment, the development of neutron generators, used as external initiators of nuclear weapons. The plant's product lines expanded to include lightning arrestor connectors, capacitors, magnetics, optoelectronic devices, and other similar components. Some of these product lines are now being investigated for conversion to commercial and nonmilitary applications.

The plant employs approximately 800 employees. The PAO has approximately 30 employees. The plant area has expanded to over 700,000 square feet from its 1957 beginnings at about 160,000 square feet. Its structures and paved areas 
occupy about $35 \%$ of the 99 -acre site, the rest of which is open space. The site is bordered on the north by light industrial and vacant land, on the east by Belcher Road (County Road 135), on the west by CSX railroad tracks, and on the south by Bryan Dairy Road.

The Pinellas Plant is located in Pinellas County, Florida (Figures 1-1, 1-2), between the cities of Clearwater and St. Petersburg. Originally constructed in an isolated area, the plant site today is surrounded by light industrial and residential areas. The closest residential area is approximately 0.5 kilometer, or 0.3 miles, from the plant. The open space of the site includes two stormwater retention ponds, East Pond and South Pond, and one stormwater detention pond, the West Pond. The total area of these surface waters is approximately five acres.

Manufacturing operations fall into the metal finishing category, as defined by the U.S. Environmental Protection Agency (EPA). Manufacturing processes include electroplating, electroless plating, encapsulation, etching and chemical cleaning, machining, grinding, burnishing, impact deformation, shearing, thermal cutting, welding, brazing, soldering, flame spraying, sand blasting, degreasing, painting, calibration, and testing. This work involves handling small quantities of tritium and krypton-85 (Kr-85). During 1990, the Radioisotopically-powered Thermoelectric Generator (RTG) product line was discontinued. All RTG plutonium heat sources were carefully controlled and removed from the site by February 1991. As by-products of production, a variety of waste materials are generated and are carefully controlled by the plant and regulated by Federal, State, and local agencies.

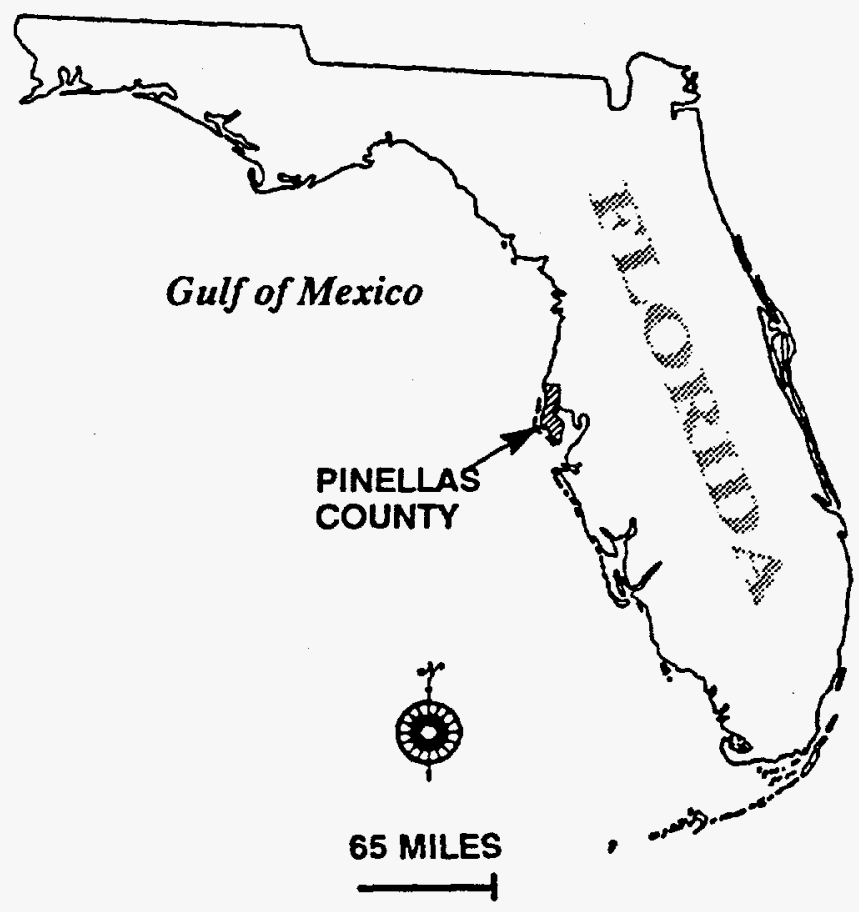

Figure 1-1. State of Florida Map 


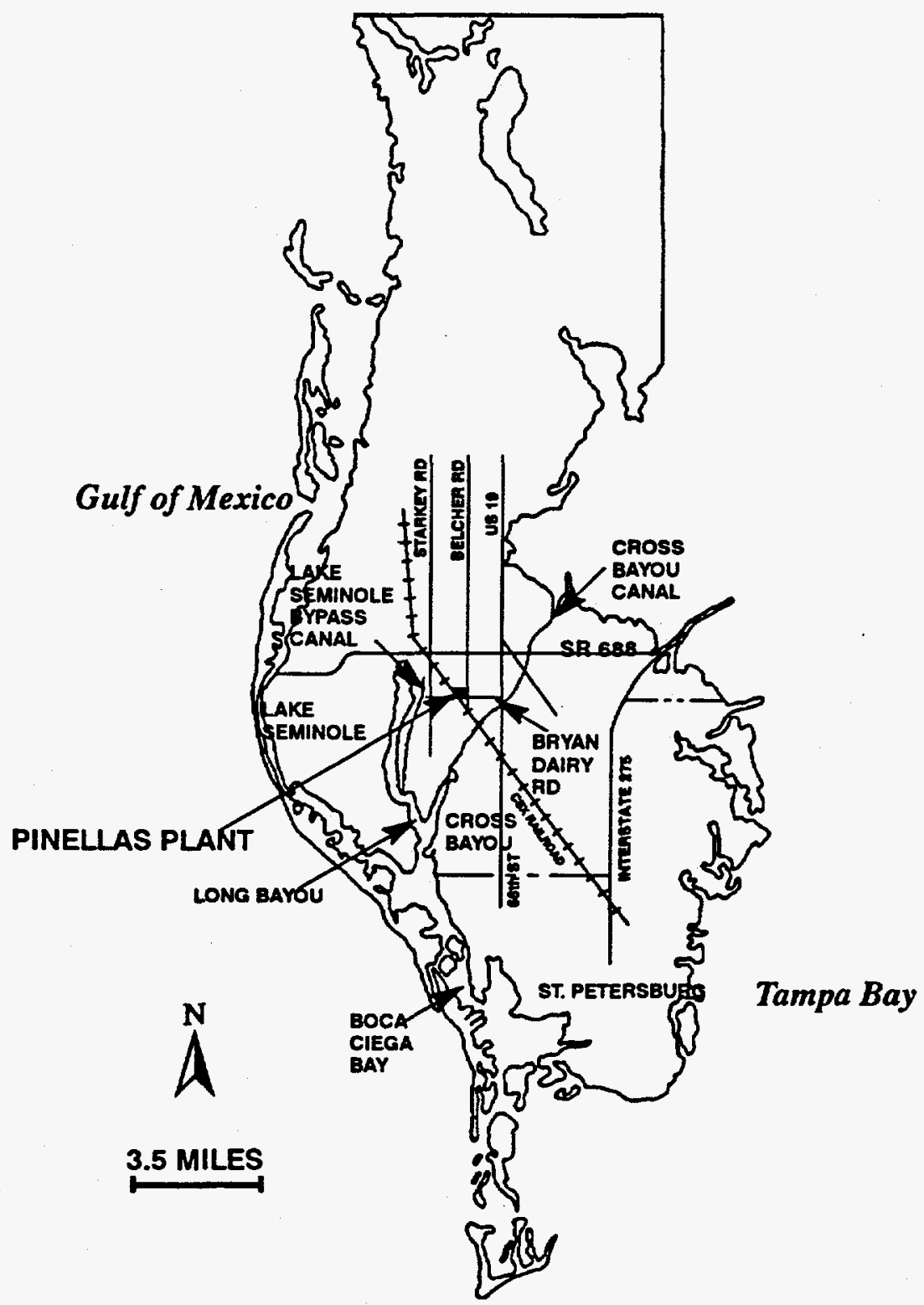

Figure 1-2. Pinellas County Map

\subsection{Climatology}

The climate of the Tampa Bay area is characterized as subtropical, with the primary wet season during the summer and a secondary wet season during winter. Winters are generally mild, with summers being rather long, warm, and humid. Low temperatures average 50 degrees Fahrenheit in the winter and 70 degrees Fahrenheit in the summer. Afternoon highs range from the low $70 \mathrm{~s}$ in winter to around 95 degrees Fahrenheit from June through September. Invasions of cold northern air can produce an occasional cold winter morning. Freezing 
temperatures may occur several mornings a year during December, January, and February. In some years, no freezing temperatures are recorded. Snowfall is very rare.

One prominent feature of the Tampa Bay area's climate is the summer thunderstorm activity. The majority of these occur in the late afternoon hours from June through September. Sudden temperature drops of 15 to 20 degrees Fahrenheit are often associated with these events. The heaviest rains in a 24-hour period average 12 inches and are associated with hurricanes. Hurricane season is from June 1 to November 30.

The Tampa Bay area is characterized by two distinct predominant wind patterns. During two-thirds of the year, regional wind patterns dictate meteorological conditions. These winds are generally from the north to northeast with a wind speed of five to seven miles per hour. This regional wind regime, with its predominant wind origin from the northeast, dominates the winter season. Coastal recirculation wind patterns also play a significant role in Tampa Bay's meteorology and are characterized by the striking feature of a widely distributed wind direction across nearly all compass directions. The coastal recirculation wind patterns are more predominant during summer and are closely associated with the summer thunderstorm activity experienced in the region. These two wind regimes are clearly demonstrated by a comparison of on-site wind data depicted in the wind roses for January and July 1994 (Figures 1-3 and 1-4). The composite wind rose for the entire year of 1994 is shown in Figure 1-5.

\subsection{Weather and Air Pollution}

Ambient air pollutant levels are dictated by the prevailing atmospheric conditions. The primary mechanisms that dictate pollutant dispersion and pollutant concentration levels are wind speed, direction, and atmospheric stability.

Atmospheric stability is defined as the relative ability of a parcel of air to move freely through the effects of mechanical and thermal turbulence, providing greater dilution and dispersion of pollutants. Combined with the various atmospheric stability characteristics of the local area, both the synoptic wind patterns and the coastal recirculation wind patterns play a significant role in determining pollutant levels in the region.

In August 1992, the Pinellas Plant began collecting meteorological data from its new meteorological monitoring station. The station monitors 20 parameters from 12.5- and 30-meter towers, monitors real-time local meteorological conditions, and enhances the Specialty Components Environmental, Safety and Health Division pollutant modeling. With the on-site station, the plant can provide a detailed characterization of local weather conditions throughout the year. 


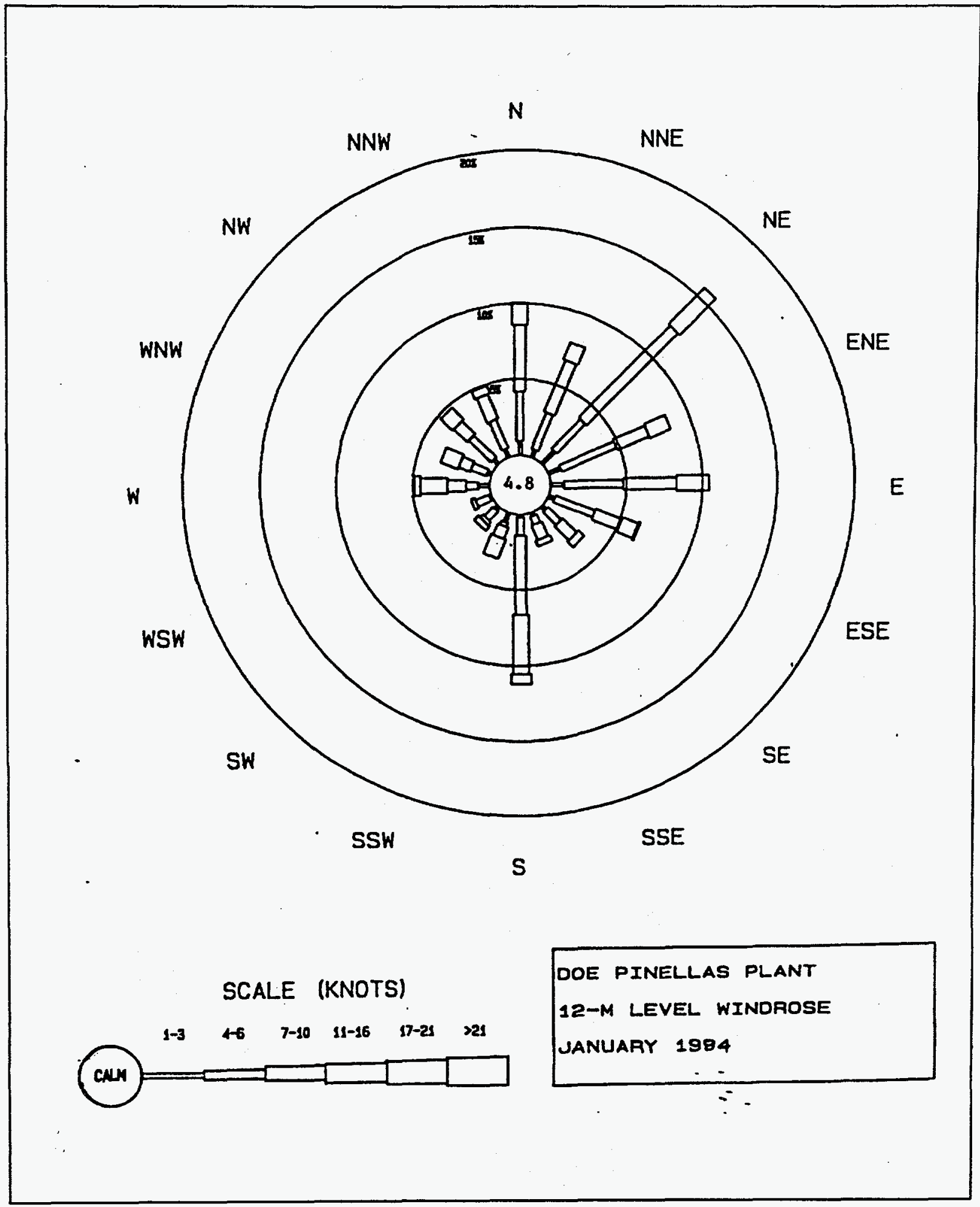

Figure 1-3. January 1994 Pinellas Plant Wind Rose 


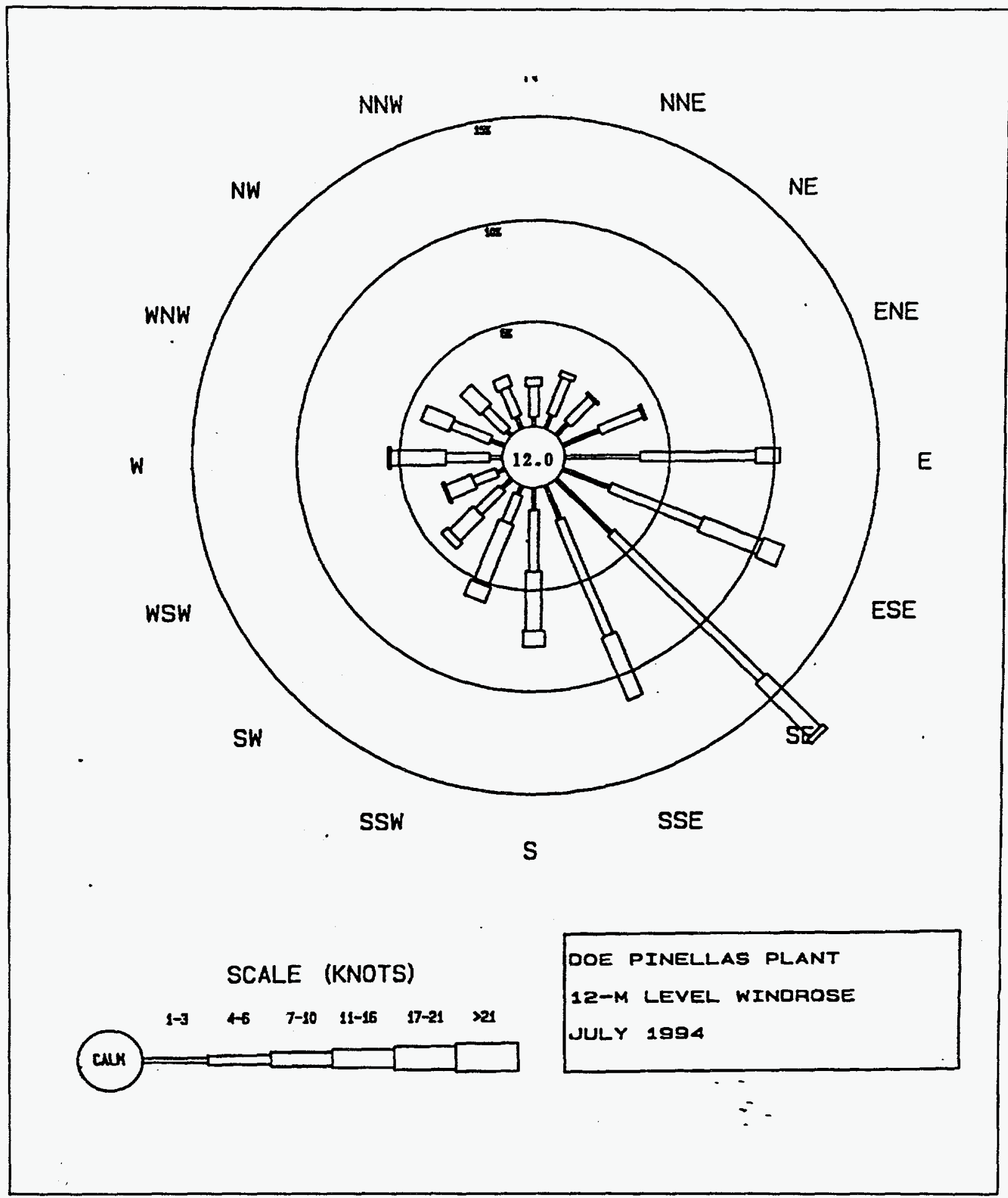

Figure 1-4. July 1994 Pinellas Plant Wind Rose 


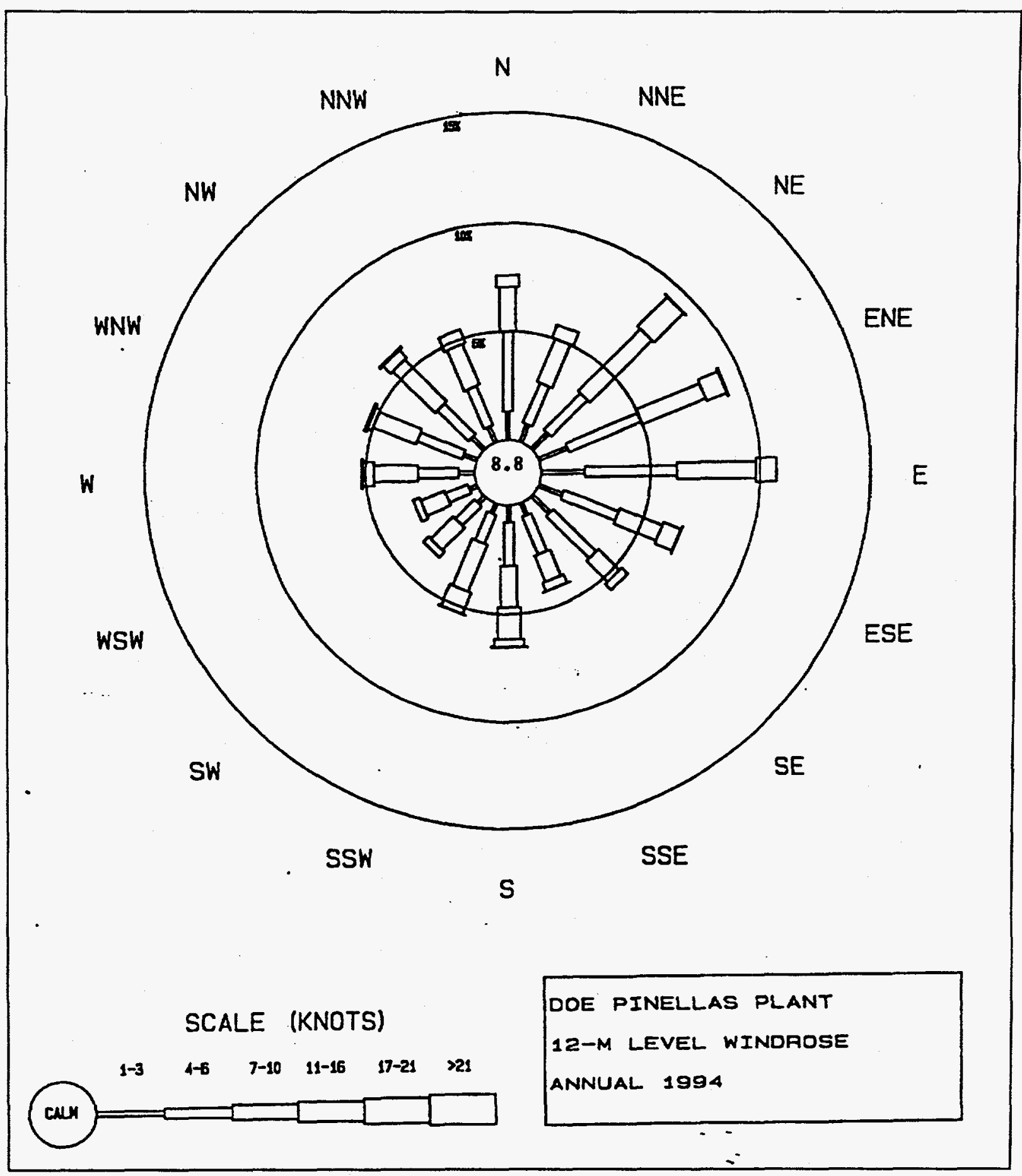

Figure 1-5. Pinellas Plant 1994 Annual Wind Rose 
A relative frequency distribution table for the various wind speed classifications and stability class arrays measured at the Pinellas Plant Meteorological Station during 1994 is shown in Table 1-1. The data presented is a good characterization of the plant's annual wind regime. Wind speeds are reported in knots. The stability classifications were determined from the Pasquill-Gifford scheme, which uses temperature differential gradients and solar radiation intensities to determine atmospheric stability.

During 1994, a comprehensive data comparison of Pinellas Plant on-site meteorological data, Tampa International Airport data, and St. Petersburg International Airport data continued. The study determined both the accuracy and suitability of the Pinellas Plant on-site data for conducting representative dispersion modeling and other special modeling studies using the on-site data versus regionally collected meteorological data. The study reviewed the meteorological data set collected at the DOE site and concludes that all the parameters measured and the calculated data were very representative of the data collected at the Tampa International Airport site. The data from the St. Petersburg location was somewhat less representative. The study determined that the on-site data are of sufficient quality and completeness to be used for air quality modeling applications, thus confirming the use of the data for tasks such as Annual National Emissions Standards for Hazardous Air Pollutants (NESHAP) Radiological Emissions Report or other air dispersion modeling requirements. A summary of the parameters analyzed is provided in Table 1-2. 
Table 1-1. Pinellas Plant Meteorological Station Wind Frequency Distribution, 1994, by Wind Speed, Stability Class, and Origin

(Wind Frequency Distribution at the 12.5 Meter Tower Pinellas Plant-Calendar Year 1994)

\begin{tabular}{|c|c|c|c|c|c|c|c|}
\hline \multirow[b]{2}{*}{$\begin{array}{l}\text { WIND } \\
\text { ORIGIN }\end{array}$} & \multirow{2}{*}{$\begin{array}{c}\text { PASOUILLGIFFORD } \\
\text { STABILITY } \\
\text { CAASS }\end{array}$} & \multicolumn{6}{|c|}{ WIND SPEEDS IN KNOTS } \\
\hline & & 13 & 46 & $7-10$ & $11-16$ & 17.21 & $>21$ \\
\hline $\boldsymbol{N}$ & A & 0.0004 & 0.0009 & 0.0000 & 0.0000 & 0.0000 & 0.0000 \\
\hline NNE & A & 0.0001 & 0.0007 & 0.0000 & 0.0000 & 0.0000 & 0.0000 \\
\hline$N E$ & A & 0.0007 & 0.0005 & 0.0000 & 0.0000 & 0.0000 & 0.0000 \\
\hline ENE & A & 0.0001 & 0.0006 & 0.0000 & 0.0000 & 0.0000 & 0.0000 \\
\hline$E$ & A & 0.0011 & 0.0012 & 0.0000 & 0.0000 & 0.0000 & 0.0000 \\
\hline ESE & $A$ & 0.0004 & 0.0011 & 0.0000 & 0.0000 & 0.0000 & 0.0000 \\
\hline SE & A. & 0.0000 & 0.0010 & 0.0000 & 0.0000 & 0.0000 & 0.0000 \\
\hline SSE & A & 0.0001 & 0.0007 & 0.0000 & 0.0000 & 0.0000 & 0.0000 \\
\hline$s$ & A & 0.0010 & 0.0013 & 0.0000 & 0.0000 & 0.0000 & 0.0000 \\
\hline SSW & A & 0.0000 & 0.0000 & 0.0000 & 0.0000 & 0.0000 & 0.0000 \\
\hline sw & A & 0.0002 & 0.0007 & 0.0000 & 0.0000 & 0.0000 & 0.0000 \\
\hline WSW & A & 0.0001 & 0.0000 & 0.0000 & 0.0000 & 0.0000 & 0.0000 \\
\hline$w$ & A & 0.0002 & 0.0002 & 0.0000 & 0.0000 & 0.0000 & 0.0000 \\
\hline WNW & A & 0.0002 & 0.0002 & 0.0000 & 0.0000 & 0.0000 & 0.0000 \\
\hline$M$ & A & 0.0002 & 0.0000 & 0.0000 & 0.0000 & 0.0000 & 0.0000 \\
\hline NAN & A & 0.0000 & 0.0005 & 0.0000 & 0.0000 & 0.0000 & 0.0000 \\
\hline $\mathbf{N}$ & B & 0.0000 & 0.0007 & 0.0001 & 0.0000 & 0.0000 & 0.0000 \\
\hline NNE & B & 0.0001 & 0.0004 & 0.0000 & 0.0000 & 0.0000 & 0.0000 \\
\hline NE & B & 0.0000 & 0.0017 & 0.0001 & 0.0000 & 0.0000 & 0.0000 \\
\hline ENE & B & 0.0001 & 0.0006 & 0.0000 & 0.0000 & 0.0000 & 0.0000 \\
\hline$E$ & $\mathbf{B}$ & 0.0001 & 0.0010 & 0.0000 & 0.0000 & 0.0000 & 0.0000 \\
\hline ESE & B & 0.0001 & 0.0006 & 0.0001 & 0.0000 & 0.0000 & 0.0000 \\
\hline SE & B & 0.0001 & 0.0011 & 0.0000 & 0.0000 & 0.0000 & 0.0000 \\
\hline SSE & B & 0.0001 & 0.0009 & 0.0000 & 0.0000 & 0.0000 & 0.0000 \\
\hline$s$ & B & 0.0001 & 0.0007 & 0.0000 & 0.0000 & 0.0000 & 0.0000 \\
\hline SSW & B & 0.0001 & 0.0004 & 0.0000 & 0.0000 & 0.0000 & 0.0000 \\
\hline SW & B & 0.0001 & 0.0002 & 0.0001 & 0.0000 & 0.0000 & 0.0000 \\
\hline WSW & B & 0.0000 & 0.0004 & 0.0000 & 0.0000 & 0.0000 & 0.0000 \\
\hline$w$ & $\mathbf{B}$ & 0.0001 & 0.0001 & 0.0000 & 0.0000 & 0.0000 & 0.0000 \\
\hline WNW & B & 0.0000 & 0.0007 & 0.0000 & 0.0000 & 0.0000 & 0.0000 \\
\hline NW & B & 0.0000 & 0.0009 & 0.0001 & 0.0000 & 0.0000 & 0.0000 \\
\hline NNW & B & 0.0000 & 0.0010 & 0.0000 & 0.0000 & 0.0000 & 0.0000 \\
\hline $\mathbf{N}$ & c & 0.0000 & 0.0017 & 0.0007 & 0.0000 & 0.0000 & 0.0000 \\
\hline NNE & C & 0.0000 & 0.0012 & 0.0002 & 0.0000 & 0.0000 & 0.0000 \\
\hline NE & C & 0.0002 & 0.0033 & 0.0016 & 0.0000 & 0.0000 & 0.0000 \\
\hline ENE & c & 0.0000 & 0.0018 & 0.0010 & 0.0000 & 0.0000 & 0.0000 \\
\hline$E$ & $c$ & 0.0005 & 0.0033 & 0.0021 & 0.0000 & 0.0000 & 0.0000 \\
\hline ESE & $c$ & 0.0000 & 0.0018 & 0.0020 & 0.0000 & 0.0000 & 0.0000 \\
\hline SE & $c$ & 0.0001 & 0.0011 & 0.0006 & 0.0000 & 0.0000 & 0.0000 \\
\hline SSE & c & 0.0001 & 0.0016 & 0.0002 & 0.0000 & 0.0000 & 0.0000 \\
\hline$s$ & C & 0.0000 & 0.0027 & 0.0015 & 0.0000 & 0.0000 & 0.0000 \\
\hline SSW & C & 0.0000 & 0.0012 & 0.0051 & 0.0001 & 0.0000 & 0.0000 \\
\hline SW & c & 0.0000 & 0.0010 & 0.0022 & 0.0000 & 0.0000 & 0.0000 \\
\hline WSW & $c$ & 0.0001 & 0.0013 & 0.0009 & 0.0000 & 0.0000 & 0.0000 \\
\hline$w$ & C & 0.0001 & 0.0017 & 0.0006 & 0.0000 & 0.0000 & 0.0000 \\
\hline WNW & c & 0.0001 & 0.0016 & 0.0029 & 0.0002 & 0.0000 & 0.0000 \\
\hline MN & c & 0.0000 & 0.0033 & 0.0139 & 0.0013 & 0.0000 & 0.0000 \\
\hline NMW & C & 0.0004 & 0.0033 & 0.0083 & 0.0012 & 0.0000 & 0.0000 \\
\hline $\mathbf{N}$ & D & 0.0022 & 0.0104 & 0.0193 & 0.0051 & 0.0000 & 0.0000 \\
\hline NNE & $p$ & 0.0012 & 0.0047 & 0.0163 & 0.0002 & 0.0000 & 0.0000 \\
\hline NE & D & 0.0010 & 0.0075 & 0.0377 & 0.0192 & 0.0004 & 0.0000 \\
\hline
\end{tabular}


Table 1-1 (Continued). Pinellas Plant Meteorological Station Wind Frequency

Distribution, 1994, by Wind Speed, Stability Class, and Origin

\begin{tabular}{|c|c|c|c|c|c|c|c|}
\hline \multirow{2}{*}{$\begin{array}{l}\text { MND } \\
\text { ORIGIN }\end{array}$} & \multirow{2}{*}{$\begin{array}{l}\text { PASQUILL-GIFFORD } \\
\text { STABILITY } \\
\text { CLASS } \\
\end{array}$} & \multicolumn{6}{|c|}{ WINO SPEEOS IN KNOTS } \\
\hline & & $1-3$ & 46 & $7-10$ & $11-16$ & $17-21$ & 221 \\
\hline ENE & 0 & 0.0017 & 0.0119 & 0.0284 & 0.0097 & 0.0007 & 0.0000 \\
\hline$E$ & D & 0.0036 & 0.0164 & 0.0323 & 0.0098 & 0.0000 & 0.0000 \\
\hline ESE & D & 0.0013 & 0.0075 & 0.0155 & 0.0086 & 0.0001 & 0.0000 \\
\hline SE & D & 0.0010 & 0.0110 & 0.0115 & 0.0039 & 0.0000 & 0.0000 \\
\hline SSE & D & 0.0013 & 0.0086 & 0.0111 & 0.0042 & 0.0001 & 0.0000 \\
\hline $\mathbf{s}$ & D & 0.0023 & 0.0086 & 0.0172 & 0.0147 & 0.0038 & 0.0002 \\
\hline ssw & $D$ & 0.0009 & 0.0098 & 0.0179 & 0.0108 & 0.0001 & 0.0000 \\
\hline sw & 0 & 0.0005 & 0.0067 & 0.0121 & 0.0036 & 0.0000 & 0.0000 \\
\hline WSW & D & 0.0002 & 0.0037 & 0.0099 & 0.0033 & 0.0000 & 0.0000 \\
\hline$w$ & $D$ & 0.0004 & 0.0009 & 0.0187 & 0.0059 & 0.0007 & 0.0000 \\
\hline mw & $D$ & 0.0007 & 0.0144 & 0.0179 & 0.0022 & 0.0012 & 0.0000 \\
\hline $\mathbf{M W}$ & D & 0.0012 & 0.0141 & 0.0135 & 0.0034 & 0.0010 & 0.0000 \\
\hline NMW & D & 0.0009 & 0.0109 & 0.0120 & 0.0056 & 0.0000 & 0.0000 \\
\hline$\underline{N}$ & $E$ & 0.0015 & 0.0150 & 0.0006 & 0.0000 & 0.0000 & 0.0000 \\
\hline NNE & $E$ & 0.0006 & 0.0088 & 0.0031 & 0.0000 & 0.0000 & 0.0000 \\
\hline NE & $E$ & 0.0007 & 0.0077 & 0.0007 & 0.0000 & 0.0000 & 0.0000 \\
\hline ENE & $\underline{E}$ & 0.0021 & 0.0158 & 0.0023 & 0.0000 & 0.0000 & 0.0000 \\
\hline$E$ & $E$ & 0.0045 & 0.0169 & 0.0017 & 0.0000 & 0.0000 & 0.0000 \\
\hline ESE & $E$ & 0.0043 & 0.0141 & 0.0038 & 0.0000 & 0.0000 & 0.0000 \\
\hline SE & $E$ & 0.0040 & 0.0132 & 0.0013 & 0.0000 & 0.0000 & 0.0000 \\
\hline SSE & $E$ & 0.0021 & 0.0071 & 0.0013 & 0.0000 & 0.0000 & 0.0000 \\
\hline$s$ & $E$ & 0.0020 & 0.0061 & 0.0004 & 0.0000 & 0.0000 & 0.0000 \\
\hline SSW & $E$ & 0.0009 & 0.0012 & 0.0001 & $0.0000^{\circ}$ & 0.0000 & 0.0000 \\
\hline sw & E & 0.0010 & 0.0028 & 0.0001 & 0.0000 & 0.0000 & 0.0000 \\
\hline wsw & $E$ & 0.0004 & 0.0044 & 0.0013 & 0.0000 & 0.0000 & 0.0000 \\
\hline$w$ & $E$ & 0.0011 & 0.0080 & 0.0009 & 0.0000 & 0.0000 & 0.0000 \\
\hline WNW & $E$ & 0.0007 & 0.004 & 0.0000 & 00000 & 0.0000 & 0.0000 \\
\hline MN & $E$ & 0.0020 & 0.0016 & 0.0000 & 0.0000 & 0.0000 & 0.0000 \\
\hline Now & $E$ & 0.0026 & 0.0036 & 0.0000 & 0.0000 & 0.0000 & 0.0000 \\
\hline $\mathbf{N}$ & $F$ & 0.0099 & 0.0002 & 0.0000 & 0.0000 & 0.0000 & 0.0000 \\
\hline NNE & $F$ & 0.0089 & 0.0044 & 0.0000 & 0.0000 & 0.0000 & 0.0000 \\
\hline NE. & $F$ & 0.0092 & 0.0029 & 0.0000 & 0.0000 & 0.0000 & 0.0000 \\
\hline ENE & $\boldsymbol{E}$ & 0.0083 & 0.0049 & 0.0000 & 0.0000 & 0.0000 & 0.0000 \\
\hline$E$ & $F$ & 0.0108 & 0.0036 & 0.0000 & 0.0000 & 0.0000 & 0.0000 \\
\hline ESE & $F$ & 0.0061 & 0.0017 & 0.0000 & 0.0000 & 0.0000 & 0.0000 \\
\hline SE & $F$ & 0.0048 & 0.0007 & 0.0000 & 0.0000 & 0.0000 & 0.0000 \\
\hline SSE & $F$ & 0.0023 & 0.0002 & 0.0000 & 0.0000 & 0.0000 & 0.0000 \\
\hline$s$ & $F$ & 0.0028 & 0.0007 & 0.0000 & 0.0000 & 0.0000 & 0.0000 \\
\hline SSW & $F$ & 0.0024 & 0.0007 & 0.0000 & 0.0000 & 0.0000 & 0.0000 \\
\hline sw & $F$ & 0.0022 & 0.0009 & 0.0000 & 0.0000 & 0.0000 & 0.0000 \\
\hline WSW & $F$ & 0.0032 & 0.0012 & 0.0000 & 0.0000 & 0.0000 & 0.0000 \\
\hline$w$ & $F$ & 0.0059 & 0.0020 & 0.0000 & 0.0000 & 0.0000 & 0.0000 \\
\hline WhW & $F$ & 0.0032 & 0.0011 & 0.0000 & 0.0000 & 0.0000 & 0.0000 \\
\hline NW & $F$ & 0.0043 & 0.0002 & 0.0000 & 0.0000 & 0.0000 & 0.0000 \\
\hline Nun & $F$ & 0.0042 & 0.0006 & 0.0000 & 0.0000 & 0.0000 & 0.0000 \\
\hline TOTAL & $\ldots$ & 0.14528 & 0.3716 & 0.35534 & 0.11819 & 0.00818 & 0.00024 \\
\hline
\end{tabular}




\begin{tabular}{|c|c|c|c|c|c|c|c|c|c|c|c|c|c|c|c|c|}
\hline & \multicolumn{5}{|c|}{ PO METER TOWEA } & \multicolumn{5}{|c|}{12.6 METER TOWER } & \multicolumn{5}{|c|}{2 METER LEVEL } \\
\hline & & Ws & $S T$ & vs & ST & $\mathbf{T}$ & Ws & st & Vs & VSST & $\mathbf{T}$ & $T$ & RH & PRESS & SOLAR & PREC \\
\hline JAN & $\begin{array}{l}\operatorname{Max} \\
\text { AVo } \\
\text { MIN }\end{array}$ & $\begin{array}{r}11.0 \\
4.6 \\
0.5\end{array}$ & $\begin{array}{r}01.1 \\
.10 .7 \\
2.4\end{array}$ & $\begin{array}{l}1.0 \\
0.2 \\
0.0\end{array}$ & $\begin{array}{l}1.3 \\
0.5 \\
0.0\end{array}$ & $\begin{array}{r}24,0 \\
14.7 \\
4.3\end{array}$ & $\begin{array}{r}0.8 \\
3.0 \\
. \quad 0.4\end{array}$ & $\begin{array}{r}65.0 \\
13.1 \\
4.1\end{array}$ & $\begin{array}{l}0.0 \\
0.1 \\
0.8\end{array}$ & $\begin{array}{l}1.1 \\
0.4 \\
0.0\end{array}$ & $\begin{array}{r}24.0 \\
13.3 \\
4.7\end{array}$ & $\begin{array}{r}28.8 \\
15.0 \\
4.8\end{array}$ & $\begin{array}{l}07.9 \\
77.0 \\
40.4\end{array}$ & $\begin{array}{l}1031 \\
1020 \\
1005\end{array}$ & $\begin{array}{r}91000 \\
2030\end{array}$ & 4.34 \\
\hline FEB & $\begin{array}{l}\text { MAX } \\
\text { AVO } \\
\text { MIN }\end{array}$ & $\begin{array}{r}11.1 \\
4.8 \\
1.1\end{array}$ & $\begin{array}{r}02.0 \\
10.5 \\
1.0\end{array}$ & $\begin{array}{r}1.0 \\
0.2 \\
0.2\end{array}$ & $\begin{array}{l}1.3 \\
0.5 \\
0.0\end{array}$ & $\begin{array}{r}20.2 \\
17.6 \\
4.5\end{array}$ & $\begin{array}{l}0.6 \\
3.8 \\
0.4\end{array}$ & $\begin{array}{r}07.2 \\
12.7 \\
5.7\end{array}$ & $\begin{array}{c}0.7 \\
0.1 \\
-0.2\end{array}$ & $\begin{array}{l}1.0 \\
0.4 \\
0.0\end{array}$ & $\begin{array}{r}28.7 \\
18.2 \\
4.8\end{array}$ & $\begin{array}{r}27.4 \\
10.4 \\
4.0\end{array}$ & $\begin{array}{l}00.4 \\
75.0 \\
27.7\end{array}$ & $\begin{array}{l}1020 \\
1010 \\
1010\end{array}$ & $\begin{array}{r}100517 \\
3800\end{array}$ & 0.30 \\
\hline MAR & $\begin{array}{l}\operatorname{Max} \\
\text { Avo } \\
\text { MIN }\end{array}$ & $\begin{array}{r}12.7 \\
4.7 \\
0.9\end{array}$ & $\begin{array}{r}50.0 \\
10.7 \\
2.3\end{array}$ & $\begin{array}{l}1.2 \\
0.1 \\
0.6\end{array}$ & $\begin{array}{l}1.4 \\
0.5 \\
0.0\end{array}$ & $\begin{array}{r}27.0 \\
18.0 \\
7.0\end{array}$ & $\begin{array}{r}11.0 \\
3.0 \\
0.3\end{array}$ & $\begin{array}{r}72.0 \\
13.0 \\
5.0\end{array}$ & $\begin{array}{r}0.0 \\
0.1 \\
0.5\end{array}$ & $\begin{array}{l}1.3 \\
0.4 \\
0.0\end{array}$ & $\begin{array}{r}28.4 \\
10.3 \\
7.4\end{array}$ & $\begin{array}{r}20.2 \\
10.5 \\
7.5\end{array}$ & $\begin{array}{l}98.1 \\
73.8 \\
25.0\end{array}$ & $\begin{array}{l}1027 \\
1010 \\
1005\end{array}$ & $\begin{array}{r}151002 \\
4871\end{array}$ & 2.07 \\
\hline APR & $\begin{array}{l}\text { MAX } \\
\text { AVO } \\
\text { MIN }\end{array}$ & $\begin{array}{l}0.0 \\
4.2 \\
0.3\end{array}$ & $\begin{array}{r}60.4 \\
11.0 \\
1.7\end{array}$ & $\begin{array}{l}0.8 \\
0.2 \\
0.3\end{array}$ & $\begin{array}{l}1.0 \\
0.4 \\
0.0\end{array}$ & $\begin{array}{l}20.0 \\
22.5 \\
12.7\end{array}$ & $\begin{array}{l}7.7 \\
3.8 \\
0.4\end{array}$ & $\begin{array}{r}70.1 \\
14.3 \\
4.2\end{array}$ & $\begin{array}{r}0.0 \\
0.2 \\
-0.3\end{array}$ & $\begin{array}{l}0.0 \\
0.4 \\
0.0\end{array}$ & \begin{tabular}{l|}
30.4 \\
23.0 \\
11.2
\end{tabular} & $\begin{array}{l}31.0 \\
23.5 \\
10.0\end{array}$ & $\begin{array}{l}97.2 \\
74.4 \\
30.1\end{array}$ & $\begin{array}{l}1023 \\
1017 \\
1010\end{array}$ & $\begin{array}{r}103071 \\
\text { suse }\end{array}$ & 1.81 \\
\hline mar & $\begin{array}{l}\operatorname{Max} \\
\text { AVO } \\
\text { MIN }\end{array}$ & $\begin{array}{l}0.1 \\
3.8 \\
0.3\end{array}$ & $\begin{array}{r}20.1 \\
14.0 \\
2.3\end{array}$ & $\begin{array}{l}0.0 \\
0.0 \\
-0.4\end{array}$ & $\begin{array}{l}1.0 \\
0.4 \\
0.0\end{array}$ & $\begin{array}{l}30.0 \\
24.6 \\
16.5\end{array}$ & $\begin{array}{l}7.7 \\
2.0 \\
0.4\end{array}$ & $\begin{array}{r}-8.4 \\
10.0 \\
4.2\end{array}$ & $\begin{array}{l}0.4 \\
0.0 \\
0.4\end{array}$ & $\begin{array}{l}0.0 \\
0.3 \\
0.0\end{array}$ & $\begin{array}{l}31.5 \\
24.9 \\
10.1\end{array}$ & $\begin{array}{l}32.5 \\
25.4 \\
15.0\end{array}$ & $\begin{array}{l}94.4 \\
72.1 \\
90.7\end{array}$ & $\begin{array}{l}1020 \\
1014 \\
1003\end{array}$ & $\begin{array}{r}187470 \\
\text { cones }\end{array}$ & 0.15 \\
\hline JUN & $\begin{array}{l}\operatorname{Max} \\
\text { AVo } \\
\text { MIN }\end{array}$ & $\begin{array}{l}0.0 \\
3.3 \\
0.5\end{array}$ & $\begin{array}{r}r 3.0 \\
14.7 \\
3.0\end{array}$ & $\begin{array}{l}0.6 \\
0.0 \\
0.4\end{array}$ & $\begin{array}{l}1.0 \\
0.4 \\
0.0\end{array}$ & $\begin{array}{l}32.2 \\
20.8 \\
10.8\end{array}$ & $\begin{array}{l}7.3 \\
2.0 \\
0.5\end{array}$ & $\begin{array}{r}05.3 \\
17.3 \\
4.2\end{array}$ & $\begin{array}{l}0.5 \\
0.0 \\
0.5\end{array}$ & $\begin{array}{l}0.8 \\
0.3 \\
0.0\end{array}$ & \begin{tabular}{l|}
22.0 \\
27.2 \\
21.0
\end{tabular} & $\begin{array}{l}33.7 \\
27.6 \\
23.3\end{array}$ & $\begin{array}{l}94.0 \\
77.2 \\
48.0\end{array}$ & $\begin{array}{l}1020 \\
1010 \\
1012\end{array}$ & $\begin{array}{r}102007 \\
5420\end{array}$ & 3.33 \\
\hline JUL & $\underset{\text { MIN }}{\max }$ & $\begin{array}{l}7.8 \\
3.1 \\
0.8\end{array}$ & $\begin{array}{r}74.8 \\
15.0 \\
4.8\end{array}$ & $\begin{array}{l}0.0 \\
0.1 \\
0.9\end{array}$ & $\begin{array}{l}1.0 \\
0.4 \\
0.0\end{array}$ & $\begin{array}{l}32.5 \\
20.6 \\
18.4\end{array}$ & $\begin{array}{l}6.8 \\
2.6 \\
0.8\end{array}$ & $\begin{array}{r}75.1 \\
17.0 \\
6.1\end{array}$ & $\begin{array}{l}0.1 \\
0.1 \\
0.3\end{array}$ & $\begin{array}{l}0.8 \\
0.3 \\
0.0\end{array}$ & $\begin{array}{l}22.0 \\
27.0 \\
20.1\end{array}$ & $\begin{array}{l}23.0 \\
27.4 \\
20.5\end{array}$ & $\begin{array}{l}\infty 6.8 \\
77.8 \\
48.7\end{array}$ & $\begin{array}{l}1022 \\
1018 \\
1012\end{array}$ & $\begin{array}{r}152020 \\
4023\end{array}$ & 0.07 \\
\hline Auo & $\begin{array}{l}\text { MAX } \\
\text { AVQ } \\
\text { MIN }\end{array}$ & $\begin{array}{l}0.8 \\
3.3 \\
0.4\end{array}$ & $\begin{array}{r}01.5 \\
14.0 \\
3.4\end{array}$ & $\begin{array}{l}0.0 \\
0.1 \\
0.4\end{array}$ & $\begin{array}{l}1.2 \\
0.4 \\
0.0\end{array}$ & $\begin{array}{l}32.0 \\
20.1 \\
18.6\end{array}$ & $\begin{array}{l}7.7 \\
2.6 \\
0.9\end{array}$ & $\begin{array}{c}30.1 \\
17.1 \\
8.8\end{array}$ & $\begin{array}{l}0.0 \\
0.1 \\
0.3\end{array}$ & $\begin{array}{l}1.0 \\
0.2 \\
0.0\end{array}$ & $\begin{array}{l}32.0 \\
20.5 \\
21.7\end{array}$ & $\begin{array}{l}20.3 \\
26.7 \\
22.3\end{array}$ & $\begin{array}{l}\infty .7 \\
61.6 \\
51.3\end{array}$ & $\begin{array}{l}1020 \\
1016 \\
1012\end{array}$ & $\begin{array}{r}130001 \\
4460\end{array}$ & 7.30 \\
\hline SEP & $\begin{array}{l}\max \\
\text { Avo } \\
\text { MIN }\end{array}$ & $\begin{array}{l}0.7 \\
3.2 \\
0.2\end{array}$ & $\begin{array}{r}40.5 \\
15.3 \\
4.3\end{array}$ & $\begin{array}{l}0.0 \\
0.9 \\
0.2\end{array}$ & $\begin{array}{l}0.0 \\
0.4 \\
0.0\end{array}$ & $\begin{array}{l}\mathbf{3 0 . 7} \\
27.0 \\
22.1\end{array}$ & $\begin{array}{l}7.4 \\
2.7 \\
0.3\end{array}$ & $\begin{array}{r}33.4 \\
18.1 \\
7.4\end{array}$ & $\begin{array}{r}0.7 \\
0.1 \\
-0.2\end{array}$ & $\begin{array}{l}0.7 \\
0.9 \\
0.0\end{array}$ & $\begin{array}{l}30.9 \\
27.1 \\
20.3\end{array}$ & $\begin{array}{l}31.6 \\
27.2 \\
23.5\end{array}$ & $\begin{array}{l}05.3 \\
78.3 \\
57.7\end{array}$ & $\begin{array}{l}1020 \\
1017 \\
1011\end{array}$ & $\begin{array}{r}200560 \\
005\end{array}$ & 0.00 \\
\hline OCT & $\begin{array}{l}\operatorname{Max} \\
\text { AVO } \\
\text { MIN }\end{array}$ & $\begin{array}{r}10.4 \\
2.5 \\
0.2\end{array}$ & $\begin{array}{r}70.0 \\
11.8 \\
1.8\end{array}$ & $\begin{array}{l}0.8 \\
0.2 \\
0.3\end{array}$ & $\begin{array}{l}3.4 \\
0.4 \\
0.0\end{array}$ & $\begin{array}{r}30.7 \\
23.4 \\
0.1\end{array}$ & $\begin{array}{l}8.0 \\
3.1 \\
0.3\end{array}$ & $\begin{array}{r}76.0 \\
14.0 \\
4.2\end{array}$ & $\begin{array}{l}1.2 \\
0.1 \\
0.2\end{array}$ & $\begin{array}{l}4.1 \\
0.3 \\
0.0\end{array}$ & $\begin{array}{l}30.8 \\
23.7 \\
12.8\end{array}$ & $\begin{array}{l}31.4 \\
23.8 \\
17.7\end{array}$ & $\begin{array}{r}\infty .5 \\
0.3 \\
-\infty .3\end{array}$ & $\begin{array}{l}1010 \\
1013 \\
1005\end{array}$ & $\begin{array}{r}1235035 \\
3005\end{array}$ & 0.22 \\
\hline NOV & $\begin{array}{l}\operatorname{MAX} \\
\text { AVG } \\
\text { MIN }\end{array}$ & $\begin{array}{r}11.2 \\
4.4 \\
0.8\end{array}$ & $\begin{array}{r}55.4 \\
10.9 \\
1.0\end{array}$ & $\begin{array}{r}0.6 \\
0.2 \\
0.2\end{array}$ & $\begin{array}{l}1.1 \\
0.4 \\
0.0\end{array}$ & $\begin{array}{r}20.4 \\
21.4 \\
0.0\end{array}$ & $\begin{array}{l}0.1 \\
3.4 \\
0.4\end{array}$ & $\begin{array}{r}52.0 \\
13.0 \\
3.0\end{array}$ & $\begin{array}{l}0.5 \\
0.1 \\
0.3\end{array}$ & $\begin{array}{l}1.0 \\
0.3 \\
0.0\end{array}$ & $\begin{array}{r}20.7 \\
21.0 \\
0.0\end{array}$ & $\begin{array}{r}20.1 \\
21.0 \\
0.0\end{array}$ & $\begin{array}{l}08.4 \\
78.7 \\
37.2\end{array}$ & $\begin{array}{l}1025 \\
1010 \\
1000\end{array}$ & $\begin{array}{r}100020 \\
30034\end{array}$ & 0.31 \\
\hline DEC & $\begin{array}{l}\text { MAX } \\
\text { AVO } \\
\text { MIN }\end{array}$ & $\begin{array}{l}0.0 \\
4.1 \\
0.7 \\
\end{array}$ & $\begin{array}{r}71.4 \\
10.0 \\
2.3 \\
\end{array}$ & $\begin{array}{l}0.5 \\
0.1 \\
0.3 \\
\end{array}$ & $\begin{array}{l}1.1 \\
0.4 \\
0.0 \\
\end{array}$ & $\begin{array}{r}27.0 \\
17.9 \\
7.0 \\
\end{array}$ & $\begin{array}{l}7.0 \\
3.1 \\
0.0 \\
\end{array}$ & $\begin{array}{r}68.6 \\
13.5 \\
4.5 \\
\end{array}$ & $\begin{array}{r}0.5 \\
0.0 \\
0.4 \\
\end{array}$ & $\begin{array}{l}1.2 \\
0.3 \\
0.0 \\
\end{array}$ & \begin{tabular}{r|}
28.0 \\
17.3 \\
0.0 \\
\end{tabular} & $\begin{array}{r}26.8 \\
17.6 \\
7.6 \\
\end{array}$ & $\begin{array}{l}\infty 0.3 \\
80.3 \\
30.3 \\
\end{array}$ & $\begin{array}{l}1023 \\
1017 \\
1008 \\
\end{array}$ & $\begin{array}{l}20100 \\
2010\end{array}$ & 3.00 \\
\hline
\end{tabular}

WS WINO SPEED, METERSYSEC

ST STO DEVIATION, WIND OIRECTION

VS VERTICAL WIND SPEEO

AH REL. HUMIOTY. *
PRES BAROMETRK PRESSURE, MBAR

SOLAR INSOLATON. MATTSISO. METER)

PREC PRECIPTIATION, INCHES 
The potential for hurricanes exists in the Tampa Bay area. Based on records from 1866 through 1981, the relative frequency of a hurricane passing within an 80 -kilometer ( 50 -mile) radius of the plant site is one in every 8.6 years.

Hurricanes and tropical storms contribute 25 to 30 percent of the area's annual rainfall. The peak hurricane frequency occurs in September and October, with 3.4 storms per decade. The hurricane frequencies for June, July, and August are 0.4, 0.7 , and 2.1 per decade, respectively. In general, tropical storm and hurricane frequency are the same. Hurricanes have winds over 74 miles per hour ( $\mathrm{mph}$ ), while tropical storms have peak winds from 39 to $73 \mathrm{mph}$. The hurricane frequency drops from 3.4 storms per decade in October to 0.3 storms per decade in November.

Tidal flooding from hurricanes causes the greatest amount of damage. The Army Corps of Engineers determined the maximum anticipated high tide to be at approximately 4.3 meters (14 feet) above Mean Sea Level (MSL) based on a design hurricane. Since the plant is several miles inland and has a minimum floor height of 5.6 meters (18.5 feet) above sea level, no damage is expected from tidal flooding. Flood plain maps depicting flooding expected from a "100-year storm" show that the plant is not in a flood-prone zone.

The probability of a tornado striking any point in the Pinellas Plant site is $4.3 \times 10^{-4}$ per year [Ref. 5]. On October 3, 1992, a series of tornados swept through Pinellas County causing damage and fatalities. The nearest tornado struck about two miles east of the plant. Damage was limited to off-site monitoring stations and was repaired quickly. There were no other environmental damages or impacts to the plant. Waterspouts moving ashore typically dissipate within a few blocks after reaching land, and the potential for damage to the plant is small.

\subsection{Seismology}

The earliest recorded and the most severe earthquake occurred on January 12, 1879 near St. Augustine, Florida [Ref. 6]. The tremors lasted 10 minutes and covered an area of 65,000 square kilometers, or 25,000 square miles, from Savannah, Georgia in the north to Daytona Beach, Florida in the south. The only damage reported was in St. Augustine, where some residents were showered with ceiling plaster. Several events of less intensity have been reported since then. Smaller events probably occurred and escaped detection because of the distance to the nearest seismic station, and the tendency of the residents to identify these with the space shuttle, rockets, or airplanes. There is no reasonable expectancy for damaging earthquakes at the plant. The seismic risk map of the United States shows Central and Southern Florida in Zone 0 (Figure 1-6), a "no damage" zone. 


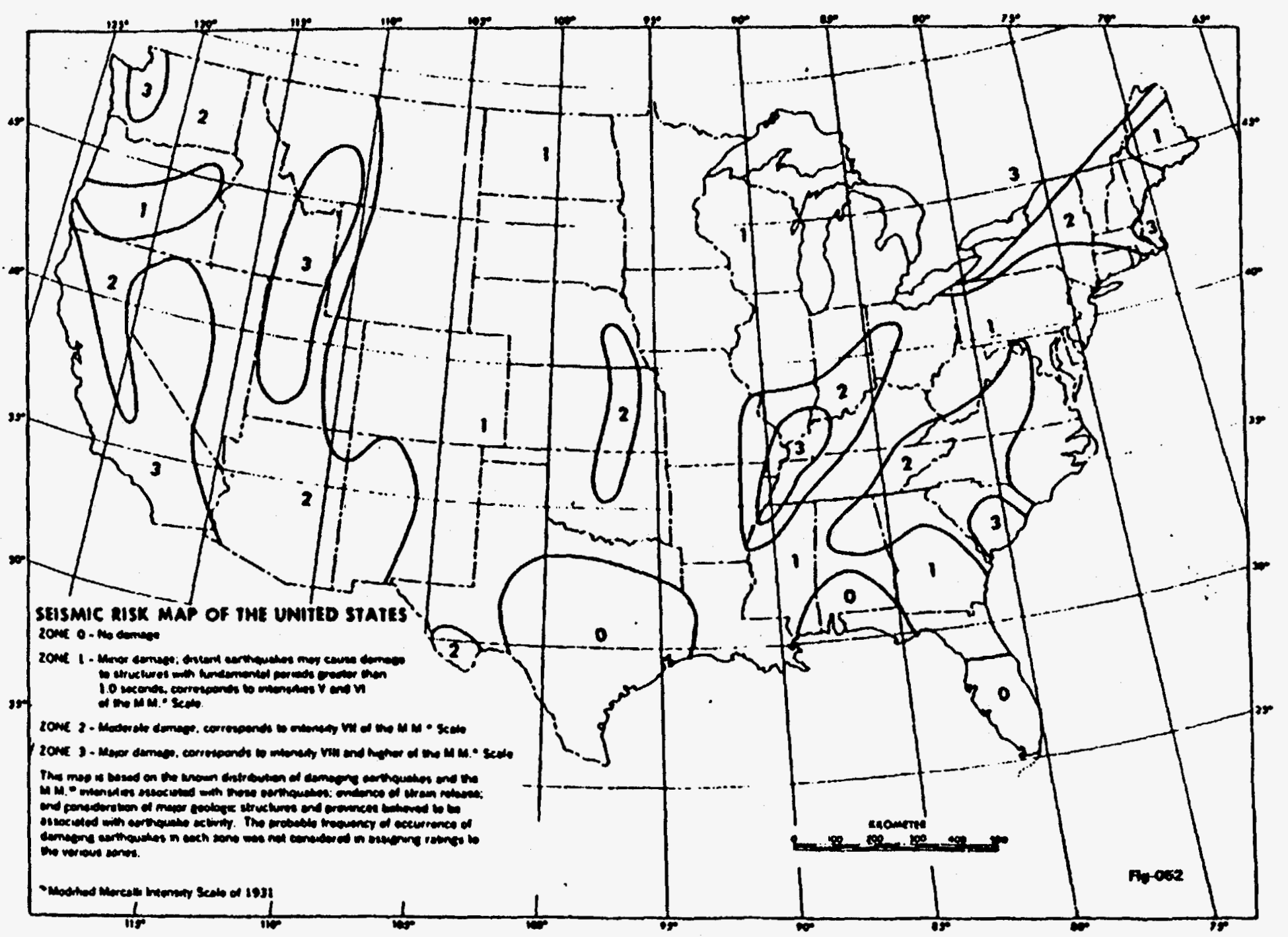

Reprinted from Selswle Risk Studles in the United States, by S. T. Algermissen, Proceedings of the Fourth World Conference on Earthquake Englneering, vol. 1, pp. 14-27, Sant1ago, Ch1le, 1969.

Figure 1-6. Seismic Risk Map of the United States 


\subsection{Land Use}

The Pinellas Plant site and the adjacent properties to the east and west are zoned for heavy and light industrial use, respectively. Within a 1-kilometer radius to the north, northeast, and southwest are residential areas zoned at a maximum of 10 units per acre. A golf course to the south of the plant site provides a 1-kilometer-wide buffer to the nearest residential area. The East and West Ponds (Figure 1-7) are designated as wetlands by the U. S. Department of the Interior, Fish and Wildlife Service's National Wetlands Inventory [Ref. 7]. No historic or archaeological sites are located on the plant site. 
'py 1ә4요

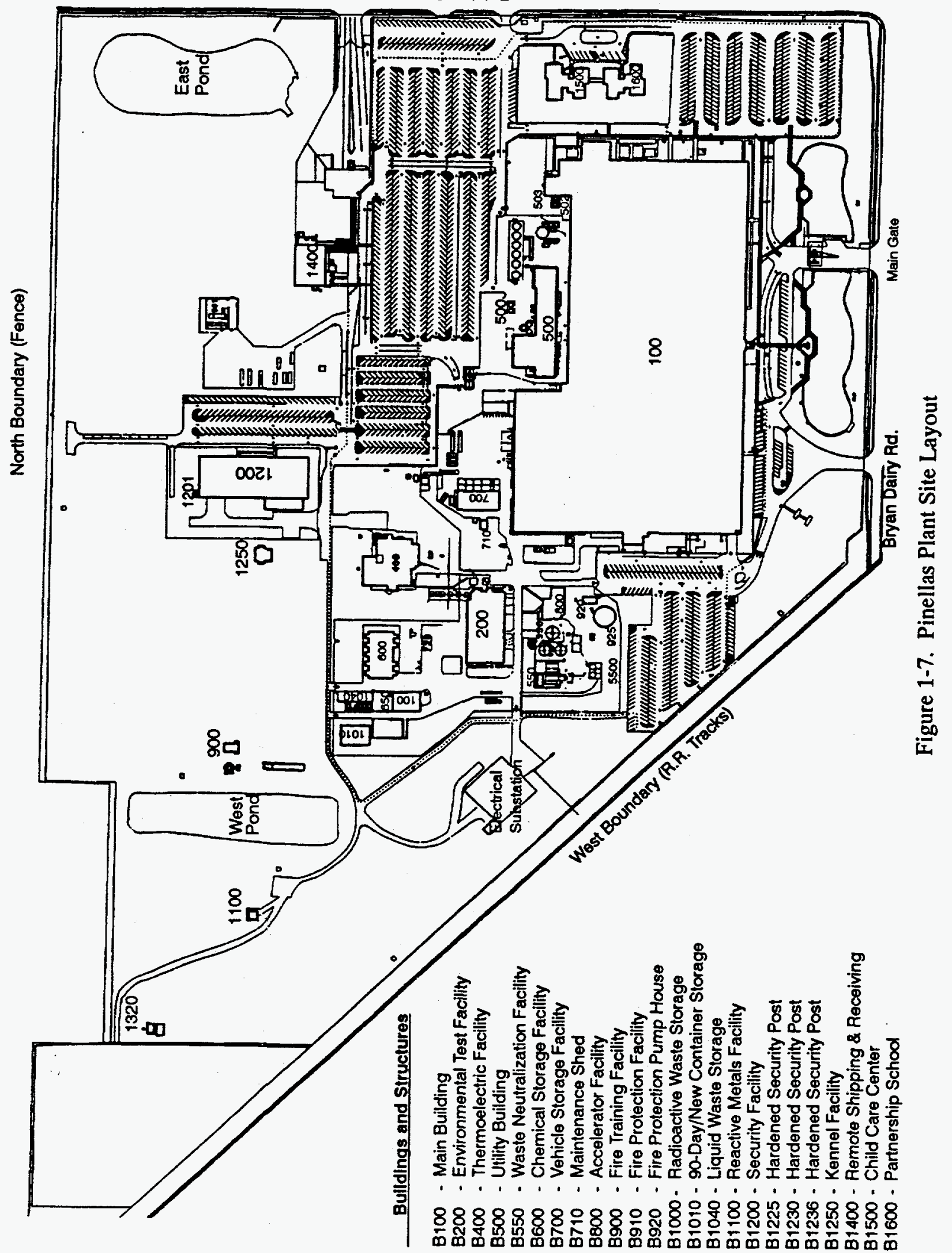




\subsection{Population}

Pinellas County remains the most densely populated county in the state, with over $75 \%$ of the total land area dedicated to urbanized use. Table 1-3 is a brief table of statistics on Pinellas County's population based on the decennial U. S. census tables for the years the Pinellas Plant has operated.

Table 1-3. Pinellas County Population Statistics

\begin{tabular}{|c|c|c|}
\hline Year & Population & $\begin{array}{l}\text { Average Population } \\
\text { Density, Persons/Acre }\end{array}$ \\
\hline $1950^{1}$ & 159,249 & 0.89 \\
\hline $1956^{*}$ & 250,000 & 1.4 \\
\hline $1960^{1}$ & 374,665 & 2.1 \\
\hline $1970^{1}$ & 522,329 & 2.9 \\
\hline $1980^{1}$ & 728,531 & 4.1 \\
\hline $1990^{1}$ & 851,659 & 4.8 \\
\hline $1992^{2}$ & $908,000^{3}$ & 5.1 \\
\hline \multicolumn{3}{|c|}{$\begin{array}{l}\text { Year Pinellas Plant began operations (population estimated) } \\
\text { From U. S. Census data } \\
\text { Estimated } \\
864,000 \text { Permanent, } 44,000 \text { Seasonal }\end{array}$} \\
\hline
\end{tabular}

In 1992, the Pinellas Plant conducted a study to determine the distribution of the population within 50 miles of the plant site. Based on the study, the greatest population densities are in the northwest and southeast quadrants and at a distance greater than 10 kilometers. Over 2.5 million people reside within this 50 -mile radius. This data was obtained from the $1990 \mathrm{U}$. S. Census and is presented in Table 1-4.

The estimated 1992 resident population was 908,000 . Of this total, 864,000 are permanent residents, and 44,000 , or $5 \%$, are considered seasonal residents. The seasonal variations in population generally peak during March, with a corresponding trough occurring in late June. This cyclic pattern has been repeatedly demonstrated through the years. The estimated 1992 population density is 3.6 times greater than it was when the plant started operations in 1957. 
Table 1-4. 1990 Population by Sector-Segment

\begin{tabular}{|c|c|c|c|c|c|c|c|c|c|}
\hline \multicolumn{10}{|c|}{1990 Populations by Sector-Segment Cumulative Totals } \\
\hline \multirow[b]{2}{*}{ Direction } & \multicolumn{9}{|c|}{ Distance (Mlles) } \\
\hline & 0.2 & 0.3 & $0-4$ & 0.5 & $0-10$ & $0-20$ & $0-30$ & $0-40$ & 0.50 \\
\hline $\mathbf{N}$ & 2,421 & 8,250 & 13,814 & 20,577 & 77,079 & 184,807 & 295,815 & 342,718 & 348.042 \\
\hline NNE & 3,806 & 8,034 & 12,428 & 16,549 & 41,695 & 76,051 & 91,591 & 115,686 & 184,974 \\
\hline NE & 2,594 & 4,381 & 8,664 & 10,191 & 10,196 & 123,547 & 236,574 & 256,638 & 308,734 \\
\hline ENE & 1,790 & 2,389 & 3,285 & 4,505 & 5,922 & 146,372 & 331,993 & 382,782 & 452,597 \\
\hline E & 2,558 & 3,703 & 4,534 & 5,025 & 17,582 & 70,487 & 153,901 & 189,240 & 239,819 \\
\hline ESE & 1,900 & 7,364 & 14,304 & 18,755 & 67,698 & 70,230 & 103,531 & 106,379 & 106,919 \\
\hline $\mathbf{S E}$ & 1,818 & 5,341 & 11,052 & 16,633 & 87,174 & 106,883 & 120,460 & 123,815 & 126,122 \\
\hline SSE & 1,597 & 6,054 & 12,646 & 21,593 & 86,904 & 119,934 & 219,238 & 357,192 & 482,892 \\
\hline $\mathbf{s}$ & 2,324 & 3,842 & 9,670 & 15,549 & 46,337 & 53,809 & 66,439 & 69,142 & 69,142 \\
\hline SSW & 4,317 & 7,487 & 9,964 & 14,678 & 21,208 & 21,208 & 21,208 & 21,208 & 21,208 \\
\hline sw & 2,288 & 3,879 & 9,630 & 14,867 & 19,559 & 19,559 & 19,559 & 19,559 & 19,559 \\
\hline WSW & 1,575 & 4,992 & 11,655 & 18,316 & 24,490 & 24,490 & 24,490 & 24,490 & 24,490 \\
\hline W & 2,371 & 7,525 & 10,562 & 17,551 & 26,603 & 26,603 & 26,603 & 26,603 & 26,603 \\
\hline WNW & 2,140 & 7,137 & 12,514 & 21,260 & 28,300 & 28,300 & 28,300 & 28,300 & 28,300 \\
\hline $\mathrm{NW}$ & 1,553 & 5,068 & 10,760 & 19,026 & 27,477 & 27,477 & 27,477 & 27,477 & 27,477 \\
\hline NNW & 1,013 & 4,459 & 10,404 & 18,298 & 60,032 & 62,991 & 62,991 & 62,991 & 62,991 \\
\hline Total & 36,065 & 89,905 & 165,886 & 253,373 & 648,256 & $1,162,748$ & $1,830,170$ & $2,154,220$ & $2,529,869$ \\
\hline
\end{tabular}

\subsection{Water}

Pinellas County is one of 16 Florida counties in the Southwest Florida Water Management District (SWFWMD). Over 95\% of the water used in this district was withdrawn from groundwater in the Floridan Aquifer. During 1994, the Pinellas Plant discharged approximately 70 million gallons of water to the Pinellas County Sewer System (PCSS). 
This page left blank intentionally. 


\subsection{Compliance Status}

In 1994, the Pinellas Plant operated within the allowable discharge limits for both radioactive and nonradioactive materials to the ambient air and water. The Hazardous Waste Facility Permit and the Industrial Wastewater Discharge Permit were both renewed during 1994 . The remaining sections of this compliance summary include compliance activities under specific regulations.

\subsubsection{Clean Air Act}

\section{Radiological Emissions}

The 1994 Radionuclide Air Emissions Annual Report will be submitted to the EPA in June 1995. The report concluded that the effective dose equivalent to the most exposed individual of the public was 5.65E-03 $\mathrm{mrem} / \mathrm{yr}$. This is well below the $10 \mathrm{mrem} / \mathrm{yr}$ EPA standard [Ref. 8]. CAP88-PC, an EPA-approved computer code, was used to estimate the effective dose equivalent.

The Pinellas Plant annually validates continuous monitoring by performing stack flowrate measurements. The plant measured the flowrate of the main stack in August 1994, and the flowrate of the laboratory stack was measured in December 1994. The laboratory stack measurements were comparable to 1993 measurements. The main stack flowrate increased by approximately 4,000 cubic feet/minute (CFM) due to a fan motor replacement in June 1994.

The 1994 Annual Radionuclide Emissions Minor Source Compliance modeling run was conducted in March 1995. It utilized the EPA-approved COMPLY computer model using a worst-case emission scenario of 822 curies of tritium and 100 curies of $\mathrm{Kr}-85$ released from the main radiological exhaust stack. This worst-case scenario assumed the Tritium Recovery System (TRS), an emission control device, was not operational resulting in the uncontrolled release of all the tritium processed in 1994. The TRS normally removes $99.9 \%$ of all tritium prior to discharge through the Building 100 main stack. The report documented that even under this "worst-case" simulation, the dose would be $5.1 \times 10^{-2} \mathrm{mrem} / \mathrm{yr}$, which is below the $0.1 \mathrm{mrem} / \mathrm{yr}$ standard [Ref. 9] for the effective dose equivalent to the most exposed individual. This confirms EPA's designation of the plant as a minor source for radionuclide emissions. The Pinellas Plant is therefore not required to continuously monitor the radiological exhaust 
stacks. As a best management practice and to provide assurances to the community, however, continuous monitoring and sampling are performed on all four radiological exhaust stacks, around the perimeter of the plant, and at locations in Pinellas, Hillsborough, and Manatee Counties.

\section{Nonradiological Air Emissions Permitting}

On February 4, 1994, the Florida Department of Environmental Protection (FDEP) issued a plantwide air emissions permit to the Pinellas Plant. This permit defines chemical air emissions limits for the plant. Plant emissions are restricted to 41.1 tons of Volatile Organic and Organic Compounds (VOC/OC), and the permit requires ongoing compliance to State of Florida No-Threat-Level (NTL) emissions concentrations for pollutants.

The Pinellas Plant provides routine updates to both Pinellas County Air Quality Division (PCAQD) and the FDEP to reflect changes in plant operations pursuant to air permit requirements. Routine meetings and discussions are conducted with the agencies, as necessary, to identify additional permit requirements invoked by the consolidation of plant activities and the commercialization of the Pinellas Plant which was facilitated by the cessation of the Defense Programs (DP) mission on September 30, 1994.

\section{Clean Air Act Amendments}

Regulation development from the Clean Air Act (CAA) amendments continued to impact the Pinellas Plant during 1994. The most significant impact was the identification of the Pinellas Plant as an EPA Title V source. The greatest impact of this designation will be a requirement to characterize the Pinellas Plant's actual and potential air emissions and to submit a Title $\mathrm{V}$ air emissions permit application.

The Pinellas Plant will also be required to demonstrate compliance to various NESHAP air emissions standards and other requirements of the CAA amendments. A representative summary of the standards applicable to the Pinellas Plant are identified in Table 2-1. 
Table 2-1. Clean Air Act Requirements with Significant Impacts at the Pinellas Plant

\begin{tabular}{|c|c|c|}
\hline Regulntion & Summary of Requirements & $\begin{array}{l}\text { Pinellas Plant Completed and } \\
\text { Planned A ctions }\end{array}$ \\
\hline $\begin{array}{l}\text { General Title V Air Permitting } \\
\text { Requirements. Clean Air Act as } \\
\text { adopted by FDEP Rule } 62- \\
213.100(19) \text {, Florida } \\
\text { Administrative Code (FAC) }\end{array}$ & $\begin{array}{l}\text { Additional plant permitting } \\
\text { under Title V; complete } \\
\text { recharacterization of all plant } \\
\text { operations presently identified } \\
\text { under the current operating } \\
\text { permit. }\end{array}$ & $\begin{array}{l}\text { Commenced Title V permitting } \\
\text { effort; will require } \\
\text { comprehensive evaluation of all } \\
\text { sources intended for operation } \\
\text { after close of DP mission and } \\
\text { initiation of new business, } \\
\text { commercialization, and potential } \\
\text { addition of another tenant. }\end{array}$ \\
\hline Enhanced Monitoring Rule & $\begin{array}{l}\text { Enhance record keeping and } \\
\text { emissions unit monitoring; some } \\
\text { elements are currently under } \\
\text { existing voluntary environmental } \\
\text { monitoring programs. }\end{array}$ & $\begin{array}{l}\text { Pinellas Plant specific } \\
\text { requirements will be dictated by } \\
\text { the FDEP/county and EPA } \\
\text { Federal requirements under } \\
\text { existing permit modifications and } \\
\text { a future Title V permit. }\end{array}$ \\
\hline $\begin{array}{l}\text { Accidental Release Rule/Risk } \\
\text { Management Plan }\end{array}$ & $\begin{array}{l}\text { Develop and formalize risk } \\
\text { management program at the } \\
\text { plant for specific compounds } \\
\text { exceeding thresholds upon } \\
\text { finalization of accidental release } \\
\text { rule. } \\
\text { Assess existing risks/model } \\
\text { impacts/develop training and } \\
\text { awareness plans. }\end{array}$ & $\begin{array}{l}\text { Will implement requirement } \\
\text { prior to regulatory compliance } \\
\text { date. }\end{array}$ \\
\hline $\begin{array}{l}\text { NESHAP for Radionuclides, } 40 \\
\text { Code of Federal Regulations } \\
\text { (CFR) Part 61, Subpart H or I }\end{array}$ & $\begin{array}{l}\text { Federally enforceable. The dose } \\
\text { standard is } 10 \text { mrem/year } \\
\text { effective dose equivalent; } \\
\text { Radionuclide Air Emissions } \\
\text { Annual Report; if dose } \geq 0.10 \\
\text { mrem/year, continuous } \\
\text { monitoring requirements apply. } \\
\text { (Present annual doses are less } \\
\text { than } 1 \% \text { of the } 10 \text { mrem } \\
\text { standard, and routine monitoring } \\
\text { is voluntarily conducted at the } \\
\text { Pinellas Plant site.) }\end{array}$ & $\begin{array}{l}\text { Characterization of existing } \\
\text { radiological emissions sources is } \\
\text { reported annually. } \\
\text { Title V permit application will } \\
\text { include radiological emission } \\
\text { sources. } \\
\text { Future increases in production } \\
\text { may cause dose in excess of } 1 \% \\
\text { of regulatory standard and } \\
\text { mandate continuous emissions } \\
\text { monitoring. }\end{array}$ \\
\hline $\begin{array}{l}40 \text { CFR-Part 82; Protection of } \\
\text { Stratospheric Ozone - Section } \\
608\end{array}$ & $\begin{array}{l}\text { Numerous provisions, including } \\
\text { prohibitions against knowingly } \\
\text { venting Class I or II substances, } \\
\text { with the exception of de minimis } \\
\text { losses and losses from normal } \\
\text { operational leaks, leak rate } \\
\text { standards for refrigerant systems, } \\
\text { and certification of service } \\
\text { technicians. }\end{array}$ & $\begin{array}{l}\text { Developed Pinellas Plant } \\
\text { Refrigerant Management Plan. } \\
\text { Developed data base to track } \\
\text { refrigerant systems and } \\
\text { determine equipment leak rates. } \\
\text { Identified rule applicability in } \\
\text { Title V air permit application. }\end{array}$ \\
\hline
\end{tabular}




\begin{tabular}{|l|l|l|}
\hline $\begin{array}{l}\text { NESHAP for Solvent Cleaning; } \\
40 \mathrm{CFR} 63\end{array}$ & $\begin{array}{l}\text { Summary of Requirements } \\
\text { for halogenated solvent cleaning } \\
\text { operations at the plant. }\end{array}$ & $\begin{array}{l}\text { Pinellas Plant Completed and } \\
\text { Planned Actions } \\
\text { evaluating the need for existing } \\
\text { halogenated solvent cleaners. No } \\
\text { additional halogenated solvent } \\
\text { cleaners will be procured. Plant } \\
\text { will increase use of aqueous } \\
\text { cleaning systems. }\end{array}$ \\
\hline
\end{tabular}

Since numerous forthcoming rules are under development which may apply to the Pinellas Plant, the complete impacts of all CAA amendments are not yet fully characterized. Due to the highly transitional state of the plant since the cessation of the DP mission, such as the alternate use initiative and the sale of the facility to the Pinellas County Industry Council (PCIC), it is not possible to fully identify all impacts at this time. Future third-party initiatives to commercialize the facility may invoke additional redressing of the existing air emissions permit and may necessitate individual emissions permits.

\section{Title V Permitting Activities}

During October 1994, the plant began the formal preparation to submit a Title $\mathrm{V}$ air permit application. The regulatory deadline to submit this application is November 15, 1995. The effort is a significant task and requires complete recharacterization of the Pinellas Plant sources, both significant and insignificant emissions units. The plant will complete this effort, which is currently underway, by the November 15, 1995 deadline. In the interim, the plant will continue to operate within limits of the existing Air Operating Permit, A052-233355. The Pinellas Plant will continually update the Title $\mathrm{V}$ emissions permit application to a current status until the time of regulatory review. The regulatory review of the Title $V$ permit application will be reviewed by the FDEP and Region IV of the EPA.

\subsubsection{Clean Water Act (CWA)}

The Pinellas Plant discharges industrial wastewater and untreated sanitary sewage to the PCSS Publicly Owned Treatment Works (POTW) in accordance with the plant's Industrial Wastewater Discharge Permit, 153IE. Discharges during 1994 did not exceed the permit limits, Federal Metal Finishing Pretreatment Standards, or Pinellas County Ordinance 91-26 [Ref. 10, 11, 12]. 


\section{National Pollutant Discharge Elimination System (NPDES)}

The Pinellas Plant does not currently have an NPDES permit for stormwater discharge associated with industrial activities. A permit application was submitted by the Pinellas Plant to EPA in September 1992, identifying two stormwater outfalls. An additional stormwater outfall was discovered and a revised stormwater discharge permit application was submitted to the EPA in April 1994, addressing the additional outfall. To date, the plant has not received a stormwater discharge permit from the EPA, but will comply with the requirements once it is received. The plant however takes all precautionary measures to prevent pollutants entering stormwater runoff.

\subsubsection{Safe Drinking Water Act (SDWA)}

The Pinellas Plant is in compliance with drinking water quality standards. Potable water is purchased from the Pinellas County Water System (PCWS). The plant does not perform any potable water treatment activities.

\subsubsection{Resource Conservation and Recovery Act (RCRA)}

The Pinellas Plant's Hazardous Waste operations are in compliance with the 40 CFR, Parts $260-264,266,268$, and 270, Chapter 62-730 of the FAC, and the Hazardous Waste Facility Permit, HO52-228925; the effective date was December 8, 1994.

The Pinellas Plant stores and/or treats hazardous wastes, but no hazardous wastes are disposed of on the plant site (i.e., landfills, lagoons, etc.). During 1994, 734 containers and five 20-cubic yard rolloffs of RCRA hazardous and nonhazardous wastes were shipped from the Pinellas Plant for disposal. All hazardous waste is shipped off the plant site for disposal at a RCRA-approved disposal site. Hazardous waste storage at the Pinellas Plant falls under two categories, 90-day hazardous waste storage not requiring a permit, or permitted storage not to exceed one year. Permitted storage location and waste types for hazardous waste are identified in the Hazardous Waste Facility Permit. Treatment operations include thermal treatment of small charge explosives and chemical treatment of water reactive compounds, such as calcium metal, calcium bimetals, and solid wastes contaminated with lithium metal. The Pinellas Plant conducts all treatment operations in accordance with methodologies detailed or referenced in the plant's Hazardous Waste Facility Permit. 
The FDEP and/or the EPA inspect the plant's hazardous waste operations at least annually to assure compliance with governing regulations. On November 9, 1993, the FDEP performed an unannounced inspection and identified two violations. One of these violation was dismissed after the plant submitted additional information to the FDEP. The other violation was resolved when the plant submitted a contingent post-close plan for a hazardous waste storage tank. In April 1994, the FDEP and the Pinellas Plant signed a short form consent order settlement. This consent order stated that "the corrective actions required to bring the facility into compliance have been performed. On February 7, 1994, the annual RCRA audit was performed. The FDEP has not yet issued a final report.

There are no Underground Storage Tanks (UST) at the Pinellas Plant. The last UST was removed from the plant in September 1991, in accordance with state regulations as administered by the Pinellas County Public Health Unit.

\section{Hazardous and Solid Waste Amendments (HSWA)}

The plant's HSWA Permit issued by EPA Region IV requires the permittee to investigate any releases or potential releases of hazardous waste or hazardous constituents from any Solid Waste Management Unit (SWMU) at the plant regardless of the time the waste was placed in the unit. It also requires appropriate corrective actions for any releases.

The Pinellas Plant completed an investigation of 15 SWMUs in accordance with the HSWA portion of the plant's RCRA Part B Permit, issued February 9, 1990. The plant received final approval of the RCRA Facility Investigation (RFI) Report from the EPA in February 1993. This report recommended corrective measures for only four SWMUs. Corrective Measure Studies (CMSs) were completed for three of these SWMUs. During January and February 1993, the Pinellas Plant conducted an Interim Corrective Measure (ICM) at the Former Pistol Range SWMU. As part of this action, the plant submitted an interim measure report to EPA in April 1993. This interim measure also served as the final corrective measure and eliminated the need for a CMS.

In 1992, a new SWMU was discovered, the West Fenceline area. This site was assessed in 1993, and the RCRA Facility Assessment (RFA) and the RFI requirements were satisfied. An Interim Measures Plan was submitted for the West Fenceline Area in March 1994. This interim measure proposed a technology for cleanup that is both innovative and is expected 
to have application at other Pinellas Plant SWMUs. The plant received approval of this measure in November 1994.

The Pinellas Plant conducted an RFA in 1993 at the Wastewater Neutralization/Building 200 Area. The RFA Report included a recommendation to the EPA that this area be added as a SWMU to the facility's HSWA permit and that an RFI be performed. The EPA approved this RFA in April 1994, and the plant submitted an RFI Plan in November 1994.

\subsubsection{Comprehensive Environmental Response, Compensation, and}

\section{Liability Act (CERCLA)}

Under CERCLA Section 120, each department, agency, and instrumentality of the United States is subject to, and must comply with, CERCLA as any nongovernmental entity. This includes reporting spills and environmental releases to the EPA that exceed the regulatory quantity threshold. There were no Reportable Quantity (RQ) releases at the Pinellas Plant during 1994.

The plant is currently involved as a Potentially Responsible Party (PRP) in the assessment of one CERCLA site, Peak Oil. Peak Oil was a used oil reclamation facility and has been placed on the National Priorities List by EPA. EPA identified the Pinellas Plant as one of many PRPs. The plant participates in cleanup through the PRP steering committee. The EPA provided a de minimis settlement offer to the plant on December 28, 1994.

\subsubsection{National Environmental Policy Act (NEPA)}

The National Environmental Policy Act of 1969, as amended, requires "all agencies of the Federal Government" to prepare a detailed statement on the environmental effects of proposed "major Federal actions significantly affecting the quality of the human environment." The Pinellas Plant administers an in-house NEPA program to assess planned changes in plant facilities and operations.

Significant 1994 NEPA activities included one Environmental Assessment (EA), the Commercialization of the Pinellas Plant. The Commercialization EA describes conditions that would occur as the result of leasing the plant to commercial entities for the purpose of conducting commercial manufacturing and research activities. On August 15,1994, the Assistant Secretary of Energy for Environment, Safety and Health issued a Finding of No Significant Impact (FONSI). 


\subsubsection{Toxic Substances Control Act (TSCA)}

Materials regulated under TSCA include Polychlorinated Biphenyls (PCB) and asbestos. The Pinellas Plant has no known PCBs on site. The last $\mathrm{PCBs}$ and $\mathrm{PCB}$-contaminated equipment were removed from the site in 1988.

The plant complies with all Occupational Safety and Health Administration (OSHA), EPA, state, and local regulations regarding the management and control of asbestos materials within the facility. Specialty Components developed and implemented an Operations and Maintenance (O\&M) Plan that meets the regulatory requirements of EPA's Asbestos Hazard Emergency Response Action (AHERA). All asbestos abatement projects are coordinated to ensure proper project notification to the state and local agencies, as required by EPA through 40 CFR Part 51, National Emission Standard for Asbestos.

The Pinellas Plant is in compliance with other sections of TSCA as they pertain to the plant's defense mission and safe shutdown activities.

\subsubsection{Federal Insecticide, Fungicide and Rodenticide Act (FIFRA)}

The Pinellas Plant uses pesticides in accordance with applicable regulations. If required, "Restricted Use" pesticides are only applied by contractors licensed by the State of Florida.

\subsubsection{Endangered Species Act (ESA)}

In response to a letter written by the United States Department of Interior, dated July 1991, listing potential endangered species, a subcontractor performed a site survey and found no listed endangered species, as defined in the ESA, at or near the plant. There was no action involving the ESA during 1994.

\subsubsection{National Historic Preservation Act (NHPA)}

Pinellas County has sites of historic and archaeological significance. None of these sites are on or in close proximity to the plant. In a letter, dated September 1991, the Florida Department of State, Division of Historic Resources, agreed that a survey of the site is unnecessary because it is unlikely that plant operations could impact sites listed or proposed for listing in the National Register. 


\subsubsection{Executive Order 11988, "Floodplain Management"}

The Pinellas Plant site is not located in the 100-year flood plain of Pinellas County. The plant is not associated with adverse impacts to the floodplain, as defined in the Floodplain Protection Executive Order.

\subsubsection{Executive Order 11990, "Protection of Wetlands"}

The U. S. Department of the Interior Fish and Wildlife Service identified the East and West Ponds as designated wetlands on the National Wetlands Inventory. The Pinellas Plant will conduct its activities to ensure that destruction, loss, or degradation of these wetlands is minimized, as required by the Wetlands Protection Executive Order.

\subsubsection{Emergency Planning and Community Right to Know Action of 1986 (EPCRA)}

The Pinellas Plant annually reports the toxic chemical inventory quantities and release quantities required by EPCRA. This act, also known as Title III of the Superfund Amendments and Reauthorization Act (SARA) of 1986, requires, under Section 312, the disclosure of toxic chemical inventory data by March 1 of each year. SARA also requires, under Section 313, toxic chemical release reporting by July 1 of each year. The plant is in compliance with the reporting requirements of EPCRA. Six of the 16 materials reported under Section 312 are extremely hazardous substances. They are ammonia, hydrofluoric acid, nitric acid, phosphorus, sulfuric acid, and toluene 2,4 diisocyanate. Material Safety Data Sheets (MSDS) for all reportable materials under Section 312 of SARA were submitted to the local emergency planning committee, state emergency response commission, and the local fire department in accordance with Section 311.

\subsection{Other Major Environmental Issues and Actions}

\section{Waste Management}

The Pinellas Plant's Hazardous Waste Facility Permit was renewed by the FDEP in 1994. The effective date of the permit was December 8, 1994. The permit will expire August 15,1998. All sections of the permit application were approved by the FDEP, except those dealing with Subpart X, Miscellaneous Treatment Units. These sections are still being evaluated by the FDEP.

DOE 5820.2 regulates Low Level Waste (LLW). The Pinellas Plant's LLW consists of small quantities of classified weapons components and compactable 
solid wastes, such as lab coats, finger cots, shoe covers, tools, and construction debris. These wastes are contaminated with tritium. LLWs are stored on the plant site prior to shipment for disposal. The Pinellas Plant uses approved 17C 55gallon drums and B-25-90-4 steel boxes to ship LLW. These wastes are disposed of at DOE's Savannah River Site. With the advent of the DOE reconfiguration process, the Pinellas Plant will handle and ship an increased amount of radioactive waste over the next two years.

A significant issue still facing the plant is the possibility of generating and then disposing of mixed (hazardous and radioactive) wastes. Regulations regarding the handling and disposal of these wastes are stringent and a few Mixed Waste (MW) disposal sites are in operation. The DOE signed an agency-wide disposal agreement with Envirocare of Utah (a commercial facility), which requires the generating site to obtain an exemption request from DOE 5820.2. None of the DOE MW sites are available to the Pinellas Plant at this time. These sites include the storage only at Hanford, the Nevada Test Site, which has not yet received approval from the state of Nevada, and the planned Savannah River Site incinerator, which is not yet open. The plant is therefore preparing an exemption request to DOE 5820.2, for submittal during the first quarter of 1995 , for a potential low-level MW stream. This exemption will permit the plant to dispose at Envirocare.

The Pinellas Plant is seeking approval from the Nevada Test Site for shipment of LLW, including solidified oil and laboratory trash. The plant is revising the initial application to incorporate comments from DOE Nevada. The Nevada Test Site audit team is scheduled to visit the plant in April 1995, and upon Nevada Test Site approval, initial shipments are planned by September 1995. Also, the Pinellas Plant moratorium document, which describes procedures to minimize the quantities and types of chemicals permitted in tritium process areas, was approved in principle. The requirements in the moratorium document, the Savannah River Site waste acceptance criteria, the Nevada Test Site waste acceptance criteria, and other internal documents minimize the potential to generate $M W$ at the Pinellas Plant.

\section{Environmental Restoration and Permitting}

Accelerated cleanup actions of the solvent-contaminated groundwater at the 4.5 Acre Site and the Northeast Site continued through 1994. The remediation technique employed, pump and treat, draws the industrial solvent contaminants back onto the site and reduces the overall concentration of these contaminants in the groundwater through a series of strategically located recovery wells. The groundwater is treated by metals precipitation (for removal of naturally occurring iron) and air stripping of VOC contaminants prior to discharge. The discharge from the groundwater treatment system is routed to the plant's Industrial 
Wastewater Neutralization Facility (IWNF) where it is neutralized, monitored, and discharged to the PCSS. The 4.5 Acre Site is a voluntary cleanup action. The Northeast Site cleanup is regulated by the plant HSWA permit.

Pursuant to EPA approval, the plant began implementing recovery well reconfiguration at the Northeast Site as part of an ICM. The well reconfiguration optimizes recovery of common industrial solvent contaminants from shallow and deep zones of the Surficial Aquifer. This system became operational in March 1994.

The DOE Innovative Treatment Remediation Demonstration (ITRD) project selected the Pinellas Plant Northeast Site for its first field demonstration. The mission of this program is to identify appropriate innovative cleanup technologies and collect cost and performance data on these technologies so that they will be more widely accepted within the regulatory and commercial arenas. In 1993, technologies were reviewed, and the following three were chosen for further evaluations for potential use at the Northeast Site: (1) enhanced bioremediation, (2) reductive dehalogenation, and (3) dynamic steam stripping. The plant performed further evaluations of these technologies in 1994 via parametric models, treatability studies, and field pilot studies. Based on study results, one or more of these technologies may be selected and implemented at the Northeast Site.

On August 11, 1994, the PCSS performed a site inspection that included the production plating area, the photographic silver recovery units, the IWNF, and the nonhazardous waste treatment process. No violations or noncompliances were identified during the inspection.

On September 13, 1994, the PCAQD inspected the Pinellas Plant for compliance to the Air Operating Permit. The PCAQD toured the plant, inspected active sources and scrubbers, and reviewed chemical usage and emission logs. The PCAQD documented in their report that the plant is in compliance with all conditions of the permit.

On November 3, 1994, the Florida Department of Health and Rehabilitative Services (HRS) Office of Radiation Control performed an annual inspection of the plant for compliance with their regulations on radiological air and wastewater effluents. No violations were noted.

On November 14, 1994, the Pinellas County Public Health Unit of Health and Rehabilitative Services conducted a petroleum storage tank inspection. There were no noncompliances noted during the inspection. 


\subsubsection{Tiger Team Assessment of the Pinellas Plant, January 1990}

Sixty-one environmental findings were identified during the environmental assessment portion of the Tiger Team Assessment of the Pinellas Plant in January 1990. Of these 61 findings, 14 concerned air emissions, 1 pertained to soil sampling, 12 were solid waste issues, 5 were groundwater findings, 4 concerned waste management, 4 pertained to TSCA, 3 were Quality Assurance (QA) issues, 3 were radiological emissions findings, 6 concerned industrial wastewater, 6 pertained to NEPA, and 3 were environmental monitoring issues. As stated in the DOE's assessment document [Ref. 13], the problems identified do not present an imminent risk to the public or the environment from continued operation of the plant. The efforts to resolve and close Tiger Team findings are identified in detail in the Pinellas Plant Final Action Plan, Supplement 1 [Ref. 14]. Of the 61 original environmental findings, 59 are certified complete by DOE. The remaining two are in revision.

\subsection{Summary of Permits}

\subsubsection{RCRA Permit}

The Pinellas Plant currently possesses a dual RCRA Part B Permit, with the FDEP administering the hazardous waste treatment and storage requirements and the EPA administering the assessment and remediation of SWMUs. A dual permit was issued because the FDEP does not have EPA authorization to administer the HSWA provisions of RCRA.

Permitted storage for hazardous waste is identified in the Hazardous Waste Facility Permit. Treatment operations include thermal treatment of small charge explosives and chemical treatment of water reactive compounds, such as calcium metal, calcium bimetals, and solid wastes contaminated with lithium metal. The Pinellas Plant conducts all treatment operations in accordance with methodologies detailed or referenced in the plant's Hazardous Waste Facility Permit.

The plant's HSWA Permit, FL6 890090 008, issued by EPA Region IV on February 9,1990 , requires the permittee to investigate any releases or potential releases of hazardous waste or hazardous constituents from any SWMU at the plant regardless of the time the waste was placed in the unit. The permit also requires appropriate corrective actions for any releases. This permit requires the permittee to certify annually that hazardous waste generation is minimized to the extent practicable. 


\subsubsection{Industrial Wastewater Discharge Permit}

The Pinellas Plant discharges $\mathrm{pH}$-neutralized industrial wastewater and untreated sanitary sewage to the PCSS. The Pinellas County Industrial Wastewater Discharge Permit, 153-IE, was renewed on August 28, 1994 and expires August 28, 1997.

\subsubsection{Stormwater Discharge Permit}

An individual Stormwater Discharge Permit application for two outfalls was submitted in September 1992. A third, previously unknown, outfall was sampled during two representative storm events in 1993. The plant sent a revised permit application to EPA in April 1994. The plant has not yet received a stormwater discharge permit, or comments from EPA on the permit application.

\subsubsection{Air Emissions Permit}

On February 4, 1994, the FDEP issued the plant an Air Operating Permit, A052-233355. The permit defines limits for atmospheric chemical emissions from the plant. This permit limits annual plant emissions of VOCs, OCs, particulates, sulfur dioxide, nitrogen oxides, carbon monoxide, and hydrocarbons to $19.52,21.58,0.6,0.7,0.5,0.1$, and 0.025 tons, respectively. The permit expires January 25, 1999. 
This page left blank intentionally. 
The Environmental Monitoring Program maintained by the Pinellas Plant is designed to meet the following objectives:

- Determine the effectiveness of treatment and control mechanisms for environmental releases.

- Provide measurements of discharge concentrations for comparison with applicable standards.

- Assess the concentrations of these discharges in the environment.

The environmental effects of plant radiological and nonradiological effluents are minimal, and the facility has implemented a proactive program to ensure compliance with the provisions of all new environmental laws and DOE regulations.

\subsection{Environmental Monitoring Summary}

\subsubsection{Nonradiological Monitoring}

Air

The Pinellas Plant received an Air Operating Permit, AO52-233355 [Ref. 15]. This permit defines the requirements for limiting the quantities of various VOCs and OCs that the plant may release to the environment through air emissions. Actual VOC/OC emissions for 1994 are reported in Section 5.

The permanent on-site meteorological monitoring station was in service during 1994 and provided excellent data throughout the year. Examples are provided in Tables 1-1 and 1-2.

\section{Water}

The Pinellas Plant discharges liquid effluents consisting of sanitary sewage and $\mathrm{pH}$-neutralized industrial process wastewaters to the PCSS. This discharge is regulated under Pinellas County Ordinance No. 91-26 [Ref. 18] and the DOE Pinellas Plant Industrial Wastewater Discharge Permit 153-IE [Ref. 11]. The Pinellas Plant is subject to the effluent limitation guidelines of the Metal Finishing Point Source Category identified in 40 CFR Part 433 developed by the EPA. Where both county standards and national standards apply to a pollutant, the plant complies with the more stringent of the two criteria. As specified in the Pinellas 
Plant Environmental Monitoring Plan [Ref. 1], the industrial, sanitary, and combined waste streams are sampled to verify permit compliance using the following schedule:

- $\mathrm{pH}$ - continuously monitored

- metals - sampled weekly

- cyanide, Total Suspended Solids (TSS) and Biochemical Oxygen Demand (BOD) - sampled monthly

- Total Toxic Organics (TTO) - sampled semiannually

- Oil/Grease - sampled monthly

Sample collection and analysis is in accordance with approved methodologies as specified in the Industrial Wastewater Discharge Permit. The plant forwards monthly reports of the monitoring data to the PCSS Industrial Program Manager. Additionally, Pinellas County maintains a sampling station on Pinellas Plant property for periodic, independent verification of compliance

A summary of the average 1994 wastewater discharge concentrations for regulated parameters is shown in Table 5-3 of Section 5. Most parameters are routinely Below Detection Limit (BDL). There were no instances in which the permitted levels were exceeded in 1994. 


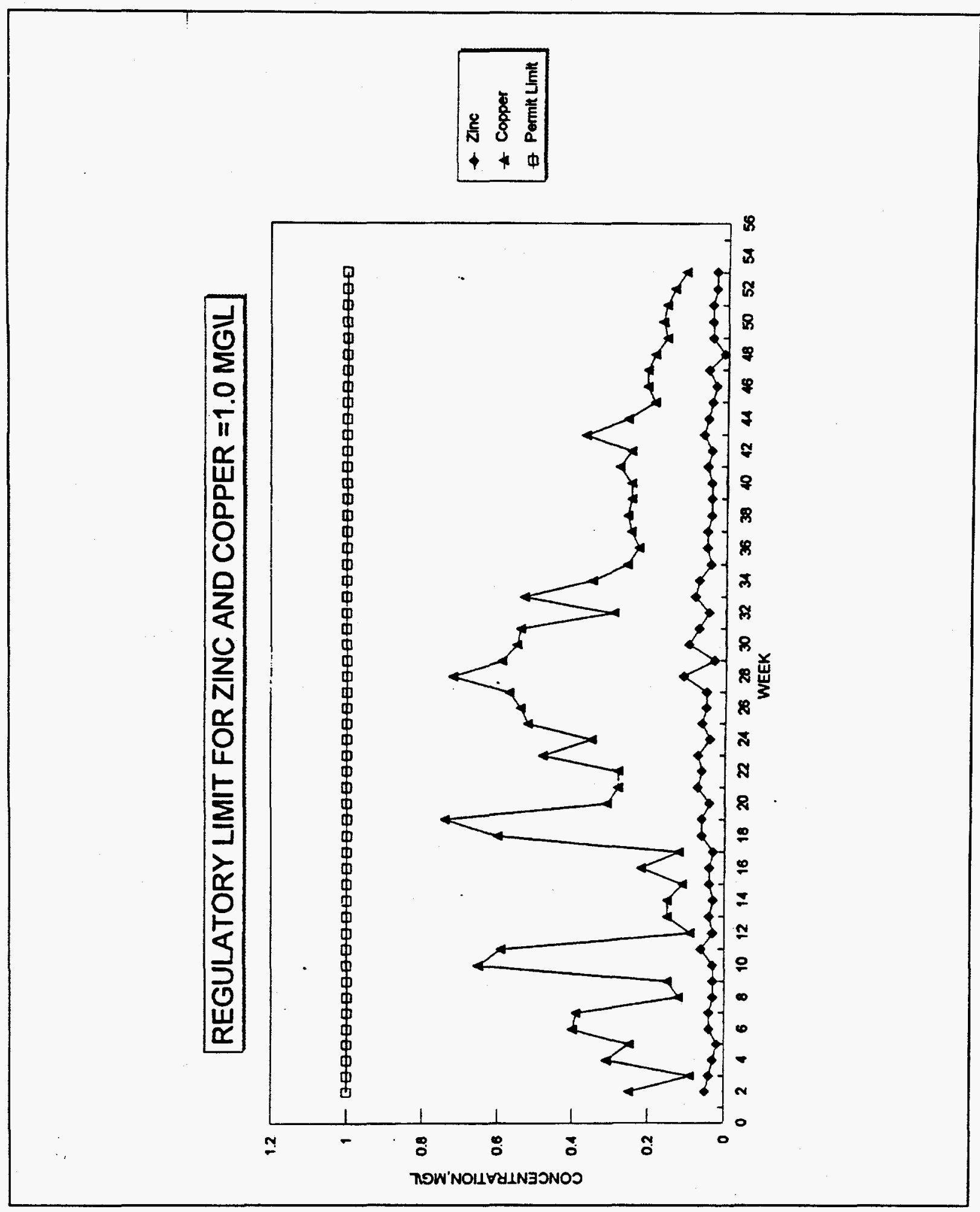

Figure 3-1. Regulated Liquid Effluent Releases Above Detection Limit, 1994 


\subsubsection{Radiological Monitoring}

Air

Small quantities of radioactive tritium and $\mathrm{Kr}-85$ are discharged into the air from plant operations. Four point sources of radiological air emissions are the Building 100 main stack, the Building 100 laboratory stack, the Building 200 stack, and the Building 800 stack. Two roof openings emit very small amounts of tritium. As specified in the Pinellas Plant Environmental Monitoring Plan, these sources are monitored and sampled continuously for tritium to verify compliance with 40 CFR Part 61, Subpart H [Ref. 8] and DOE 5400.5, Radiation Protection of the Public and the Environment [Ref. 3]. $\mathrm{Kr}-85$ emissions are monitored continuously and are quantified using mass balance calculations. In addition to the stack samplers, there is a network of eleven on-site and six off-site air sampling stations that continuously sample the ambient air for tritium. There are no area sources of radiological emissions at the Pinellas Plant.

Because the plant used a sealed plutonium heat source in the RTG product that was discontinued more than three years ago, the plant continues to sample the ambient air for plutonium. No plutonium was ever released inside the building or to the outside environment, and no plutonium has been measured in air.

Table 3-1. Summary of Air Environmental Monitoring at the Pinellas Plant in 1994

\begin{tabular}{|c|c|c|c|c|}
\hline Location & $\begin{array}{l}\text { Number of } \\
\text { Stations }\end{array}$ & $\begin{array}{l}\text { Sample } \\
\text { Collection } \\
\text { Frequency }\end{array}$ & $\begin{array}{l}\text { Analysis } \\
\text { Frequency }\end{array}$ & Nuclides \\
\hline $\begin{array}{c}\text { Radiological Exhaust } \\
\text { Stacks }\end{array}$ & $\begin{array}{l}2 \\
4\end{array}$ & $\begin{array}{l}\text { Continuous } \\
\text { Continuous }\end{array}$ & $\begin{array}{c}\text { Daily } \\
\text { Monthly }\end{array}$ & $\begin{array}{l}\text { Tritium } \\
\text { Tritium }\end{array}$ \\
\hline $\begin{array}{c}\text { On-Site Sampling } \\
\text { Stations }\end{array}$ & $\begin{array}{c}11 \\
4\end{array}$ & $\begin{array}{l}\text { Continuous } \\
\text { Continuous }\end{array}$ & $\begin{array}{l}\text { Monthly } \\
\text { Quarterly }\end{array}$ & $\begin{array}{c}\text { Tritium } \\
\text { Plutonium }\end{array}$ \\
\hline $\begin{array}{l}\text { Off-Site Sampling } \\
\text { Stations }\end{array}$ & $\begin{array}{l}6 \\
5\end{array}$ & $\begin{array}{l}\text { Continuous } \\
\text { Continuous }\end{array}$ & $\begin{array}{l}\text { Monthly } \\
\text { Quarterly }\end{array}$ & $\begin{array}{c}\text { Tritium } \\
\text { Plutonium }\end{array}$ \\
\hline
\end{tabular}

A summary of the results of the stack sampling for 1994 is shown in Table 3-2. The results show that radiological emissions at the Pinellas Plant have remained at very low levels since 1991. Results of the on- and off-site sampling stations are presented in Section 4. 
Table 3-2. Summary of Total Radiological Stack Emissions (Tritium and $\mathrm{Kr}-85$ ) for 1994

\begin{tabular}{|l|c|}
\hline Source & Annual Emissions (curies) \\
\hline Building 100 Main Stack & 35.69 \\
\hline Building 100 Laboratory Stack & 2.08 \\
\hline Roof Opening 378 & 0.0015 \\
\hline Roof Opening 413 & 0.0002 \\
\hline Building 200 Stack & BDL \\
\hline Building 800 Stack & 0.081 \\
\hline Total for 1994 & 37.85 \\
\hline Total for 1993 & 30.36 \\
\hline Total for 1992 & 49.7 \\
\hline Total for 1991 & 115 \\
\hline
\end{tabular}

\section{Waste Water}

Small quantities of radioactive tritium are present in the plant's sanitary sewage and industrial waste streams. Just prior to leaving the IWNF, the sanitary sewage and industrial waste streams are combined and discharged to the PCSS. As specified in the Pinellas Plant Environmental Monitoring Plan [Ref. 1], a 24-hour composite sample is collected each day of the year from the sanitary, industrial, and combined waste streams and analyzed for tritium. Table 3-3 presents a summary of the total amount of tritium discharged in the liquid effluent in 1994.

Table 3-3. Tritium Discharged to PCSS, 1994

\begin{tabular}{|c|c|c|}
\hline Parameter & $\begin{array}{c}\text { HRS Discharge } \\
\text { Standard* }\end{array}$ & $\begin{array}{c}\text { Actual Discharge } \\
1994\end{array}$ \\
\hline $\begin{array}{c}\text { Average Monthly } \\
\text { Concentration, pCi/ml }\end{array}$ & 10,000 & 1.00 \\
\hline $\begin{array}{c}\text { Total Annual Quantity } \\
\text { Released, curies }\end{array}$ & 5 & .277 \\
\hline *FAC 10D-91.418, Control of Radiation Hazards \\
\hline
\end{tabular}

\section{Surface Water}

ES\&H routinely samples on-site and off-site stormwater retention/detention ponds. There are three on-site and 26 off-site locations that are sampled and analyzed for tritium. The results from 1994 are presented in Section 4. 
All plutonium, with the exception of calorimeter sources and small instrumentation calibration check sources, was removed from the plant in February 1991. In accordance with an agreement with the HRS and as specified in the Pinellas Plant Environmental Monitoring Plan [Ref. 1], the plant continues to collect and analyze soil samples for plutonium annually from two on-site and four off-site locations. The results are presented in more detail in Section 4. There was no plutonium from plant operations detected in soil samples collected in 1994.

\subsubsection{Groundwater Quality}

The Pinellas Plant monitors groundwater pursuant to requirements stated in DOE 5400.1, Chapter IV, [Ref. 2] and provides evaluations of implemented interim measures and surveillance of potential groundwater contamination sites. These sites include the 4.5 Acre Site and sites identified in the plant's HSWA Permit. Of the 205 monitoring, recovery, and test wells at the plant, approximately 150 are actively monitored either on a quarterly, biannual, or annual basis, dependent on the parameter of interest. Approximately one-half of the wells are sampled and analyzed for tritium quarterly.

Approximately 90 monitoring wells are sampled quarterly and analyzed for VOCs. Approximately 90 monitoring wells are sampled and analyzed for trace metals, respectively. Specialty Components Environmental, Safety and Health submits all raw data in a groundwater quarterly report to DOE/PAO. In addition, Specialty Components Environmental, Safety and Health summarizes monitoring data associated with sites undergoing interim measures and reports to DOE/PAO for transmittal to the FDEP and EPA.

During 1994, groundwater sampling at the plant site included field measurements for $\mathrm{pH}$, conductivity, and temperature. Some split samples were sent to an on-site analytical laboratory for volatile organic analyses confirmation. Table 3-4 presents a summary of all groundwater data collected during 1994. Data associated with field measurements is presented in Section 6, Groundwater Protection Program. Table 3-4 identifies each chemical constituent for which the maximum value detected exceeds its corresponding standard. The primary constituents of concern at the plant include solvent compounds and their decomposition products. Metals have also been detected above regulatory standards as part of the Environmental Restoration (ER) Program. The ER Program is discussed in more detail in Chapter 6. 
Table 3-4. Summary of Groundwater Monitoring Results, $\mu \mathrm{g} / \mathrm{l}$

\begin{tabular}{|c|c|c|}
\hline Parameter & Standard* & Maximum \\
\hline \multicolumn{3}{|l|}{ Trace Elements } \\
\hline Arsenic & 50 & 65 \\
\hline Cadmium & 5 & 9 \\
\hline Iron & 300 & 720,000 \\
\hline Lead & 15 & 140 \\
\hline Manganese & 50 & 2,600 \\
\hline \multicolumn{3}{|l|}{ Volatiles } \\
\hline trans-1,2-Dichloroethylene & 100 & 480,000 \\
\hline Benzene & 1 & 5,400 \\
\hline Dichloromethane & 5 & $2,000,000$ \\
\hline Toluene & 1,000 & 170,000 \\
\hline Trichloroethene & 3 & 725,000 \\
\hline Vinyl Chloride & 1 & 37,000 \\
\hline
\end{tabular}

\subsection{Compliance with the NEPA}

The Pinellas Plant routinely completes NEPA documentation for plant processes and project developments that require NEPA documentation and transmits them to DOE for review and final action. Lockheed Martin Corporate audits, DOE Technical Safety Appraisals and internal audits, and self-assessments ensure that the plant complies fully with NEPA.

The NEPA documentation process is initiated early in the project planning process through meetings with facility personnel to discuss the nature, cost, scope, and proposed timing of project implementation. The plant performs NEPA documentation status tracking using a computerized data base. The plant completes a standardized checklist describing the planned project, the project's potential impacts on the environment, and the applicable regulatory and permitting requirements. After internal review, the plant transmits the checklist to DOE and drafts additional DOE documentation, as needed, based on DOE determinations. 


\subsection{Significant Environmental Activities}

\subsubsection{Pollution Abatement}

\section{Nonhazardous Waste Treatment}

The Pinellas Plant received an Industrial Wastewater User's Permit on November 10, 1994 from the PCSS. This permit enables the Pinellas Plant to use a new nonhazardous treatment system to reduce the volume of nonhazardous waste that is shipped off site.

The Pinellas Plant also received permission on August 3, 1994, from the FDEP, to use two new closed-loop recycling units. The plant uses these units in the process development plating and equipment fabrication and test areas to clean and return rinsewater to the process.

\section{Health Physics Drain Replacement}

The Health Physics Drain System at the Pinellas Plant conveys wastewater from the tritium processing areas of the plant to the IWNF. This wastewater may therefore contain tritium. Underground sections of this drain system were replaced with above-ground piping with secondary containment. The underground sections will be flushed and filled with grout to prevent further use. This will prevent the potential for groundwater contamination from underground leaks and allows accessibility for inspections and repairs of above-ground piping.

\section{Biomedical Waste Program}

The Pinellas Plant developed, implemented, and maintains a comprehensive Biohazardous Waste Management Program. This program controls biomedical wastes generated by the plant's medical clinic, restrooms, and other specialized operations. The program ensures administrative and operational compliance with OSHA, U.S. Department of Transportation (DOT) and HRS rules, regulations, and policies. It includes written training programs, operating plans and procedures, and off-site treatment and disposal facility inspections. Waste Management implemented DOT regulations for container marking in February 1994. These regulations were not required until January 1995. Because of this proactive initiation, the program exceeds all regulatory requirements and employs best management practices. 


\section{Direct Discharge of Health Physics Tanks}

There are three 10,000 gallon Health Physics holding tanks at the IWNF. These tanks collect wastewater with low concentrations of tritium. After sampling and analysis of the tank contents for tritium and comparing the results to the plant As Low As Reasonably Achievable (ALARA) objective, the tanks are discharged through the IWNF to the PCSS along with the industrial wastewater and sanitary sewage. The sludge that collects in the bottom of the IWNF neutralization tank is a listed hazardous waste (F006, electroplating sludge). Since this sludge has the potential to contain minute concentrations of tritium, a project was initiated to direct the Health Physics wastewater discharge to the PCSS after neutralization. This redirection will mitigate the potential to generate mixed waste. Project construction began in 1994 and is expected to be completed and operational in 1995.

\subsubsection{Special Studies}

\section{Tritium Monitoring}

The plant implemented improvements in the sampling equipment and sampling procedures for ambient tritium sampling stations in 1994. These improvements resulted in better quantification of on- and off-site ambient tritium air concentrations. The plant added four new on-site tritium sampling stations in 1994, to significantly improve the quantification of the potential fenceline concentration of tritium.

\subsection{Assessments}

The Pinellas Plant must comply with Federal, State, and local regulations. External and internal oversight, as well as self-assessments helps ensure compliance.

Internal oversight is by the Environmental Oversight and Quality Assurance function of the Compliance/Ethics Programs Department. Any noncompliance findings require the development and implementation of a corrective action plan. In addition, Lockheed Martin Corporate Environmental Management provides oversight through routine site audits.

Self-assessments are conducted by employees within Environmental Restoration and Permitting and Waste Management. These self-assessments include assessments of Specialty Components and external contractor personnel performing sampling and maintenance activities. Corrective actions resulting from these self-assessments are used to improve the Environmental Monitoring Program and are documented and retained as quality assurance records. 
The Pinellas Plant's Environmental, Safety and Health Assessment Program is implemented plantwide to assure compliance with all laws and regulations. These Specialty Components Environmental, Safety and Health assessments focus on issues such as hazardous waste container identification, satellite accumulation, radioactive waste, scrap metal management, radioactive and nonradioactive air and wastewater effluents and NEPA. During 1994, assessments were performed by Specialty Components Environmental, Safety and Health on 59 operations and transition/shutdown areas. Where needed, corrective actions were implemented by the area owners and verified by Specialty Components Environmental, Safety and Health.

External oversight is provided by the DOE Pinellas Area Office, Albuquerque, and Headquarters personnel and by Federal, State, and local regulatory agencies. Any noncompliance findings require the development and implementation of a corrective action plan, quarterly status reports, and formal close-out procedures to ensure that the nonconforming item is corrected.

The Office of Environmental Audit (EH-24) conducted a Routine Environmental Audit of the Pinellas Plant from January 31 through February 11, 1994.

The objective of the audit was to advise the Secretary of Energy through the Assistant Secretary for Environment, Safety and Health of the adequacy of management systems to ensure compliance with Federal, State, local, and DOE environmental requirements and to evaluate application of proactive management practices. The scope of the audit was comprehensive and covered all areas of environmental management and included indepth reviews of air quality protection, surface water and drinking water quality, and waste management site programs.

The audit team identified numerous positive aspects of the plant's environmental programs, and only five findings were identified during the audit. The costs associated with the findings' ptanned actions were not significant. It is significant that there were no key findings against the Pinellas Plant as a result of this audit. All planned actions have been implemented.

\subsection{Pollution Prevention and Waste Minimization}

Pollution prevention and waste minimization requires a thorough understanding of the raw material inputs and waste products for all processes at the Pinellas Plant. To provide this information, a Pollution Prevention Opportunity Assessment (PPOA) team assesses processes that generate large amounts of hazardous waste. The PPOA team determines the areas that generate the largest waste streams and implements waste minimization and pollution prevention practices. PPOAs are an ongoing activity at the plant. During the first half of 1994, the primary activity of the PPOA team involved completing efforts to reduce the trichloroethylene waste stream from the Area 143 vapor degreaser. 
The team focused on reducing wastes generated during the thermal battery building process during the second half of the year. Other on-going pollution prevention and waste minimization programs include the following:

- Plantwide aluminum can recycling program (proceeds go to nonprofit environmental organizations)

- Sale of scrap metal and cardboard

- Off-site solvent reclamation

- Replacing chlorinated solvents with aqueous degreasers

- Solid sanitary waste managed by a commercial recycling firm

- On-site treatment of machine cutting fluid $(10,000$ gallons per year waste reduction)

- A plantwide office paper recycling program

- A laser printer cartridge recycling program

- Waste minimization/pollution prevention awareness training

- A packing material recycling program

Studies are also continuing to minimize or replace the halogenated solvents remaining in the manufacturing processes. In 1994, the Waste Minimization Pollution Prevention Opportunity Assessment (PPOA) Team conducted a study on the thermal battery product. This was an effort to replace the 1,1,1-Trichloroethane (TCA) cleaning solvent with Oakite to reduce the use of halogenated solvents and the waste created from its usage via the cleaning process. A recommendation to incorporate this into the process will be included in the formal, final write up of the PPOA Report. The problem presented in this application is that the product is actually cleaned in a dry room area; therefore, aqueous substances would create problems. The team has addressed this concern by recommending that the cleaning be performed outside of the dry room.

As safe shutdown and transition activities take place, new opportunities for recycling and reuse are incorporated into the Waste Minimization Program. For example, the materials reuse center in the General Stock area stores excess office supplies that are accumulated as various production areas are shutdown.

Departments save money by requesting reusable items instead of purchasing new ones from General Stock. 


\subsection{Reports and Certifications}

The Pinellas Plant's Environmental, Safety and Health organization is responsible for ensuring that all reports and certifications required by Federal or State regulations or DOE Orders are completed as required. The plant submitted the 1994 Waste Generation/Disposal Summary Report to the PCSS in January 1995. This report is required by the plant's Wastewater Discharge Permit. The plant also submitted monthly reports on the results of the Wastewater Monitoring Program to the PCSS in 1994. No permit limits were exceeded in 1994.

Shipments of hazardous waste originating from the plant must be accompanied by a uniform hazardous waste manifest. This manifest requires the generator of the waste to certify that packaging, marking, and labeling comply with DOT regulations for hazardous material transportation, and that the facility has a program in place to reduce the volume or toxicity of waste generated to the lowest practicable levels.

The FDEP also requires generators of waste to complete a generator's biennial report on the types and amounts of hazardous waste treated, stored, and disposed of. The biennial waste report to the EPA was submitted March 1, 1994.

\subsection{Training}

Training is a high priority activity at the Pinellas Plant. All Pinellas Plant employees must participate in a hazard communication program meeting OSHA requirements and tailored to the types of chemicals used by the employee. This annual program provides guidance and information, such as protective clothing, routes of exit, emergency spill procedures, fire prevention procedures, and waste disposal procedures. Approximately 800 employees have received training in waste minimization and pollution prevention awareness. Also, approximately 400 plant personnel who handle hazardous waste complete computer-based training in RCRA regulations, which ensures compliance awareness and defines specific employee responsibilities.

Representative members of Waste Management and Environmental Restoration and Permitting received extensive training in hazardous material transportation, hazardous material response, and protection of the environment.

Most hazardous materials response team members receive additional training beyond the 40-hour initial and 8-hour annual refresher training required by OSHA. These employees attend emergency response training with the local fire department and participate in on-site monthly exercises and drills. They also attend additional training to qualify for various team responsibilities, which include specialist, technician, and incident commander. 


\subsection{ENVIRONMENTAL RADIOLOGICAL PROGRAM INFORMATION}

The Radiological Monitoring Program includes sampling air and water for tritium and air, water, and soil for plutonium, both on site and in the environment surrounding the Pinellas Plant. Impacts to the public and the environment from plant operations are determined from a monitoring program information data base.

Tritium has a half-life (how long it takes for half the amount to be removed by radioactive decay) of 12.3 years. $\mathrm{Kr}-85$ has a half-life of 10.7 years. Tritium can exist in the gas, oxide, or vapor state. Tritium in the oxide state behaves like water chemically and is readily exchanged with water in the body. Because of this, tritium oxide is greater than 10,000 times more biologically reactive than tritium gas. However, since water is excreted readily by the body, tritium oxide has a biological half-life of 4 to 18 days (i.e., how long it takes for half of the tritium to be eliminated from the body). $\mathrm{Kr}-85$ exists only in the gaseous state. Plutonium-238 has a half-life of 90 years and Plutonium-239 has a half-life of 24,000 years.

\subsection{Radiation Dose Terminology and Dose Standards}

Absorbed Dose--The measure of dose or exposure to ionizing radiation to an organ of the body is the absorbed dose. It is defined as the quantity of radiation energy absorbed by an organ divided by its mass. The International System of Units (SI) unit of absorbed dose is the gray. A gray is equal to 1 joule per kilogram of organ mass. A gray is equal to $100 \mathrm{rad}$; therefore, $1 \mathrm{rad}$ is an amount of absorbed energy equivalent to one hundredth of a joule. Since the absorbed dose does not incorporate the biochemical effects of differing types of ionizing radiation, the absorbed dose is inadequate for predicting health effects associated with exposure to radiation.

Dose equivalent--The dose equivalent to an organ exposed to a source of ionizing radiation is the absorbed dose to the organ multiplied by a quality factor of 1 for gamma radiation and beta particles and 20 for alpha particles. The dose equivalent is expressed in units of rem or sievert.

Becquerel (Bq)--A unit of radioactivity defined as 1 disintegration per second. A curie (Ci) of activity is equal to $3.7 \times 10^{10} \mathrm{~Bq}$.

Sievert (Sv)--A unit of dose equal to $100 \mathrm{rem}$. One rem $=0.01$ sievert.

Dose Conversion Factor for Tritium Oxide--The 50-year committed effective dose equivalent is $2.56 \times 10^{-11} \mathrm{~Sv} / \mathrm{Bq}\left(9.5 \times 10^{-8} \mathrm{mrem} / \mathrm{pCi}\right)$ from inhalation and $1.7 \times 10^{-11} \mathrm{~Sv} / \mathrm{Bq}\left(6.3 \times 10^{-10} \mathrm{mrem} / \mathrm{pCi}\right)$ from ingestion.

Collective (Population) Dose--The term "collective (population) dose" refers to the sum of the individual doses received by all members of the population.

Committed Dose--An individual's "committed dose" refers to the total dose resulting from an intake that has accumulated over the individual's projected lifetime. In mathematical models, a 50-year time period is used to calculate committed dose. 
Derived Concentration Guide (DCG)--The concentration of radionuclide in air or water that under conditions of continuous exposure for one year by one exposure mode, such as ingestion of water, submersion in air, or inhalation, would result in an effective dose equivalent of 100 mrem $(1 \mathrm{mSv})$ [Ref. 3].

Effective Dose Equivalent (EDE)--The effective dose equivalent combines dose equivalents received by all organs of the body into a weighted average that is related to an individual's total risk of experiencing health effects. Weighting factors are determined for the health effects of radiation on each organ based on statistical averages for large populations.

These weighting factors are 0.25 for gonads, 0.15 for breast, 0.12 for red bone marrow, 0.12 for lung, 0.03 for thyroid, 0.03 for bone surfaces, and 0.30 for the remaining organs of the body. The effective dose equivalent combines individual organ doses into a single number which can be added to summarize the impacts of multiple radionuclides and radiation from internal and external sources.

Monitoring--The direct in-situ sensing of a media (air, water, soil) for constituent concentration.

Reference Man--A hypothetical aggregation of human physical and physiological characteristics arrived at by international consensus. A "reference man" is assumed to inhale 8400 cubic meters of air and ingest 730 liters of water per year.

Sampling--The collection of a representative portion of a media (air, water, soil) that is transported to another location to be analyzed for constituent concentration.

\subsection{Radioactive Efmuent Data}

\subsubsection{Air}

Small quantities of tritium and $\mathrm{Kr}-85$ are released to the air from operations at the plant through four radiological exhaust stacks, the Building 100 main and laboratory stacks, the Building 200 stack, and the Building 800 stack (Figure 4-1). Specialty Components Environmental, Safety and Health sampled the discharges from these stacks continuously for tritium during 1994. Discharges from two roof openings 378 and 413 were measured during a one-month period in July 1994. $\mathrm{Kr}-85$ is discharged only through the Building 100 main stack and is monitored by ionization chamber instrumentation. The results of the stack and roof opening effluent sampling are presented in Table 4-1. The monthly stack release data is plotted in Figure 4-2. 


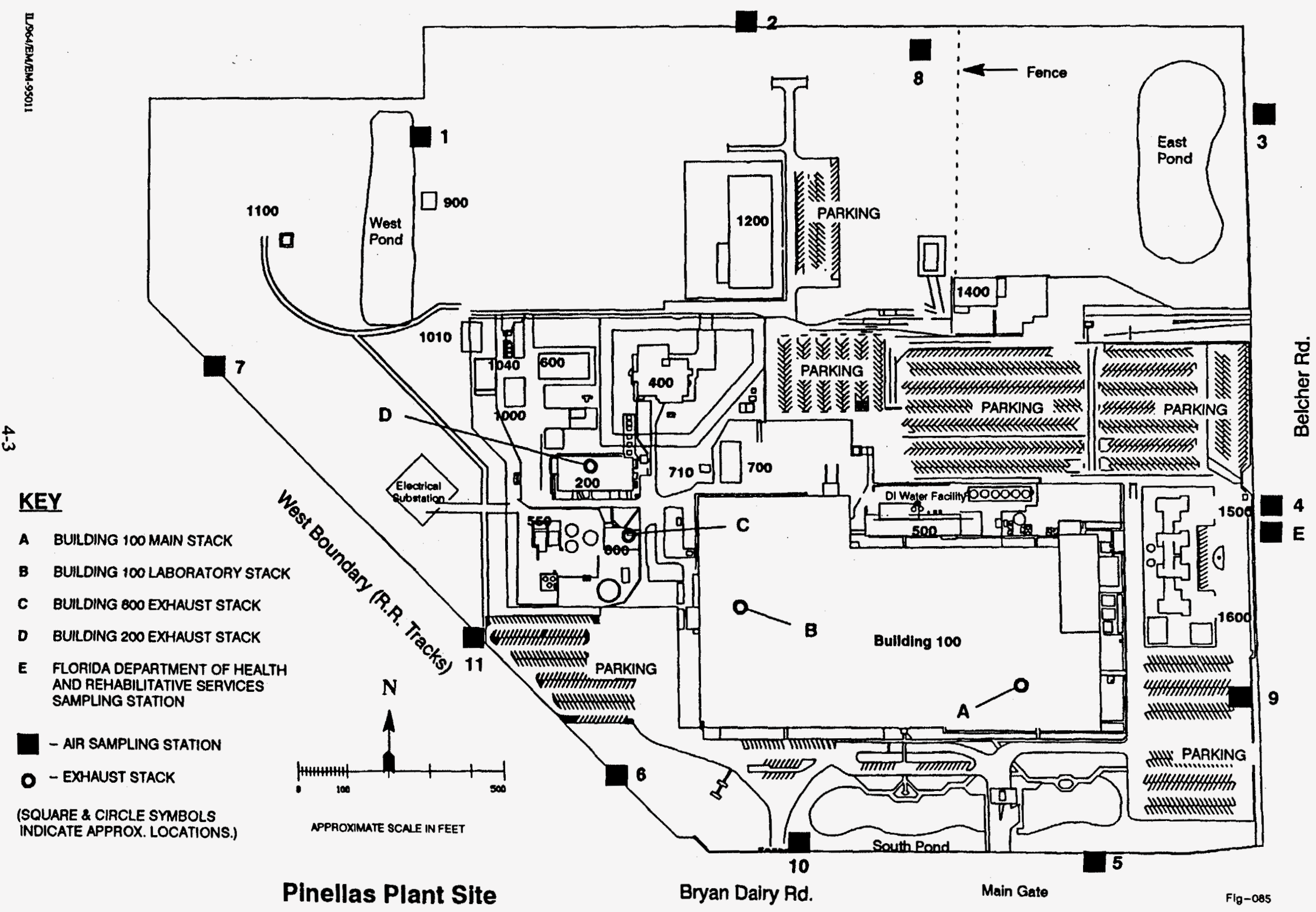

Figure 4-1. On-Site Exhaust Stack and Ambient Air Sampling Station Locations 
Table 4-1. 1994 Stack Releases to the Atmosphere

\begin{tabular}{|l|l|l|}
\hline Release Point & Radionuclide & \multicolumn{2}{|c|}{ Activity, Ci (Bq) } \\
\hline Bldg. 100 Main & Tritium gas \& oxide & $22.79\left(8.43 \times 10^{11}\right)$ \\
\hline Bldg. 100 Main & Krypton-85 & $12.90\left(4.77 \times 10^{11}\right)$ \\
\hline Bldg. 100 Lab & Tritium gas \& oxide & $2.08\left(7.70 \times 10^{10}\right)$ \\
\hline Roof Opening 378 & Tritium gas \& oxide & $.0015\left(5.51 \times 10^{7}\right)$ \\
\hline Roof Opening 413 & Tritium gas \& oxide & $.0002\left(7.80 \times 10^{6}\right)$ \\
\hline Bldg. 200 & Tritium gas \& oxide & Below detection limit* \\
\hline Bldg. 800 & Tritium gas \& oxide & $.081\left(3.0 \times 10^{9}\right)$ \\
\hline Total Emissions & & $37.85\left(1.4 \times 10^{12}\right)$ \\
\hline Detection Limit is approx. .006 curies from the Bldg. 200 stack. \\
\hline
\end{tabular}

\section{TRITIUM STACK EMISSIONS, 1994}

1994 ALARA limit $=120$ curles

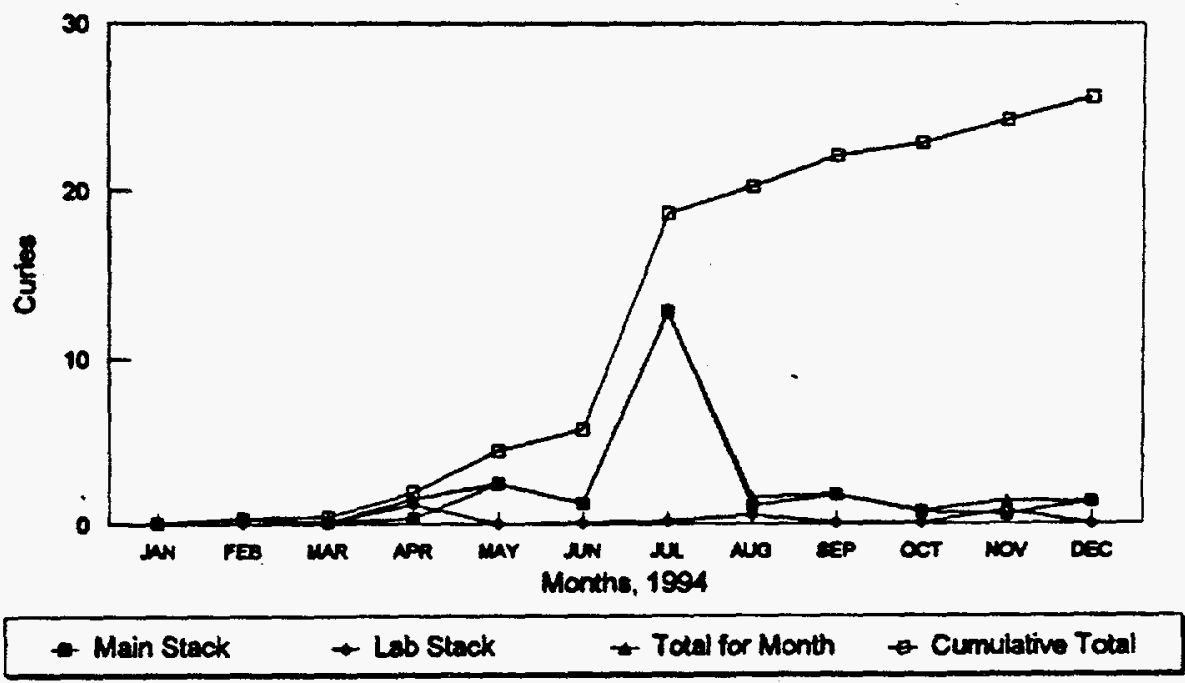

Figure 4-2. Tritium Stack Emissions, 1994 
The cumulative total of tritium stack emissions for 1994 is higher ( 24.96 curies) than that reported for 1993 (11.62 curies) and lower than that reported for 1992 (49.7 curies). This increase from 1993 is not statistically significant.

\subsubsection{Water}

Small quantities of tritium and very small quantities of naturally occurring uranium are present in the plant's wastewater discharge from the IWNF to the PCSS. The plant collects a 24-hour composite sample every day of the year from the sanitary, industrial, and combined waste streams at the IWNF (Figure 4-1) and analyzes the sample for tritium, as required by the Pinellas Plant Environmental Monitoring Plan [Ref. 1]. Table 4-2 presents a summary of the tritium discharges for each month of 1994. The data demonstrates that the average monthly and total annual discharges are well below the FAC regulatory discharge limits of $1.0 \times 10^{5} \mathrm{pCi} / \mathrm{ml}$ concentration and 5 curies total annual quantity released.

Table 4-2. Tritium Released in the Combined Waste Stream to the PCSS in 1994

\begin{tabular}{|l|c|c|}
\hline \multicolumn{1}{|c|}{ Month } & $\begin{array}{c}\text { Average Daily } \\
\text { Activity, pCi/ml }\end{array}$ & $\begin{array}{c}\text { Total Tritium } \\
\text { Discharged, } \\
\text { Curies }\end{array}$ \\
\hline January & .76 & 0.021 \\
\hline February & .96 & 0.024 \\
\hline March & .82 & 0.025 \\
\hline April & 1.64 & 0.037 \\
\hline May & 1.55 & 0.034 \\
\hline June & .60 & 0.035 \\
\hline July & 1.03 & 0.020 \\
\hline August & .62 & 0.010 \\
\hline September & 2.75 & 0.050 \\
\hline October & .45 & 0.008 \\
\hline November & .47 & 0.007 \\
\hline December & .40 & 0.006 \\
\hline Total 1994 & 1.00 & 0.277 \\
\hline
\end{tabular}

\subsection{Environmental Sampling for Radioactivity}

The Pinellas Plant has an extensive environmental sampling program in which samples of air, water, and soil are analyzed for the presence of radionuclides currently and previously used at the plant. 


\subsubsection{Air}

During routine operations, small quantities of tritium gas, tritium oxide, and $\mathrm{Kr}-85$ gas are discharged from radiological exhaust stacks. The plant has a network of sampling stations that use silica gel as the collection media to quantify the amount of tritium that is discharged. Primary sampling stations collect samples directly from the stacks, secondary sampling stations are located around the perimeter of the plant, and tertiary sampling stations are located throughout the county in a circular pattern around the plant (Figures 4-2 and 4-3). Sampling procedures and locations are detailed in the Environmental Monitoring Procedures Manual for Environmental Management [Ref 19].

\section{Ambient Air}

From January to August 1994, seven on-site stations continuously sampled the ambient air for tritium. In August 1994, four new stations were added on site, making a total of 11 on-site air sampling stations (Figure 4-1). Four on-site stations continue to sample for airborne plutonium even though the last plutonium heat sources were removed from the site in February 1991. There have never been any releases of plutonium at the Pinellas Plant.

Six off-site stations in Pinellas County continuously sample the ambient air for tritium (Figure 4-3). The Clearwater station was rendered inoperable as a result of a storm in March 1993. The Clearwater station was relocated to Clearwater Air Park. The Manatee County background station was relocated to the office of SWFWMD in Tampa. SWFWMD station's measurements represent the normal background level and are compared to the measurements at the other stations. The Pinellas County stations also sample for airborne plutonium. Plutonium isotopes $\mathrm{Pu}-238$ and $\mathrm{Pu}-239$ are analyzed because they were the isotopes in the RTG heat source. The results of the measurements of airborne radionuclides from Pinellas Plant operations are presented in Table 4-3.

The data shows that annual average concentrations of tritium in the ambient air ranged from below to slightly higher than detection limits, both at the plant boundary and in the local community, and below the DOE DCG limit of $1.0 \times 10^{-7} \mu \mathrm{Ci} / \mathrm{ml}\left(3.7 \times 10^{-3} \mathrm{~Bq} / \mathrm{ml}\right)$ for tritium in air [Ref. 3]. There were no airborne concentrations of plutonium above the minimum detection limit. 


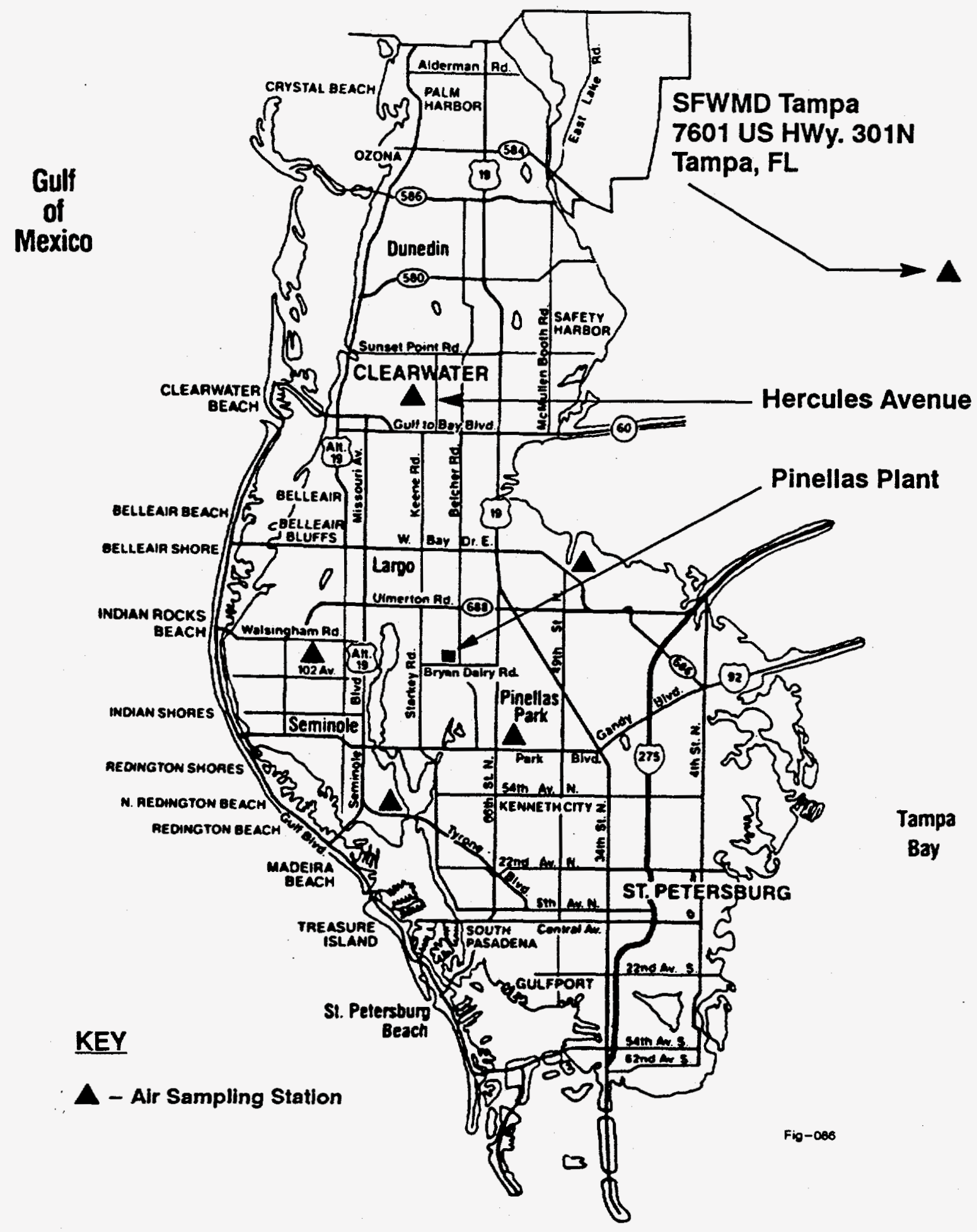

Figure 4-3. Off-Site Air Sampling Station Locations 
Table 4-3. 1994 On-Site Ambient Air Sampling Results

\begin{tabular}{|c|c|c|c|c|}
\hline $\begin{array}{l}\text { Station Number } \\
\text { (see Figure 4-1) }\end{array}$ & Radionuclide & $\begin{array}{l}\text { Sample } \\
\text { Frequency }\end{array}$ & $\begin{array}{l}\text { Annual } \\
\text { Average } \\
\text { Activity, } \\
\mu \mathrm{Ci} / \mathrm{ml}\end{array}$ & $\begin{array}{l}\text { Sampling Station } \\
\text { Detection Limit } \mu \mathrm{Ci} / \mathrm{ml}\end{array}$ \\
\hline 1 & Tritium & Monthly & $2.66 \times 10^{-11}$ & $3.77 \times 10^{-12}$ to $1.24 \times 10^{-11}$ \\
\hline 2 & $\begin{array}{l}\text { Tritium } \\
\text { Pu-238 } \\
\text { Pu-239 }\end{array}$ & $\begin{array}{l}\text { Monthly } \\
\text { Biweekly } \\
\text { Biweekly }\end{array}$ & $\begin{array}{l}3.82 \times 10^{-12} \\
\text { BDL } \\
\text { BDL }\end{array}$ & $\begin{array}{l}3.63 \times 10^{-12} \text { to } 6.16 \times 10^{-12} \\
4.44 \times 10^{-18} \text { to } 1.01 \times 10^{-17} \\
4.44 \times 10^{-18} \text { to } 1.13 \times 10^{-17}\end{array}$ \\
\hline 3 & Tritium & Monthly & $\mathrm{BDL}$ & $2.53 \times 10^{-12}$ to $6.26 \times 10^{-12}$ \\
\hline 4 & $\begin{array}{l}\text { Tritium } \\
\text { Pu-238 } \\
\text { Pu-239 }\end{array}$ & $\begin{array}{l}\text { Monthly } \\
\text { Biweekly } \\
\text { Biweekly }\end{array}$ & $\begin{array}{l}\mathrm{BDL} \\
\mathrm{BDL} \\
\mathrm{BDL}\end{array}$ & $\begin{array}{l}4.48 \times 10^{-12} \text { to } 6.72 \times 10^{-12} \\
1.46 \times 10^{-18} \text { to } 6.92 \times 10^{-18} \\
3.96 \times 10^{-18} \text { to } 1.19 \times 10^{-17}\end{array}$ \\
\hline 5 & Tritium & Monthly & $6.68 \times 10^{-12}$ & $4.04 \times 10^{-12}$ to $2.31 \times 10^{-11}$ \\
\hline 6 & $\begin{array}{l}\text { Tritium } \\
\text { Pu-238 } \\
\text { Pu-239 }\end{array}$ & $\begin{array}{l}\text { Monthly } \\
\text { Biweekly } \\
\text { Biweekly }\end{array}$ & $\begin{array}{c}8.87 \times 10^{-12} \\
\text { BDL } \\
\text { BDL }\end{array}$ & $\begin{array}{l}4.07 \times 10^{-12} \text { to } 8.02 \times 10^{-12} \\
1.65 \times 10^{-18} \text { to } 1.10 \times 10^{-17} \\
1.65 \times 10^{-18} \text { to } 1.21 \times 10^{-17}\end{array}$ \\
\hline 7 & $\begin{array}{l}\text { Tritium } \\
\mathrm{Pu}-238 \\
\mathrm{Pu}-239\end{array}$ & $\begin{array}{l}\text { Monthly } \\
\text { Biweekly } \\
\text { Biweekly }\end{array}$ & $\begin{array}{l}4.81 \times 10^{-12} \\
\text { BDL } \\
\text { BDL }\end{array}$ & $\begin{array}{l}3.79 \times 10^{-12} \text { to } 6.43 \times 10^{-12} \\
1.91 \times 10^{-18} \text { to } 6.29 \times 10^{-18} \\
1.91 \times 10^{-18} \text { to } 1.08 \times 10^{-17}\end{array}$ \\
\hline 8 & Tritium & Monthly & $\mathrm{BDL}$ & $3.37 \times 10^{-12}$ to $4.80 \times 10^{-12}$ \\
\hline 9 & Tritium & Monthly & $5.49 \times 10^{-12}$ & $4.46 \times 10^{-12}$ to $6.76 \times 10^{-12}$ \\
\hline 10 & Tritium & Monthly & $4.82 \times 10^{-12}$ & $4.12 \times 10^{-12}$ to $6.72 \times 10^{-12}$ \\
\hline 11 & Tritium & Monthly & $9.58 \times 10^{-12}$ & $3.78 \times 10^{-12}$ to $6.21 \times 10^{-12}$ \\
\hline HRS & $\begin{array}{l}\text { Tritium } \\
\text { Pu-238 } \\
\text { Pu-239 }\end{array}$ & $\begin{array}{l}\text { Monthly } \\
\text { Biweekly } \\
\text { Biweekly }\end{array}$ & $\begin{array}{c}<1.22 \times 10^{-12} \\
\text { N/A } \\
\text { N/A }\end{array}$ & $\begin{array}{c}1.29 \times 10^{-12} \text { to } 3.14 \times 10^{-12} \\
\text { N/A } \\
\text { N/A }\end{array}$ \\
\hline HRS Standard & \begin{tabular}{|l|} 
Tritium \\
Pu-238 \\
Pu-239
\end{tabular} & & $\begin{array}{c}1.0 \times 10^{-7} \\
2.0 \times 10^{-14} \\
2.0 \times 10^{-14}\end{array}$ & \\
\hline
\end{tabular}

The HRS operates an independent tritium and plutonium air sampling station on site next to the plant's Station 4 located adjacent to the New Directions in Learning (NDL) Child Development and Partnership School (Figure 4-1). The HRS uses the same sampling equipment, but analyzes the samples in their own laboratory. The HRS data is compared with data reported for Pinellas Plant Station 4. 
Table 4-4. 1994 Off-Site Ambient Air Sampling Results

\begin{tabular}{|c|c|c|c|c|}
\hline Station Name & Radionuclide & $\begin{array}{l}\text { Sample } \\
\text { Frequency }\end{array}$ & $\begin{array}{c}\text { Annual Average } \\
\text { Concentration, } \\
\mu \mathrm{Ci} / \mathrm{ml}\end{array}$ & $\begin{array}{c}\mathrm{DL} \\
\mu \mathrm{Ci} / \mathrm{ml}\end{array}$ \\
\hline Civil Defense & $\begin{array}{l}\text { Tritium } \\
\mathrm{Pu}-238 \\
\mathrm{Pu}-239\end{array}$ & $\begin{array}{l}\text { Monthly } \\
\text { Biweekly } \\
\text { Biweekly }\end{array}$ & $\begin{array}{l}\text { BDL } \\
\text { BDL } \\
\text { BDL }\end{array}$ & $\begin{array}{l}4.18 \times 10^{-12} \text { to } 6.6 \times 10^{-12} \\
1.97 \times 10^{-18} \text { to } 7.06 \times 10^{-18} \\
1.37 \times 10^{-18} \text { to } 1.21 \times 10^{-17}\end{array}$ \\
\hline Pinellas Park & \begin{tabular}{|l} 
Tritium \\
Pu-238 \\
Pu-239
\end{tabular} & $\begin{array}{l}\text { Monthly } \\
\text { Biweekly } \\
\text { Biweekly }\end{array}$ & $\begin{array}{l}\text { BDL } \\
\text { BDL } \\
\text { BDL }\end{array}$ & $\begin{array}{l}4.04 \times 10^{-12} \text { to } 1.15 \times 10^{-11} \\
4.23 \times 10^{-18} \text { to } 8.72 \times 10^{-18} \\
4.23 \times 10^{-18} \text { to } 1.19 \times 10^{-17}\end{array}$ \\
\hline Bay Pines & \begin{tabular}{|l} 
Tritium \\
$\mathrm{Pu}-238$ \\
$\mathrm{Pu}-239$
\end{tabular} & $\begin{array}{l}\text { Monthly } \\
\text { Biweekly } \\
\text { Biweekly }\end{array}$ & $\begin{array}{l}\text { BDL } \\
\text { BDL } \\
\text { BDL }\end{array}$ & $\begin{array}{l}2.57 \times 10^{-12} \text { to } 9.23 \times 10^{-12} \\
5.94 \times 10^{-18} \text { to } 1.19 \times 10^{-17} \\
5.31 \times 10^{-18} \text { to } 1.06 \times 10^{-17}\end{array}$ \\
\hline Walsingham & \begin{tabular}{|l|} 
Tritium \\
Pu-238 \\
Pu-239
\end{tabular} & \begin{tabular}{|l} 
Monthly \\
Biweekly \\
Biweekly
\end{tabular} & $\begin{array}{l}\text { BDL } \\
\text { BDL } \\
\text { BDL }\end{array}$ & $\begin{array}{l}3.53 \times 10^{-12} \text { to } 8.38 \times 10^{-12} \\
1.62 \times 10^{-18} \text { to } 6.17 \times 10^{-18} \\
4.41 \times 10^{-18} \text { to } 1.06 \times 10^{-17}\end{array}$ \\
\hline Clearwater & Tritium & Monthly & BDL & $4.59 \times 10^{-12}$ to $6.05 \times 10^{-12}$ \\
\hline SWFWMD & Tritium & Monthly & $\overline{B D L}$ & $4.17 \times 10^{-12}$ to $2.28 \times 10^{-11}$ \\
\hline Manatee & Tritium & Monthly & BDL & $4.53 \times 10^{-12}$ to $6.21 \times 10^{-12}$ \\
\hline
\end{tabular}

\subsubsection{Water}

\section{Surface Water}

With the right meteorological conditions, airborne tritium can be deposited into surface waters. The Pinellas Plant samples both on-site and off-site surface waters regularly and analyzes the samples for tritium to determine the extent of this potential deposition of tritium. The plant samples the South and East on-site stormwater retention ponds and the West on-site stormwater detention pond weekly. The South and East ponds can overflow into the Pinellas County Storm Sewer System. The water entering the storm sewer system combines with run-off from other areas of the county and eventually empties into Boca Ciega Bay. The West Pond outfall was plugged and has not discharged since 1972. The on-site ponds are identified in Figure 4-1.

Twenty-six off-site surface water locations are sampled quarterly and analyzed for tritium. The locations are shown in Figure 4-4. Table 4-5 is a summary of on-site surface water sampling data for 1994 . The results show very low concentrations of tritium in the on-site ponds, with most samples at or below the detection limit. 
Measurements of tritium in all off-site surface water samples for 1994 were at or below the detection limit. In all samples analyzed, the concentrations were orders of magnitude below the DOE DCG standard for drinking water of $2.0 \times 10^{3} \mathrm{pCi} / \mathrm{ml}(74 \mathrm{~Bq} / \mathrm{ml})$ and EPA drinking water standard of $20 \mathrm{pCi} / \mathrm{ml}(0.74 \mathrm{~Bq} / \mathrm{ml})$.

The HRS established a surface water sampling and analysis program at the plant. The HRS samples and analyzes the on-site ponds and various off-site surface waters surrounding the plant for tritium. The on-site pond tritium concentrations detected by the HRS, reported in Table 4-5, are compared with data collected and analyzed by the plant. The HRS and the plant sample off-site surface waters in different locations; therefore, the results are not directly comparable.

Table 4-5. On-Site Surface Water Tritium Concentrations

\begin{tabular}{|c|c|c|}
\hline On-site Location & $\begin{array}{c}\text { Annual Average } \\
\text { Concentration, } \\
\text { pCi/ml }\end{array}$ & $\begin{array}{l}\text { Detection Limit } \\
\text { Range, } \mathbf{p C i} / \mathbf{m l}\end{array}$ \\
\hline Pinellas Plant & & \\
\hline East Pond & $\mathrm{BDL}$ & 0.32 to 0.43 \\
\hline West Pond & $\mathrm{BDL}$ & 0.32 to 0.43 \\
\hline South Pond & $\mathrm{BDL}$ & 0.32 to 0.43 \\
\hline HRS Samples & & \\
\hline East Pond & $<0.454$ & 0.127 to 0.142 \\
\hline West Pond & $<0.192$ & 0.127 to 0.142 \\
\hline South Pond & $<0.188$ & 0.127 to 0.142 \\
\hline N/A = Not available at time of printing & \\
\hline
\end{tabular}




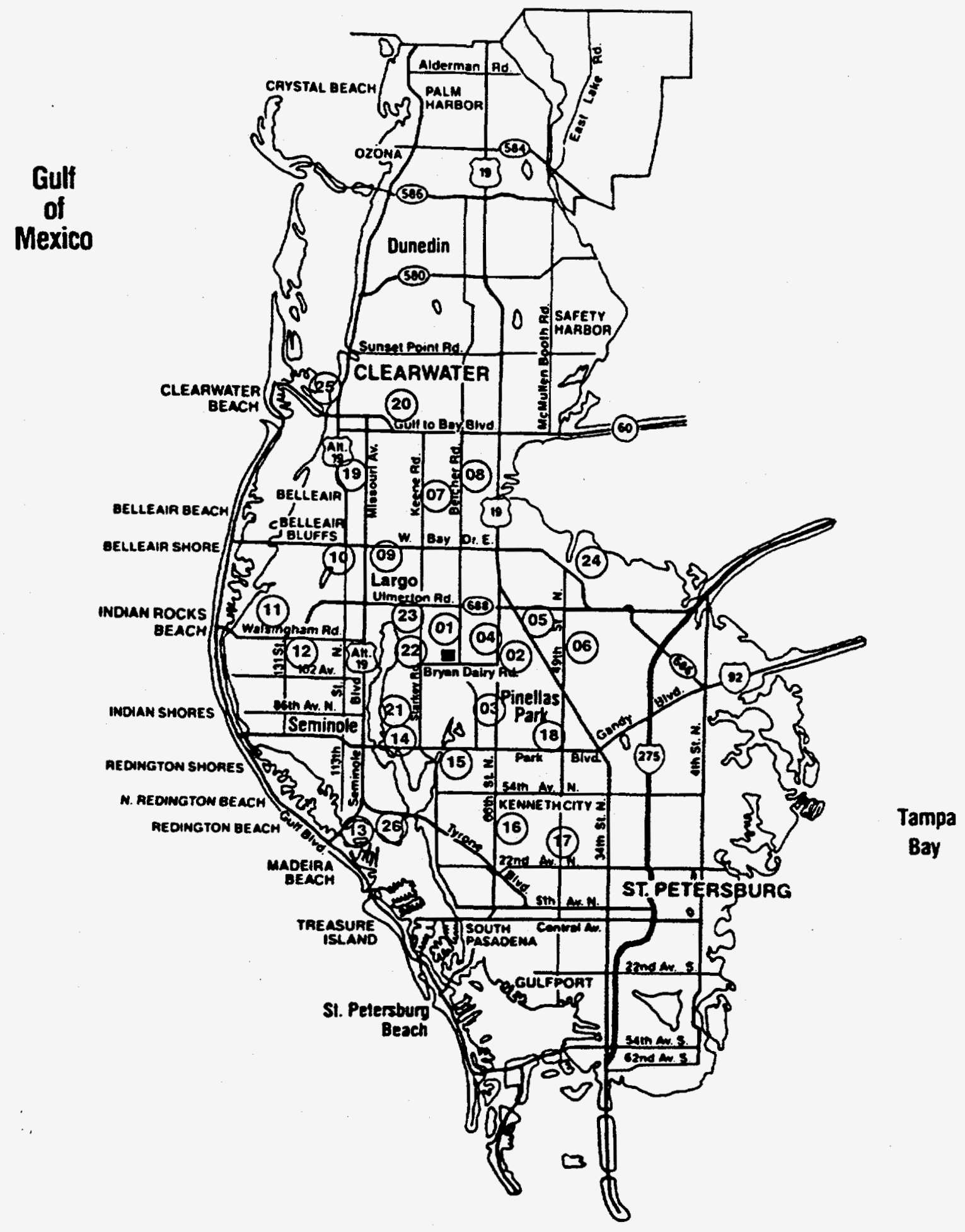

Figure 4-4. Off-Site Surface Water Sampling Locations 


\section{Groundwater}

Tritium has been detected in the Pinellas Plant groundwater. During 1994, the plant analyzed 428 samples for tritium from monitoring wells in the surficial and Floridan aquifers as part of the Pinellas Plant Groundwater Monitoring Program. The highest concentration of tritium detected in samples from the surficial aquifer was $3.65 \mathrm{pCi} / \mathrm{ml}$ which is significantly below the SDWA Maximum Contaminant Level (MCL) of $20 \mathrm{pCi} / \mathrm{ml}$. Most surficial aquifer samples were reported to be lower than the minimum detection limit. Analysis of samples from the Floridan aquifer revealed no detectable levels of tritium. The plant will continue to analyze groundwater from selected wells in both aquifers for tritium on a quarterly basis.

\subsubsection{Soil}

Soil from two on-site and four off-site locations were collected in 1994 and analyzed for plutonium even though the last plutonium heat sources were removed from the site in February 1991. Soil samples are selected annually from a master list of sites as shown in Table 4-6. The on- and off-site soil sampling locations are shown in Figures 4-5 and 4-6. Soil samples down to a depth of approximately 15 centimeters are collected from each sampling location. All of the soil samples analyzed in 1994 had $\mathrm{Pu}-238$ levels below the detection limit which ranged from $2.58 \times 10^{-3}$ to $6.40 \times 10^{-3} \mathrm{pCi} / \mathrm{g}$.

Table 4-6. Soil Sample Location Schedule

\begin{tabular}{|l|l|l|l|}
\hline Year & On-Site Locations & Off-Site Locations \\
\hline 1987 & GE-05 GE-11 & PC-03 PC-05 PC-07 PC-16 \\
\hline 1988 & GE-04 GE-08 & PC-02 PC-06 PC-13 PC-14 \\
\hline 1989 & GE-03 GE-09 & PC-04 PC-09 PC-11 PC-15 \\
\hline 1990 & GE-10 GE-14 & PC-01 PC-08 PC-10 PC-12 \\
\hline 1991 & GE-12 GE-13 & PC-03 PC-05 PC-07 PC-16 \\
\hline 1992 & GE-01 GE-06 & PC-02 PC-06 PC-13 PC-14 \\
\hline 1993 & GE-02 GE-07 HRS-01 HRS-02 & PC-04 PC-09 PC-11 PC-15 \\
\hline 1994 & GE-05 GE-11 & PC-01 PC-08 PC-10 PC-12 \\
\hline 1995 & GE-04 GE-08 & PC-03 PC-05 PC-07 PC-16 \\
\hline 1996 & GE-03 GE-09 & PC-02 PC-06 PC-13 PC-14 \\
\hline 1997 & GE-10 GE-14 & PC-04 PC-09 PC-11 PC-15 \\
\hline
\end{tabular}


'py ґәчगә

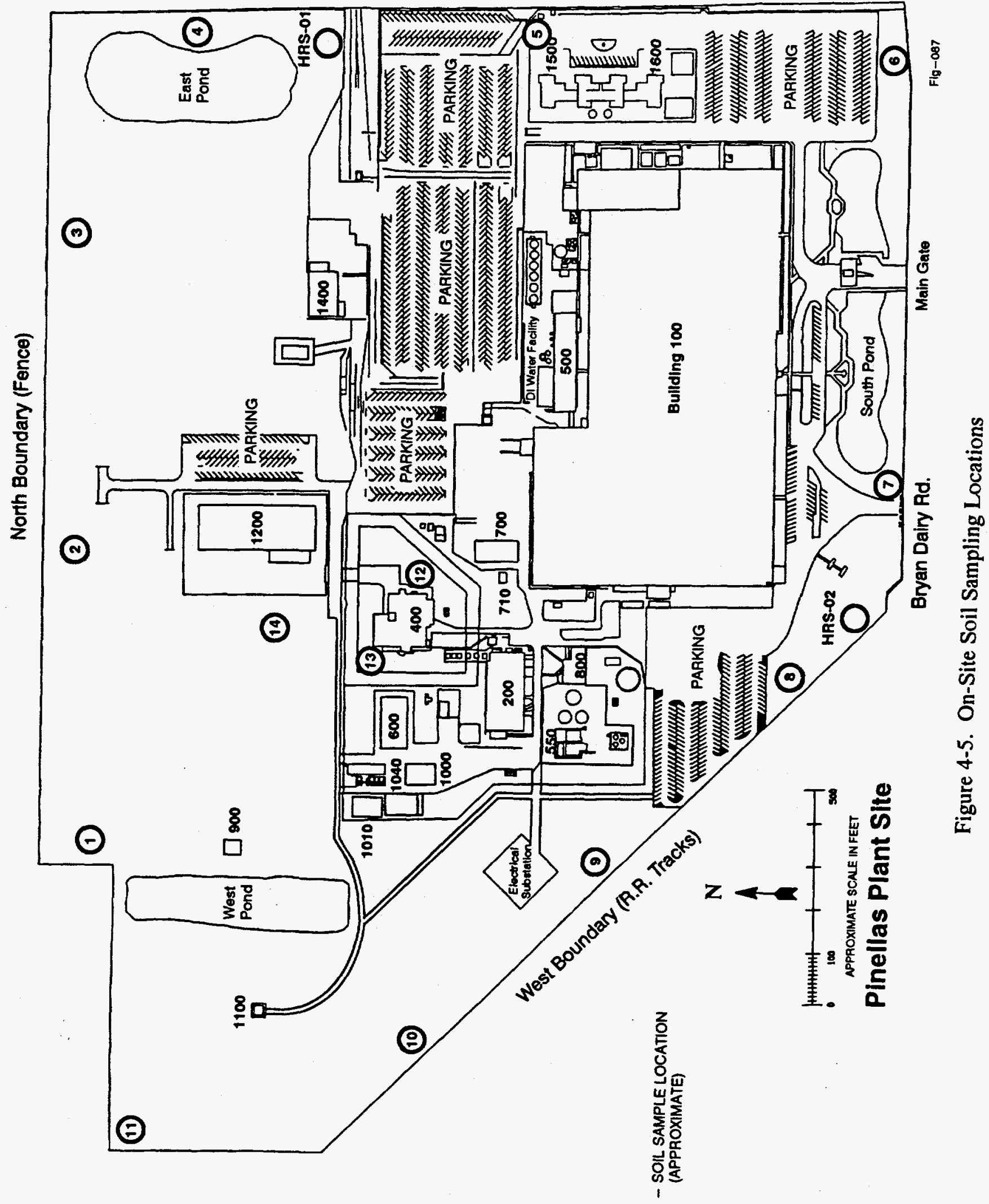

() 


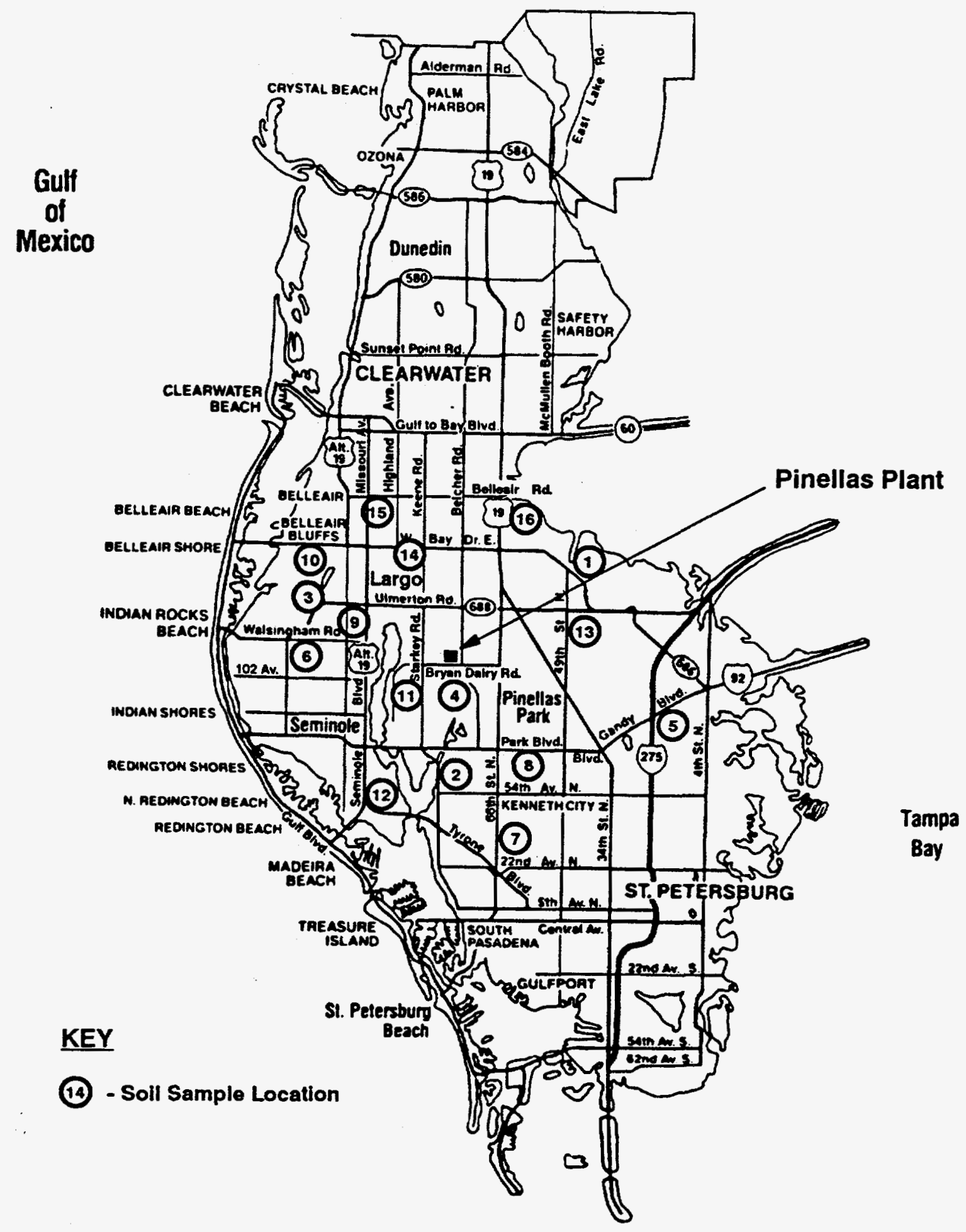

Figure 4-6. Off-Site Soil Sampling Locations 
The plant observed Pu-239 above the detection limit in five soil samples collected in 1994. Pu-239 was distributed throughout the world during above-ground nuclear testing in the 1950s The total activity of $\mathrm{Pu}-239$ at the plant during 1994 , ranged from $6.15 \times 10^{-3}$ to $1.02 \times 10^{-2} \mathrm{pCi} / \mathrm{g}$. The detection limit ranged from $2.38 \times 10^{-3}$ to $3.96 \times 10^{-3} \mathrm{pCi} / \mathrm{g}$. Pinellas Plant RTG plutonium was composed of approximately $80 \% \mathrm{Pu}-238$ and $16 \%$ $\mathrm{Pu}-239$ and would be found in that ratio if dispersed into the environment. Plant personnel have never observed any $\mathrm{Pu}-238$ in environmental samples.

\subsection{Evaluation of Potential Dose to the Public}

\subsubsection{Dose Standards}

Pinellas Plant requirements for radiation protection of the public and the environment are promulgated by DOE 5400.5 [Ref. 3]. These requirements set a cumulative public dose limit for all DOE sources of radiation for all exposure modes at $100 \mathrm{mrem} / \mathrm{yr}(1.0 \mathrm{mSv})$ effective dose equivalent. The order also incorporates the EPA $10 \mathrm{mrem} / \mathrm{yr}(0.1 \mathrm{mSv})$ limits for atmospheric pathways [Ref. 8] which applies to the Pinellas Plant. The exposure limit for drinking water for all DOE sources of radionuclides is $4 \mathrm{mrem} / \mathrm{yr}(0.04 \mathrm{mSv})$.

DOE 5400.5 presents a DCG for each radionuclide. DCG values are listed as reference values for each of three modes of exposure to the radionuclide; inhalation, absorption, and ingestion DCG levels are values that equate to the $100 \mathrm{mrem} / \mathrm{yr}(1.0 \mathrm{mSv})$ dose limits listed in DOE 5400.5.

The EPA standard [Ref. 8] requires continuous monitoring of sources having a potential to discharge radionuclides into the air in quantities that cause an effective dose equivalent in excess of $1 \%$ of the standard, or $0.1 \mathrm{mrem} / \mathrm{yr}$. The plant uses two computer codes to verify compliance with radionuclide emission standards. The COMPLY code is used to verify that potential worst-case plant emissions are below $1 \%$ of the $10 \mathrm{mrem} / \mathrm{yr}$ EPA standard. The CAP88-PC code is used to verify that actual annual emissions do not result in a dose to the public greater than the $10 \mathrm{mrem} / \mathrm{yr}$ standard. CAP88-PC was used for the 1994 Radionuclide Air Emissions Annual Report scheduled for submittal to the EPA in June 1995.

\subsubsection{Dose to the Public Due to Naturally Occurring Radiation}

Independent of any DOE sources of radiation, the population receives an annual radiation dose from five natural sources as follows: 


\section{Cosmic Radiation from Outer Space}

Cosmic rays are extremely penetrating. The dose varies with altitude. The average annual dose equivalent to people in the United States is 28 mrem $(0.28 \mathrm{mSv})$.

\section{External Gamma Radiation}

Naturally occurring radionuclides produce external gamma exposures. The major contributors are radon and its isotopes, which arise from the natural decay of uranium and thorium deposited in rocks and potassium-40. Average annual dose varies from $16 \mathrm{mrem}(0.16 \mathrm{mSv})$ at the Atlantic Coast to $63 \mathrm{mrem}(0.63 \mathrm{mSv})$ at the eastern slopes of the Rocky Mountains.

\section{Internal Radiation}

The primary contributors to the internal radiation dose are potassium- 40 , polonium-210, radium-226, and carbon-14, which are ingested in foodstuffs, and radon-222 and its daughters, which are inhaled. These natural radionuclides contribute an average annual dose of 200 mrem (2.0 mSv).

\section{Consumer Products}

Radiation occurs incidentally from the product function of consumer goods, such as televisions, and provides an annual average dose of 612 mrem ( 0.06 to $0.12 \mathrm{mSv}$ ) to the average member of the public.

\section{Medical Diagnosis and Therapy}

The average annual dose equivalent to all individuals from all medical examinations is $53 \mathrm{mrem}(0.53 \mathrm{mSv})$.

The total dose from these sources of naturally occurring radiation is approximately 360 mrem ( $3.6 \mathrm{mSv}$ ) per year. When compared to this dose, the average dose to a member of the population within a 50-mile radius resulting from plant operations is extremely small, 0.000038 $\mathrm{mrem} / \mathrm{yr}$.

\subsubsection{Potential Dose to the Population Within 50 Miles of the Plant Site}

Pinellas Plant personnel used the EPA-approved CAP88-PC code, with actual 1993 total emissions of tritium and $\mathrm{Kr}-85$, to determine the radiation dose to all individuals residing within 50 miles of the plant site. This dose is expressed in person-rem. For example, if 1,000 people 
resided in the area and each received a radiation dose of $1 \mathrm{rem}$, the population dose would be 1000 person-rem. Based on the 1990 census, the population within 50 miles of the plant is estimated to be $2,529,870$. The calculated 1994 radiation exposure to the average member of the population is $3.8 \times 10^{-5} \mathrm{mrem} / \mathrm{yr}$ or $9.71 \times 10^{-2}$ person-rem/yr for the population. The 1994 population exposure is slightly higher than 1993, $4.3 \times 10^{-2}$ person-rem. This is due to slightly higher tritium emissions at the plant. The 1994 exposure is not significantly higher than 1993. Slight increases are due in part to higher tritium emissions in 1994. This increase in tritium emissions was largely due to the increase in production to meet the DOE goal.

\subsubsection{Potential Dose to the Most Exposed Individual of the Public}

The potential dose to the most exposed individual of the public was also determined using the CAP88-PC computer code and actual 1994 emissions of tritium and $\mathrm{Kr}-85$. The computer code assumes that the member of the public remains at the residential location closest to the plant continuously throughout the year and ingests foodstuffs that are locally grown. These are very conservative assumptions since Pinellas County is very urban and most foodstuffs are imported from outside the county. The results of the modeling for three nearby locations are presented in Table 4-7 and show that plant emissions result in estimated dose to the public well below EPA and DOE dose limits.

Table 4-7. 1994 CAP88-PC Dose Calculations

\begin{tabular}{|l|l|l|c|}
\hline \multicolumn{1}{|c|}{ Description } & \multicolumn{1}{|c|}{ Location } & $\begin{array}{c}\text { EPA and } \\
\text { EOE } \\
\text { Equivalent, mrem/yr } \\
\text { (mSv/yr) }\end{array}$ & $\begin{array}{c}\text { Dose } \\
\text { Limits } \\
(\mathrm{mrem} / \mathrm{yr})\end{array}$ \\
\hline Apartment Bldg. & 620 meters WSW of site & $4.8 \times 10^{-3}\left(4.8 \times 10^{-5}\right)$ & 10.0 \\
\hline Apartment Bldg. & 730 meters NNE of site & $3.9 \times 10^{-3}\left(3.9 \times 10^{-5}\right)$ & 10.0 \\
\hline House with pool & 1,040 meters NW of site & $3.9 \times 10^{-3}\left(3.9 \times 10^{-5}\right)$ & 10.0 \\
\hline NDL School & 130 meters E of site & $3.3 \times 10^{-3}\left(3.3 \times 10^{-5}\right)$ & 10.0 \\
\hline $\begin{array}{l}\text { Most Exposed } \\
\text { Individual }\end{array}$ & 450 meters W of site & $5.6 \times 10^{-3}\left(5.6 \times 10^{-5}\right)$ & 10.0 \\
\hline
\end{tabular}

As determined by the model, the location of the most exposed individual (MEI) is 450 meters west of the Building 100 main stack; however, there are no full-time residents at this location. The doses listed in the table include all radionuclides and all pathways. 


\subsubsection{Potential Dose Due to Plutonium}

Ongoing monitoring results continue to show no plutonium from RTG operations was released to the environment, so there is no radiation dose to the public. Because no plutonium was ever released from the plant to the environment, plutonium dose pathway is not considered in the CAP88-PC dose assessment model.

\subsubsection{Minor Source Compliance}

The EPA requires continuous monitoring of sources having a potential to discharge radionuclides into the air in quantities that cause an effective dose equivalent greater than $1 \%(0.1 \mathrm{mrem} / \mathrm{yr})$ of the $10 \mathrm{mrem} / \mathrm{yr}$ standard. The plant used the COMPLY computer code in 1994 to calculate the dose to the most exposed individual of the public under a set of worst-case assumptions, rather than the actual emissions data. In the worst-case, emissions controls, including the tritium recovery system, are not functioning, and all of the tritium and $\mathrm{Kr}-85$ used during the year, 822.8 curies and 100 curies, respectively, are discharged. The results of the model show that even under these circumstances, the most exposed individual of the public would receive a dose of $5.1 \times 10^{-2} \mathrm{mrem} / \mathrm{yr}$. $\left(5.1 \times 10^{-4} \mathrm{mSv} / \mathrm{year}\right)$, an amount under $1 \%$ of the standard. The plant is therefore not required to monitor continuously for tritium. As a best management practice, however, the plant continuously monitors the tritium and $\mathrm{Kr}-85$ emissions and the flowrate of the four radiological exhaust stacks, as described in this report.

\subsection{Unplanned Releases and Environmental Occurrences}

On March 23, 1994, an approximately 10-foot section of a sampling line from the duplicate main stack radiological sampling system was cut and removed. This copper pipe provides a sample of stack air to a duplicate sampling system to quantify tritium emissions. This duplicate sampling system runs in parallel with the main sampling system. The main sampling system was not affected by this occurrence and tritium emissions continued to be monitored by the primary sampling system. A service request was issued to Facilities Maintenance to immediately reconnect the removed piping to return the duplicate sampling system to operational status.

On July 22, 1994, approximately 4 curies of tritium were released to the main stack during leak checking of tritium processing equipment. The release was quantified by the flow through ionization chamber and the daily and monthly silica gel columns. Dispersion modeling using the HOTSPOT computer model was conducted and the total external EDE at the fenceline was estimated at $1.2 \times 10^{-2}$ mrem. Administrative controls were put in place to prevent this release from recurring. 
On October 6, 1994, the air sampling pumps used for providing air from the main radiological exhaust stack to the tritium stack monitoring and sampling systems were deactivated. Health Physics personnel observed that the strip chart recorder to the tritium stack monitoring system did not indicate normal periodic peaks from routine tritium operations. Although the electronics of the tritium stack monitoring system were functioning, Health Physics discovered no sample air flow going through the Kanne chamber. Lack of air flow from the radiological stack also affected the tritium sampling system by not providing continuous air flow. All process and room Kanne chamber air monitors in the main tritium processing areas were functioning normally and no alarms occurred during the day, indicating that a tritium release had not occurred. When performing corrective maintenance, technicians had shut off the main power to the stack sampling pumps. The corrective action included adding separate power disconnects, so that the sampling pumps could remain operating during maintenance on the sampling system electronics.

\subsection{ALARA Program}

The Pinellas Plant maintains an active ALARA program for environmental releases of radioactive material that sets emission goals significantly lower than the amounts permitted by regulations. In 1994, the plant remained below all ALARA goals for radionuclide releases. Tritium and $\mathrm{Kr}-85$ releases from the plant through the stacks and the tritium release to the sewer system were far below the amounts permitted.

ALARA goals for CY1994 included the following:

a) Minimizing releases of $\mathrm{Kr}-85$ to less than $\mathbf{4 0}$ curies

b) Limiting tritium releases to less than 75 curies

c) Limiting tritium releases to the POTW to less than 2 curies 
This page left blank intentionally. 


\subsection{ENVIRONMENTAL NONRADIOLOGICAL PROGRAM INFORMATION}

\subsection{Atmospheric Nonradiological Emissions}

The Pinellas Plant nonradiological air emissions are regulated under the Air Operating Permit, AO52-233355 [Ref. 15]. The majority of emissions from the Pinellas Plant are from $V O C / O C$ resulting from parts cleaning activities at the plant. Total emissions of $\mathrm{VOC} / \mathrm{OC}$ are restricted to 41.1 tons per year. Total VOC/OC emissions for CY1994 were approximately 11.5 tons, well below permit levels. Table 5-1 provides the actual emissions levels for CY1994. Figure 5-1 shows the actual compound usage for CY1994.

Table 5-1. 1994 Actual Emissions

\begin{tabular}{|l|c|}
\hline \multicolumn{1}{|c|}{ Compound } & Amount \\
\hline Acetone & $1,249.4$ \\
\hline Amyl Acetate & 249.0 \\
\hline Ethanol & $6,451.5$ \\
\hline Isopropyl Alcohol & 315.6 \\
\hline Methyl Alcohol & 384.5 \\
\hline Methylene Chloride & $3,073.6$ \\
\hline Other Misc VOCs & 58.0 \\
\hline Perfluorocompounds & $2,235.4$ \\
\hline Trichloroethane & $3,554.4$ \\
\hline Trichloroethylene & $3,459.9$ \\
\hline Trichlorotrifluoroethane & $2,005.3$ \\
\hline Total - pounds & $23,036.6$ \\
\hline Total - tons & $\mathbf{1 1 . 5}$ \\
\hline
\end{tabular}




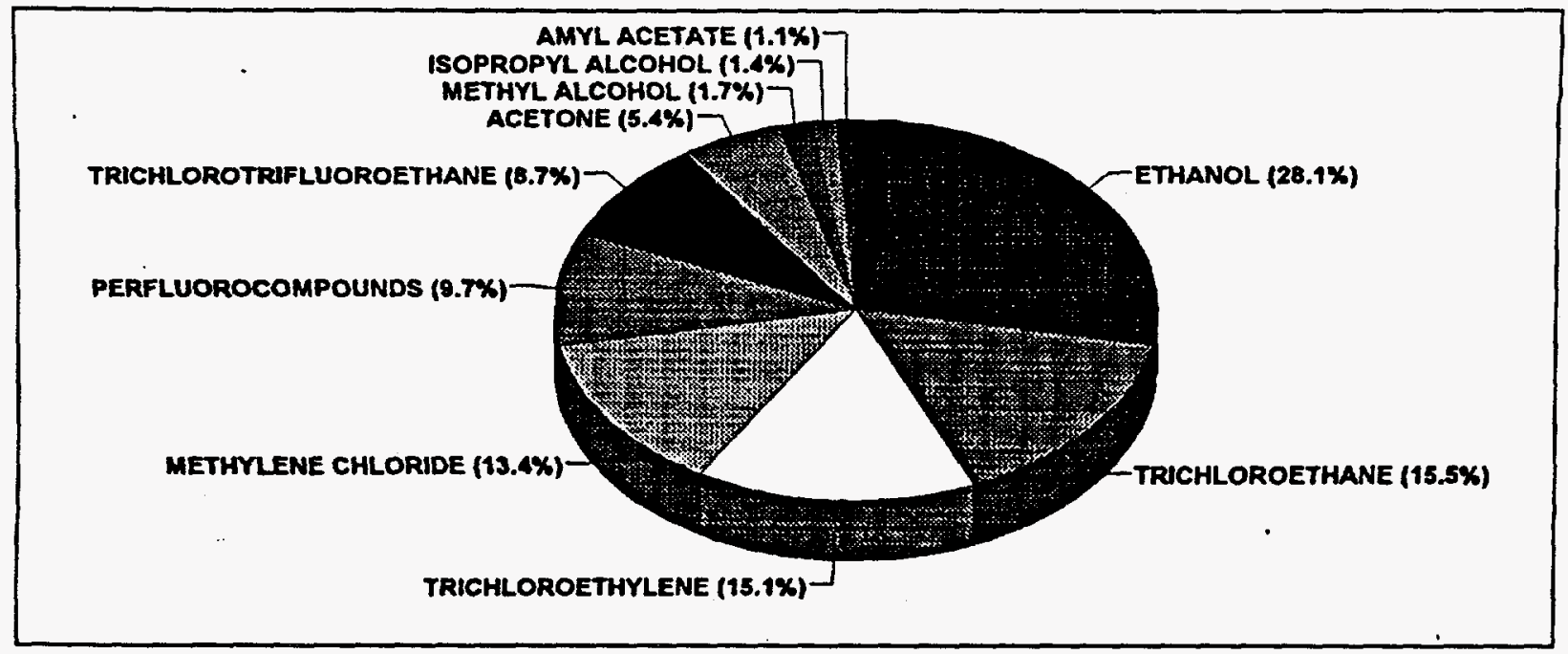

Figure 5-1. Pinellas Plant Actual 1994 VOC/OC Emissions

\subsection{Water}

\subsubsection{Wastewater}

Wastewater consisting of sanitary sewage and pH-neutralized industrial wastewater discharged from the IWNF to the PCSS is continuously sampled and analyzed for the parameters specified in the plant's Industrial Wastewater Discharge Permit, 153-IE [Ref. 10]. The samples for metals, BOD, and TSS are collected by PCSS-approved automatic samplers located in Building 550 at the IWNF (Figure 5-2). Samples for cyanide and TTO are grab samples collected directly from the industrial and combined waste streams at the IWNF. The sample bottles are identified on the chain-of-custody document and delivered to the appropriate in-house laboratory for analysis. The QA program for these samples is described in Section 7.

The plant reviews analytical results immediately to determine if they are within applicable control limits and are below the permit limits. The Pinellas Plant maintains trend charts to indicate when permit limits are being approached. The plant proactively implements corrective actions to prevent exceeding permit limits. Any value exceeding permit limits is reported to DOE and to the industrial program manager at the PCSS.

Figure 5-3 shows the results for the combined waste stream samples collected weekly and analyzed for metals. Only copper and zinc are above detection limits in the wastewater. The figure shows the zinc concentration is at consistently low levels. The copper concentration is slightly more variable; however, it is still below permit limits. 
North Boundary (Fence)

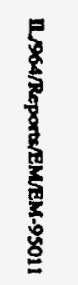

$\tilde{\omega}$

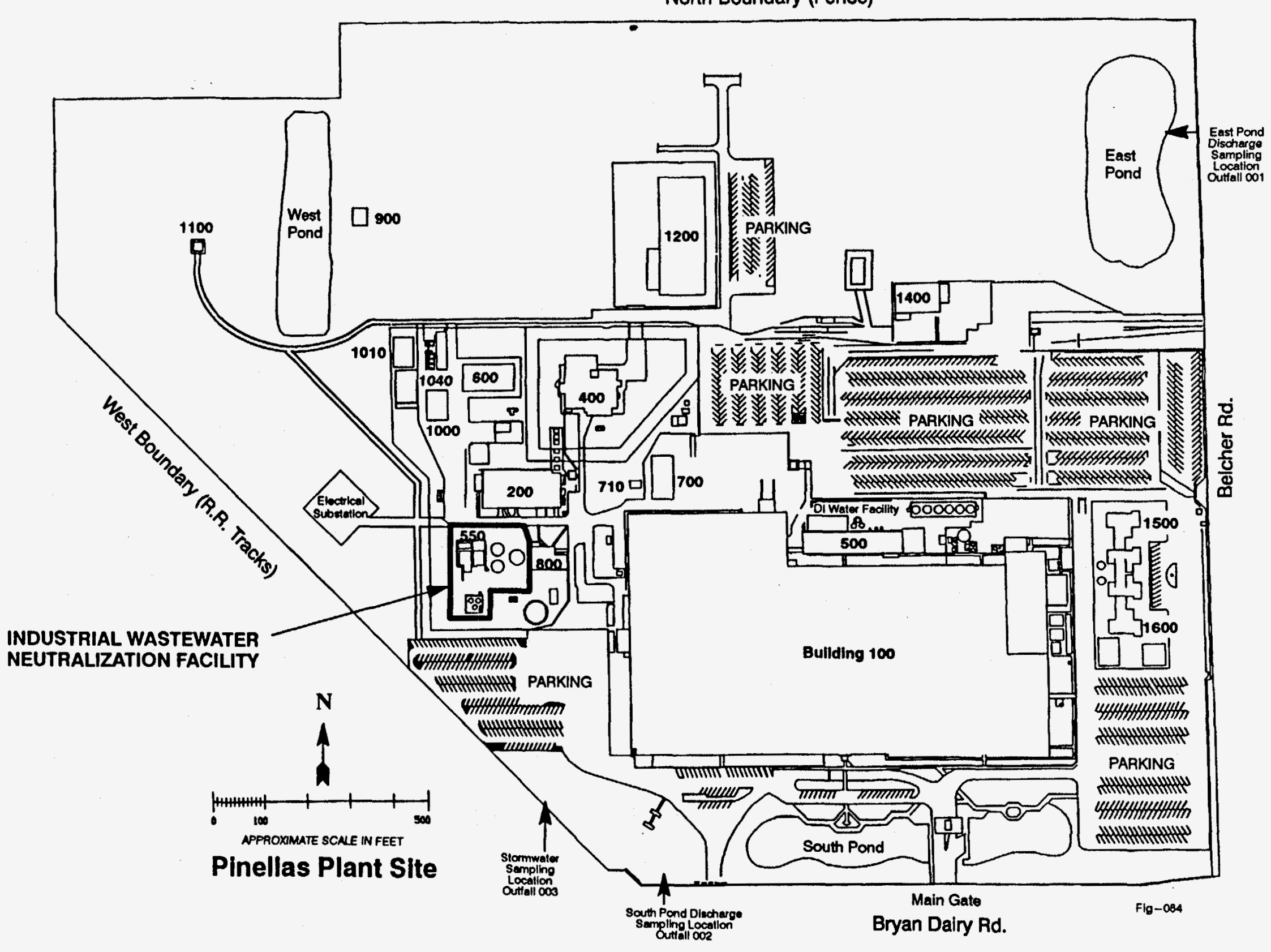

Figure 5-2. Nonradiological Liquid Effluent Sampling Locations, 1994 


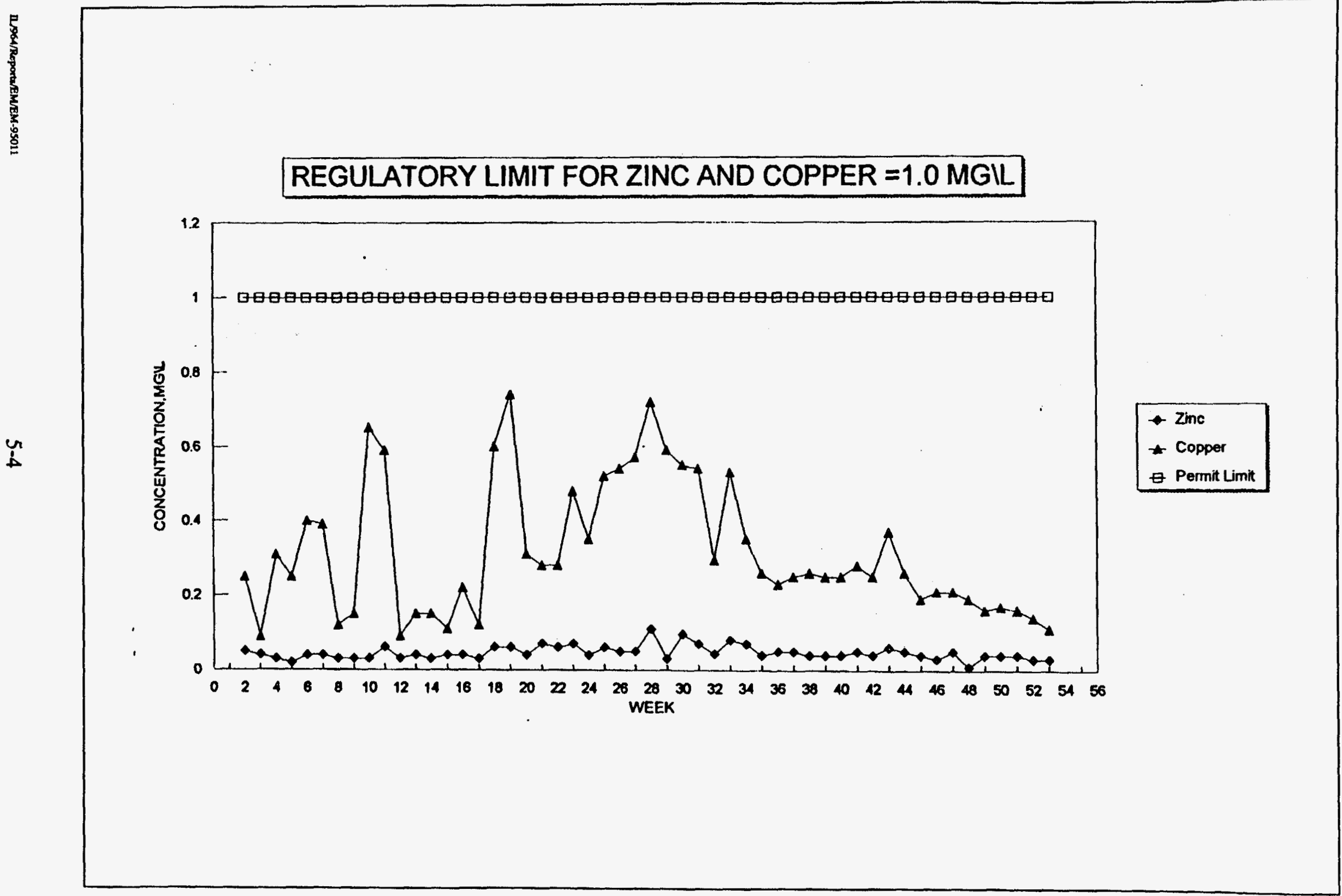

Figure 5-3. Regulated Liquid Effluent Above Detection Limit, 1994 
The Pinellas Plant reports routine monitoring results monthly to DOE and the PCSS Industrial Program Manager. Table 5-2 summarizes the analyses performed on the combined waste stream discharged from the site in 1994.

Table 5-2. Combined Nonradiological Liquid Effluent Analysis Results, 1994

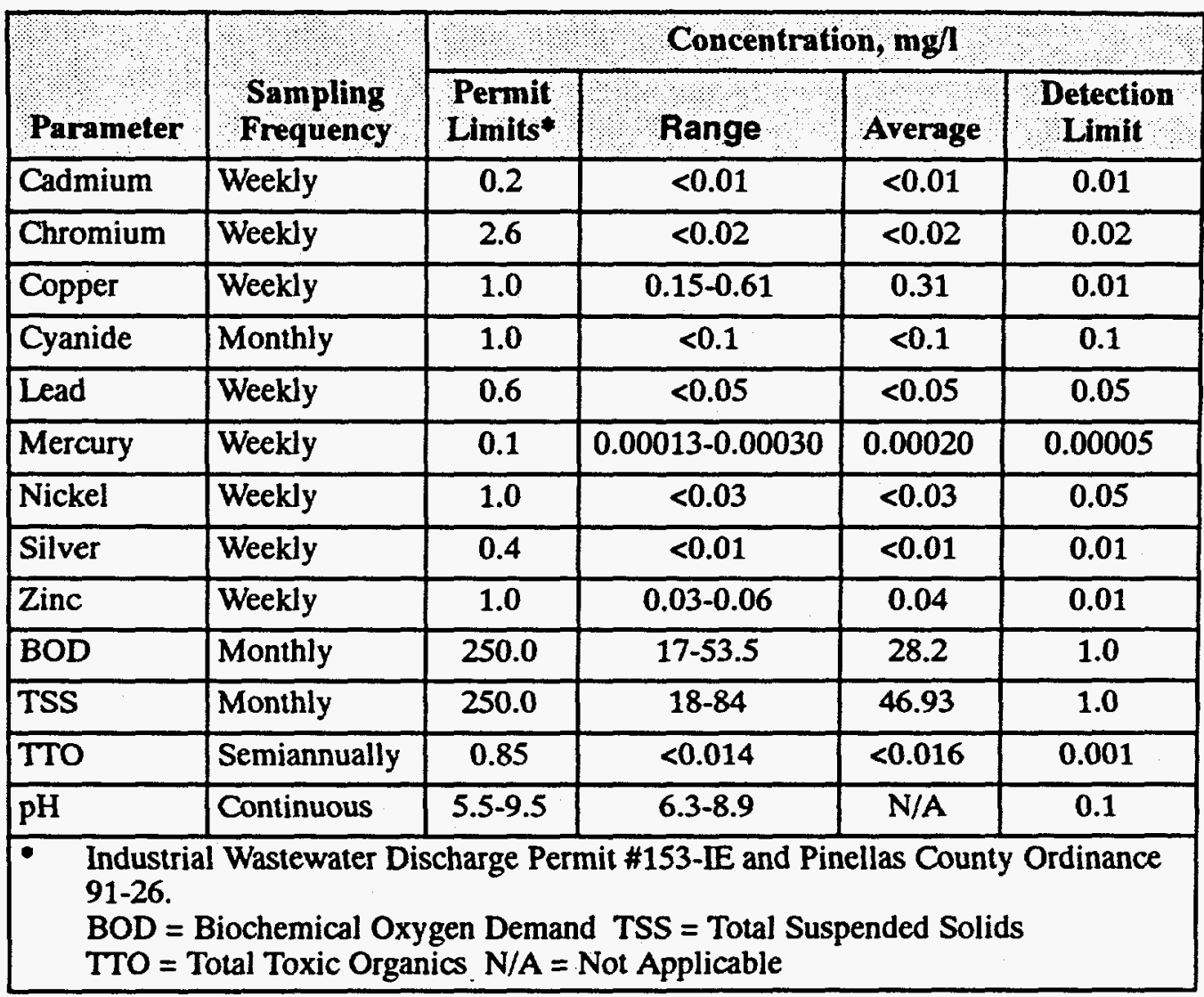

All concentrations are in $\mathrm{mg} / \mathrm{l}$ except $\mathrm{pH}$, which is measured in $\mathrm{pH}$ units. Compared with the 1993 data, the copper, zinc, BOD, and TSS levels are lower. The TTO was slightly higher than last year's figures. There were no instances in which the plant exceeded permitted levels in 1994.

The PCSS maintains a secured sampling station on the Pinellas Plant site. Samples of the plant's combined effluent from this station are collected on an irregular, unannounced basis and analyzed by the county to verify compliance with the permit. After samples are collected, the plant obtains split samples from county personnel to compare results. Samples were collected and analyzed by the county on six occasions in 1994, with the results shown in Table 5-3. The samples were analyzed by the county and Specialty Components, and in both cases, the parameters were below permit limits. 


\begin{tabular}{|c|c|c|c|c|c|c|c|}
\hline \multirow{3}{*}{$\begin{array}{l}\text { Sample } \\
\text { Date } \\
\text { Parameter }\end{array}$} & \multicolumn{7}{|c|}{ Concentration, $\mathrm{mg} / \mathrm{l}$} \\
\hline & \multicolumn{2}{|c|}{ February 23, 1994} & \multicolumn{2}{|c|}{ July 13, 1994} & \multicolumn{2}{|c|}{ October 18, 1994} & \multirow[b]{2}{*}{$\begin{array}{l}\text { Permit } \\
\text { Limits }\end{array}$} \\
\hline & PCSS Result & Plant Result & PCSS Result & Plant Result & PCSS Result & Plant Result & \\
\hline Cadmium & $<0.010$ & $<0.01$ & $<0.010$ & $<0.01$ & $<0.005$ & $<0.01$ & 0.2 \\
\hline Chromium & $<0.050$ & $<0.02$ & $<0.050$ & $<0.05$ & $<0.050$ & $<0.03$ & 2.6 \\
\hline Copper & 0.177 & 0.37 & 0.157 & 0.15 & 0.191 & 0.21 & 1.0 \\
\hline Lead & $<.200$ & $<0.05$ & $<0.150$ & $<0.05$ & $<0.100$ & $<0.05$ & 0.6 \\
\hline Nickel & $<0.050$ & $<0.05$ & $<0.050$ & $<0.03$ & $<0.050$ & $<0.03$ & 1.0 \\
\hline Silver & 0.044 & $<0.01$ & $<0.020$ & $<0.01$ & $<0.020$ & $<0.01$ & 0.4 \\
\hline Zinc & 0.051 & 0.06 & 0.050 & 0.03 & 0.063 & 0.09 & 1.0 \\
\hline pH (mean) & 7.22 & 7.6 & 7.3 & 7.4 & 8.08 & 7.5 & $5.5-9.5$ \\
\hline Cyanide & N/A & N/A & N/A & N/A & N/A & $\mathbf{N} / \mathbf{A}$ & 1.0 \\
\hline BOD & N/A & N/A & N/A & N/A & 100 & 59 & 250 \\
\hline TSS & N/A & N/A & N/A & N/A & 152 & 168 & 250 \\
\hline \multicolumn{8}{|c|}{$\begin{array}{l}\text { Industral Wastewater Discharge Permit \#153-IE and Pinellas County Ordinance 91-26. } \\
\text { N/A = Not Analyzed } \\
\text { All units in milligrams per liter (mg/) except pH. }\end{array}$} \\
\hline
\end{tabular}




\subsubsection{Surface Water}

In 1994, the plant sampled the three on-site ponds quarterly for VOCs and semiannually for metals. Laboratory analytical results for VOCs were below the analytical detection limit. Results for manganese were at or below the standard of $.1 \mathrm{mg} /$. The only metal parameter detected above standards was iron. It exceeded the standard in both sampling periods and was attributed to natural environmental conditions. All other metal parameters remained below the detection level.

\subsubsection{Stormwater}

The Pinellas Plant sampled and analyzed stormwater discharge from two outfalls and submitted an individual permit application for stormwater discharges associated with industrial activity in September 1992. In 1993, the plant discovered an additional existing outfall as a result of the dye-tracer study of the storm drain system. The discharge from this outfall was sampled and analyzed during two storm events in 1993 and the original permit application was revised and submitted to EPA. A revised permit application was sent in April 1994. The plant has not yet received an NPDES stormwater discharge permit from the EPA.

\subsection{Environmental Occurrences}

The Pinellas Plant had no environmental releases that resulted in the violation of any permit limits during 1994 . There were, however, two occurrences that resulted in regulatory agency notification.

On July 12,1994 , the results of the weekly wastewater sample for metals indicated a copper concentration of $1.34 \mathrm{mg} /$, which slightly exceeded the 1.05 $\mathrm{mg} / \mathrm{l}$ permit discharge limits for copper. An investigation was immediately initiated to discover the source of the copper. The investigation concluded that a blender, used to homogenize the sample, was leaching copper into the sample prior to analysis. Use of the blender was immediately discontinued, and the results of the investigation were reported to the PCSS. Mass balance calculations performed by Specialty Components showed that if the blender had not been used, the wastewater concentration of copper would have been $0.72 \mathrm{mg} / \mathrm{l}$ and thus not a permit violation. The PCSS agreed with this determination and did not issue a notice of violation to the Pinellas Plant.

On May 24, 1994, Specialty Components discovered a small depression in the ground immediately to the west of Building 700 . Excavation of the surrounding soil revealed a leak in an industrial drain line. The drain line was repaired and placed back into service. The PCSS was notified of this occurrence for informational purposes. 


\subsection{Superfund Amendment and Reauthorization Act (SARA) Title III Reporting}

The Pinellas Plant reports annual toxic chemical inventories and release quantities as required by Sections 312 and 313 of the SARA of 1986, Title III. These reports disclose plant chemical inventories, usage rates, and emission quantities and each is provided to local and state emergency planning committees and to local fire authorities. Additionally, MSDSs are submitted to the local emergency planning committee, state emergency response commission, and local fire departments in accordance with Section 311 of SARA. Table 5-4 summarizes the CY1994 SARA 312 report, submitted March 1, 1995.

Table 5-4. Report of Pinellas Plant's Compounds for Calendar Year 1994

\begin{tabular}{|c|c|c|c|c|}
\hline \multirow[b]{2}{*}{ Chemical } & \multirow[b]{2}{*}{$\begin{array}{c}\text { Days } \\
\text { On-Site }\end{array}$} & \multicolumn{3}{|c|}{ Daily Inventory, lbs. } \\
\hline & & Maximum & Average & $\begin{array}{c}\text { EPA } \\
\text { Designation }\end{array}$ \\
\hline Acetic Acid & 365 & 13,665 & 13,578 & HS \\
\hline Ammonia & 365 & 1,074 & 1,055 & EHS \\
\hline Argon & 365 & 133,400 & 112,460 & HS \\
\hline Ethyl Alcohol & 365 & 5,702 & 2,019 & HS \\
\hline Hydrochloric Acid & 365 & 15,926 & 11,360 & HS \\
\hline Hydrofluoric Acid & 365 & 954 & 852 & EHS \\
\hline Nitric Acid & 365 & 10,556 & 10,107 & $\overline{\text { EHS }}$ \\
\hline Nitrogen & 365 & 320,000 & 297,280 & HS \\
\hline Sodium Hydroxide & 365 & 49,000 & 27,000 & HS \\
\hline Sulfuric Acid & 365 & 38,590 & 23,000 & EHS \\
\hline Toluene 2,4-Diisocyanate & 365 & 608 & 496 & EHS \\
\hline Trichloroethylene & 365 & 16,345 & 15,784 & HS \\
\hline \multicolumn{5}{|l|}{ HS = Hazardous Substance } \\
\hline Ju Iarar & & & & \\
\hline
\end{tabular}

Section 313:

The plant submits SARA Section 313 Reports, toxic release inventories by July 1 of each year for the previous years' release. The calender year 1994 SARA 313 Report will be available July 1, 1995.

\subsection{Continuous Release Reporting}

There were no releases of hazardous substances or extremely hazardous substances, reportable under CERCLA, at the Pinellas Plant in 1994. 


\subsection{GROUNDWATER PROTECTION PROGRAM}

\subsection{Introduction}

In keeping with Specialty Components commitment to successfully administer an Environmental Management Program at the Pinellas Plant, the Environmental, Safety and Health Division implemented a Groundwater Protection Management Program (GPMP). This program's goals are as follows: to determine baseline conditions of groundwater quality; to comply with and implement applicable regulations, laws, and DOE Orders; to update characterization and define trends in the physical and chemical condition of environmental media; to establish baselines of environmental quality; to detect groundwater pollution or contamination; to monitor potential groundwater contamination; and to apply environmental standards to protect human health and the environment.

The Pinellas Plant developed a GPMP Plan in accordance with the guidance of DOE 5400.1, Chapter III, and plans, permits, and other technical documents such as those associated with compliance with the SDWA, RCRA, HSWA, and CERCLA. This plan is reviewed annually and updated at least every three years. It includes, but is not limited to, characterizing groundwater at the Pinellas Plant; designing, documenting, and implementing a groundwater monitoring program; outlining strategies for managing groundwater protection and remediation; summarizing areas that may be contaminated with hazardous substances; and documenting strategies to address and clean up contaminants.

\section{Background}

Groundwater in the vicinity of the Pinellas Plant is encountered within several feet of land surface. Because of the silty, fine sand present from the surface to depths of approximately 30 feet, movement of groundwater is relatively slow. Lateral movement is less than several feet per year unless it is increased by discharge into surface water or by pumping. Downward movement of groundwater from the surficial aquifer is retarded by a confining unit, the Hawthorn Formation. The Hawthorn is primarily clay and is approximately 65 feet in thickness. This unit isolates the surficial sands from the underlying limestones of the Floridan aquifer.

Monitoring wells are installed in the vicinity of the Pinellas Plant to measure groundwater elevation and water quality at various depths and locations in the surficial sands, the Hawthorn Formation, and the Floridan aquifer. The wells are constructed within strict specifications to enable accurate results for the evaluation of groundwater movement and quality. Monitoring wells are also installed in former waste management areas and surrounding the plant site. Some monitoring wells are present near operating recovery wells and are used to monitor water level data and water quality. Monitoring wells are crucial for tracking the groundwater movement and evaluating the effectiveness of contaminated groundwater removal in the surficial sands. 


\subsection{Description of the Ground water Monitoring Program}

The Groundwater Monitoring Program (GMP) at the plant is one module of the Environmental Monitoring Program (EMP). The GMP is administered by Specialty Components Environmental, Safety and Health personnel, who coordinate and maintain third-party subcontractors to provide field and laboratory services. Subcontractors are required to follow EPA- and FDEP-approved sampling and analytical methodology. Groundwater sampling and analyses are either in response to a specific request for analysis, or as part of the on-going, routine quarterly sampling program.

Groundwater sampling is in accordance with a schedule that is reviewed annually and is subject to revision based on changes in regulatory requirements and reported groundwater quality data. The schedule includes the monitoring wells that are sampled, the frequency of sampling, and the contaminants that are analyzed. Pinellas Plant groundwater quality data are compared to drinking water standards that are set by the EPA and the FDEP. The more stringent of the two standards is used for comparison. Standards serve as a convenient reference, and if proposed standards exist for a contaminant, they may also be used as a reference.

Sampling methods, laboratory procedures, and the placement of monitoring wells and well screens all affect monitoring results, and the accuracy of instruments used to measure water quality may also vary. When results are lower than these levels, a laboratory may report them as BDL, or the result is indicated by a less than sign (e.g., <0.05). Based on these factors, a single reported value above a drinking water standard may be anomalous; therefore, it is important to look for patterns or trends in data. An anomaly may also result outside an observed trend, and if one occurs at a well, the well is resampled for verification.

Table 6-1 identifies the sampling episode, the parameters sampled, and the number of samples collected. All subcontracted laboratories performing analyses are certified by the HRS and the FDEP. Analytical results are submitted to Specialty Components Environmental, Safety and Health personnel in both hard copy and electronic form. The draft data are compiled in a data base which is reviewed against historic data to evaluate trends in groundwater quality. The data base is used to organize and review data for analysis, reference, and documentation. Results are screened for manual errors with corrections made only with subcontractor concurrence, if applicable. 
Table 6-1. Pinellas Plant Groundwater Monitoring Program

\begin{tabular}{|c|c|c|c|}
\hline Sampling Episode & VOCs & Metals & Tritium \\
\hline January & 128 & 125 & 205 \\
\hline April & 135 & 3 & 47 \\
\hline July & 132 & 132 & 132 \\
\hline October & 100 & 100 & 43 \\
\hline
\end{tabular}

Once the screen and review cycle is complete, the draft report is finalized into a quarterly report that is submitted to DOE/PAO. The reports detail chemical trends in the monitoring wells, recovery well influent to the treatment system, and other pertinent data.

After remedial assessment and investigation, monitoring is discontinued at areas that pose no potential threat to the environment or public health and require no further action. An evaluation occurs before the subsequent annual sampling program to determine the areas that will be retained for further monitoring. Groundwater monitoring at the perimeter boundary of the Pinellas Plant and the Floridan aquifer continue to demonstrate environmental compliance and protection.

\subsection{Hydrogeology}

The groundwater system underlying the Pinellas Plant has three primary water bearing units, as depicted in Figure 6-1. The upper saturated unit, the surficial aquifer, is associated with the upper 30 to 40 feet of undifferentiated sands. The surficial aquifer extends from approximately 5 feet below land surface to the top of the Hawthorn Formation, approximately 30 to 40 feet below land surface. The surficial deposits are primarily sand and shelly sand that grade into marl and sandy clay with increased depth. Groundwater in the surficial aquifer is unconfined; however, clay and/or silt layers and sand lenses exist within the surficial aquifer in the vicinity of the plant. Thus, hydraulic properties of the surficial aquifer can vary widely due to variations in the types and physical properties of material in the aquifer. Data generated as part of environmental restoration activities indicate approximate ranges. Some site specific hydraulic and geotechnical properties at the plant range as follows:

$\begin{array}{ll}\text { Transmissivity } & 9-30 \mathrm{ft}^{2} / \text { day } \\ \text { Horizontal Hydraulic Conductivity } & <1-4 \mathrm{ft} / \mathrm{day} \\ \text { (Surficial Aquifer) } & \\ \begin{array}{l}\text { Vertical Hydraulic Conductivity } \\ \text { (Hawthorn) }\end{array} & 0.001-0.00007 \mathrm{ft} / \mathrm{day} \\ \begin{array}{l}\text { Storage Coefficient } \\ \text { (Surficial Aquifer) }\end{array} & <0.05-0.01 \\ \text { Percent Sand } & 23-78 \% \\ \text { Percent Silt } & 11-28 \%\end{array}$




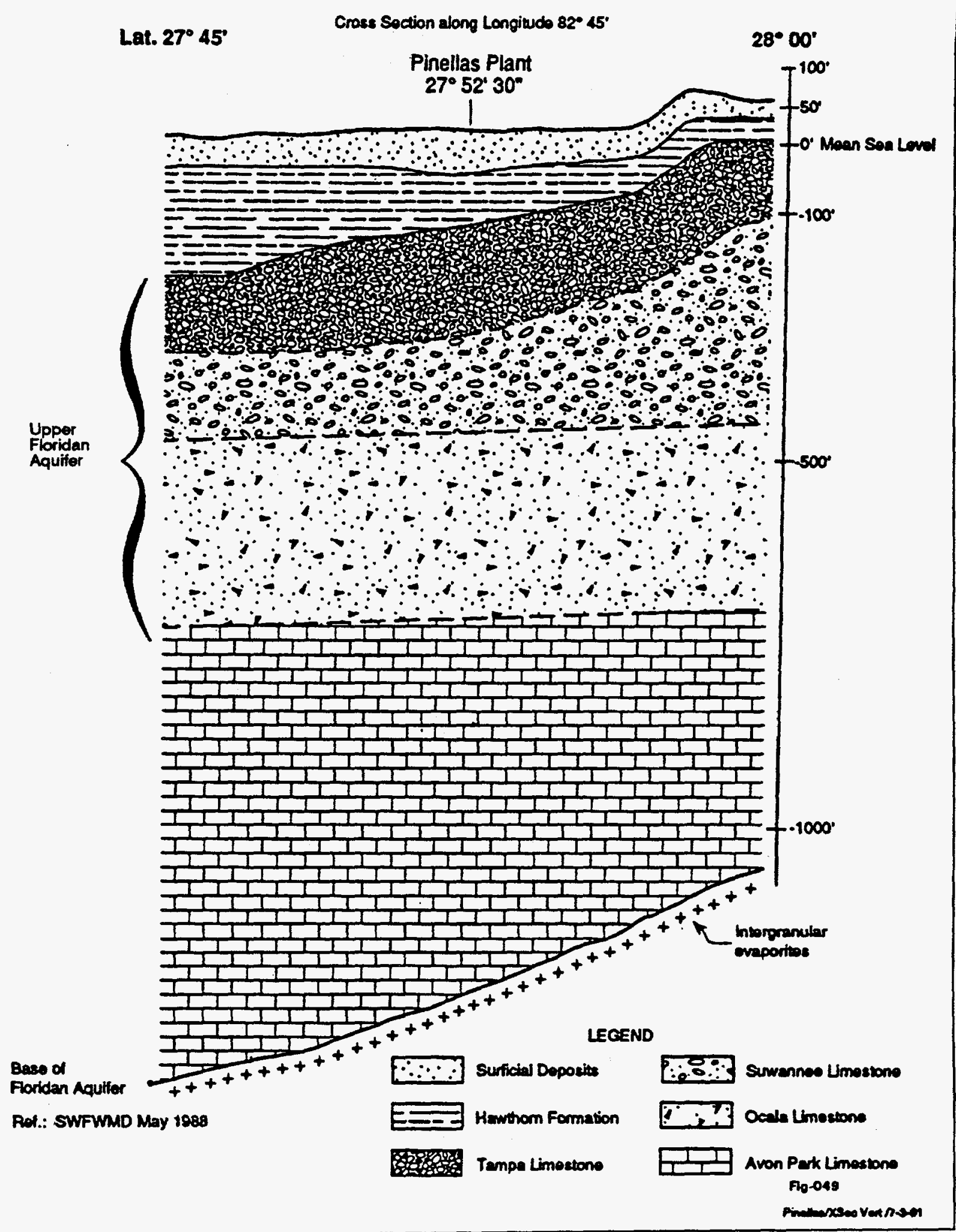

Figure 6-1. Generalized Geologic Cross-Section in the Vicinity of the Pinellas Plant 
The potentiometric or groundwater surface of the surficial aquifer fluctuates approximately 1 to 4 feet seasonally. As shown in Figures 6-2 through 6-5, groundwater flow patterns across the plant remain relatively consistent throughout the year. Groundwater flow in the surficial aquifer is toward the northwest and southeast, away from a groundwater high that trends across the site from the northeast to the southwest. The East and West Ponds intercept the water table, but do not act as significant groundwater recharge bodies or discharge points. The West Pond receives no runoff, and a spillway controls levels in the East Pond.

Clays, fine-grained sandstone, and weathered limestone of the Hawthorn Formation underlie the surficial aquifer. Borehole logs of three Floridan monitoring wells on the plant property indicate the Hawthorn Formation is approximately 65 to 75 feet thick below the plant. The Hawthorn Formation is continuous across the plant property. Laboratory measurements of permeability samples collected from the Hawthorn Formation characterize it as an aquitard.

The major unit underlying the Hawthorn Formation is the Floridan aquifer. The Floridan aquifer is economically important because it is a municipal water supply source in northern Pinellas County. It is also a reservoir for the injection of reclaimed water and for small quantity domestic use (i.e., irrigation) in the county's central and southern portions. The Floridan aquifer's groundwater becomes highly mineralized near the coast and with increasing depth. The top of the Floridan aquifer occurs at approximately 100 feet below land surface at the Pinellas Plant. Deeper portions of this aquifer and regional groundwater flow, northeast toward Tampa Bay, are shown in Figure 6-6.

\subsection{Description and Groundwater Results of Areas of Potential Environmental Concern}

The Pinellas Plant GMP includes approximately 185 wells. Monitoring wells at the plant are screened in the surficial aquifer. Approximately 120 wells are used for water quality sampling. Except for three, all the wells sampled are screened within the surficial aquifer. Twenty-four wells are used to evaluate groundwater quality at the plant boundary. Three monitor the Floridan aquifer, 27 monitor groundwater quality on an adjacent parcel of property (4.5 Acre Site), and the remaining monitor areas of potential environmental concern. These areas of concern include those identified by the EPA as SWMUs. Section 6.4 .5 references and describes these areas in detail. 


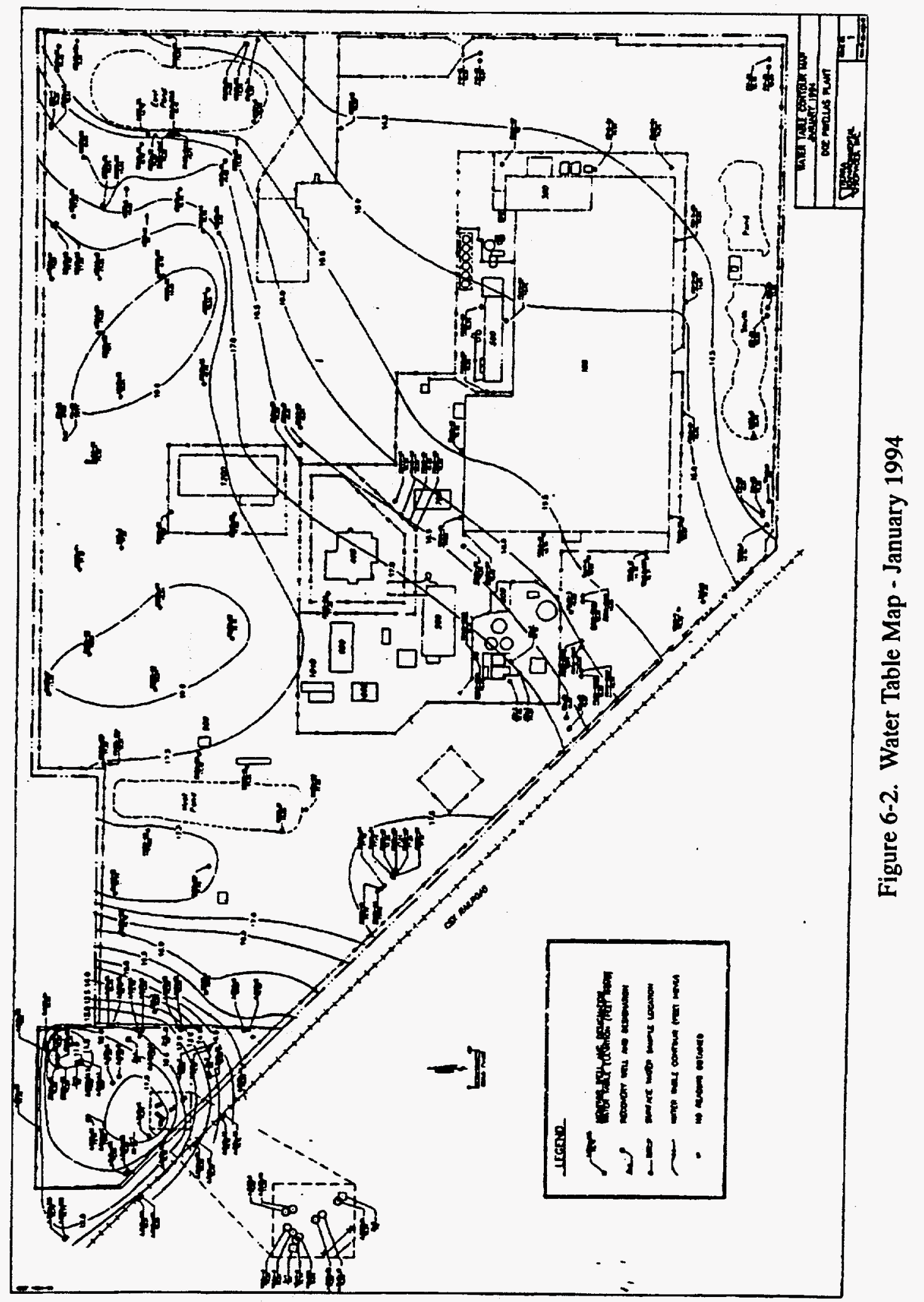




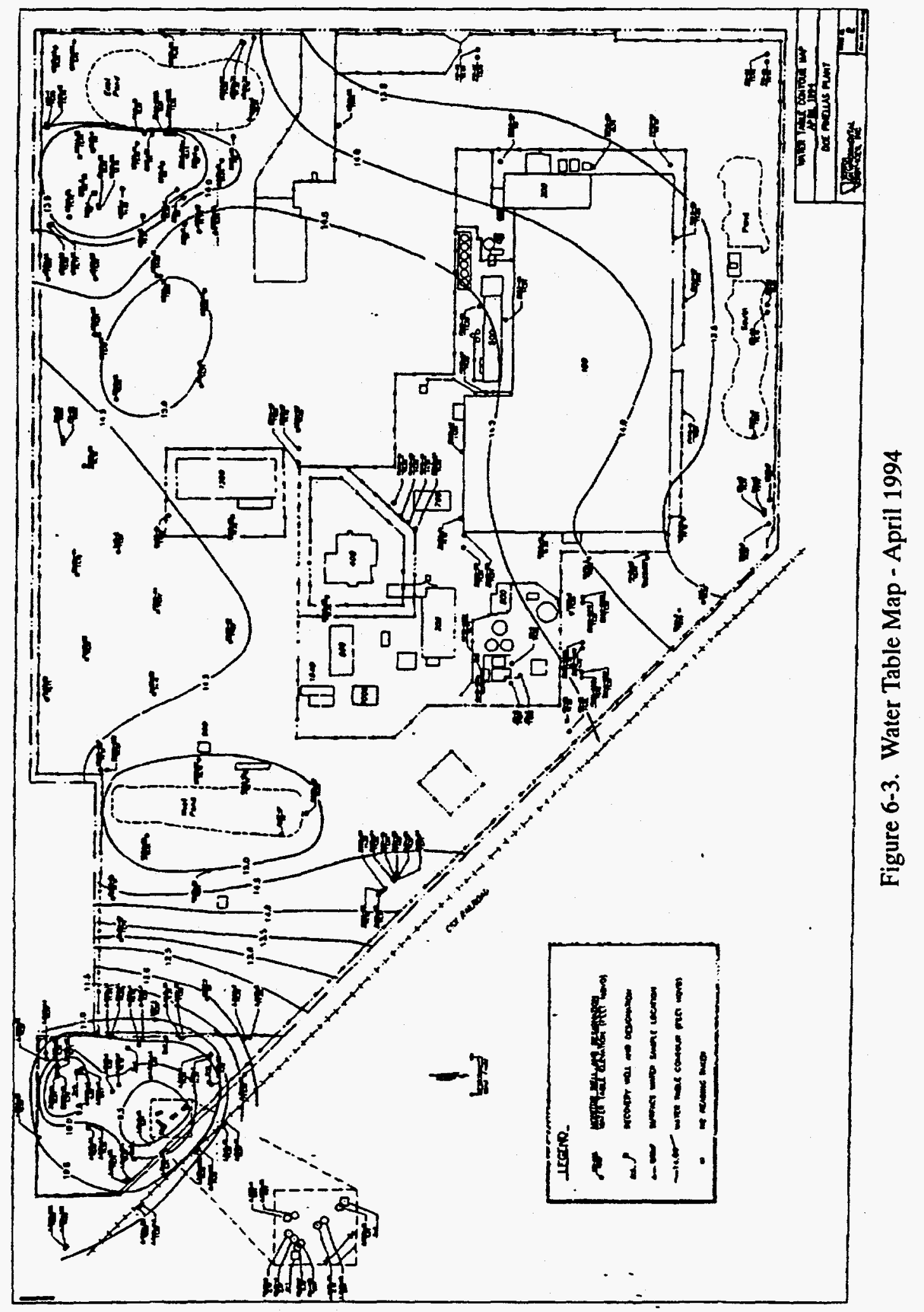




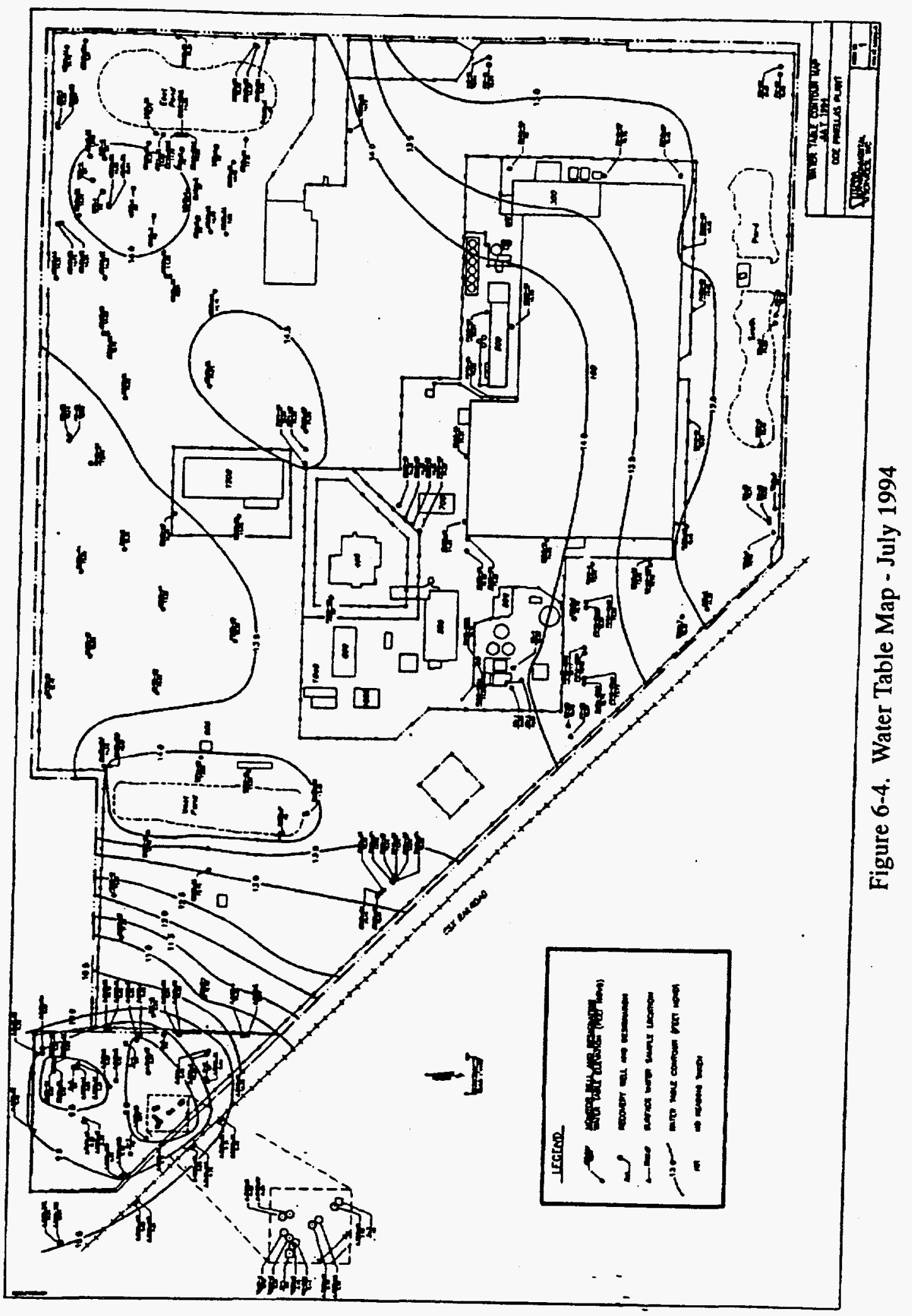




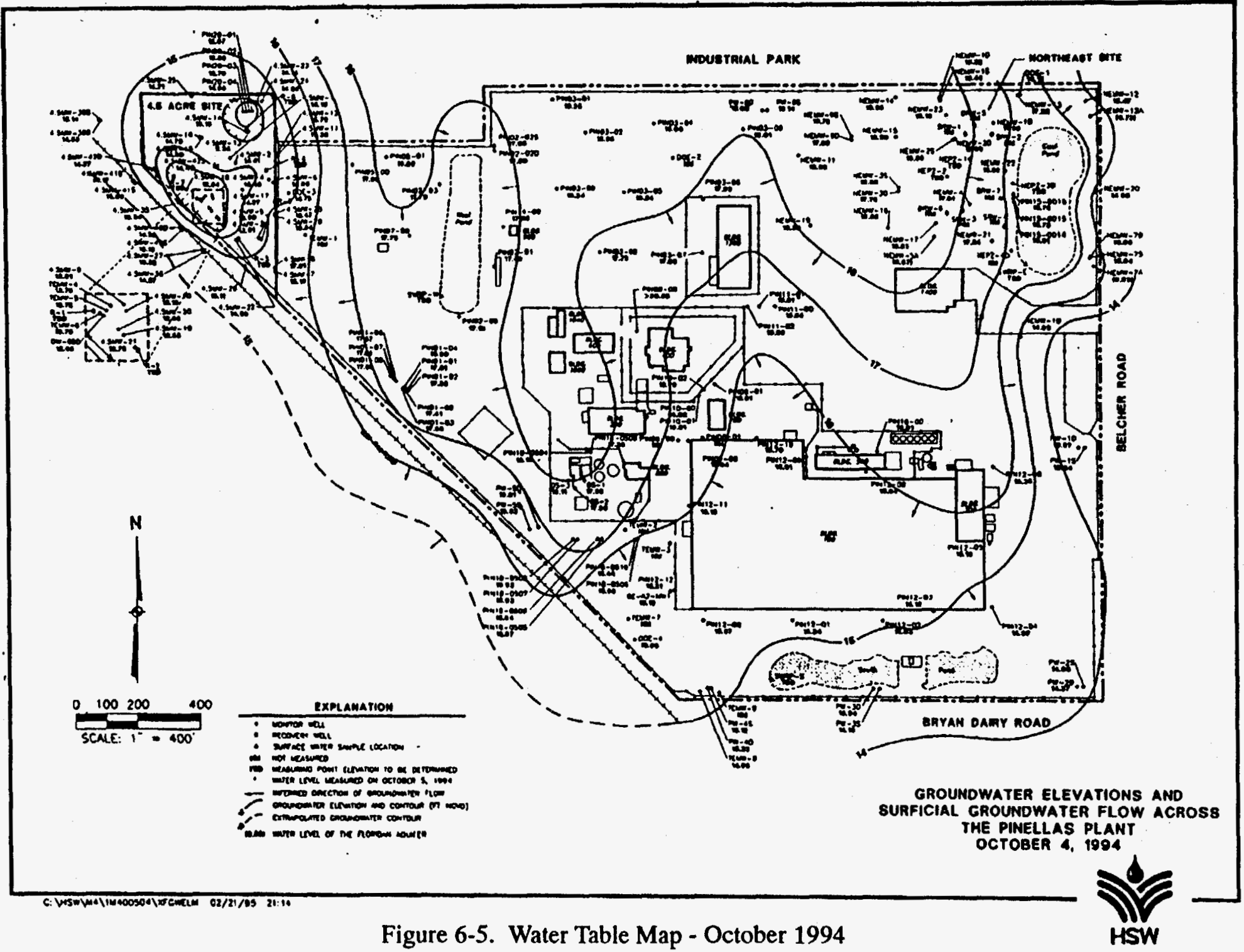




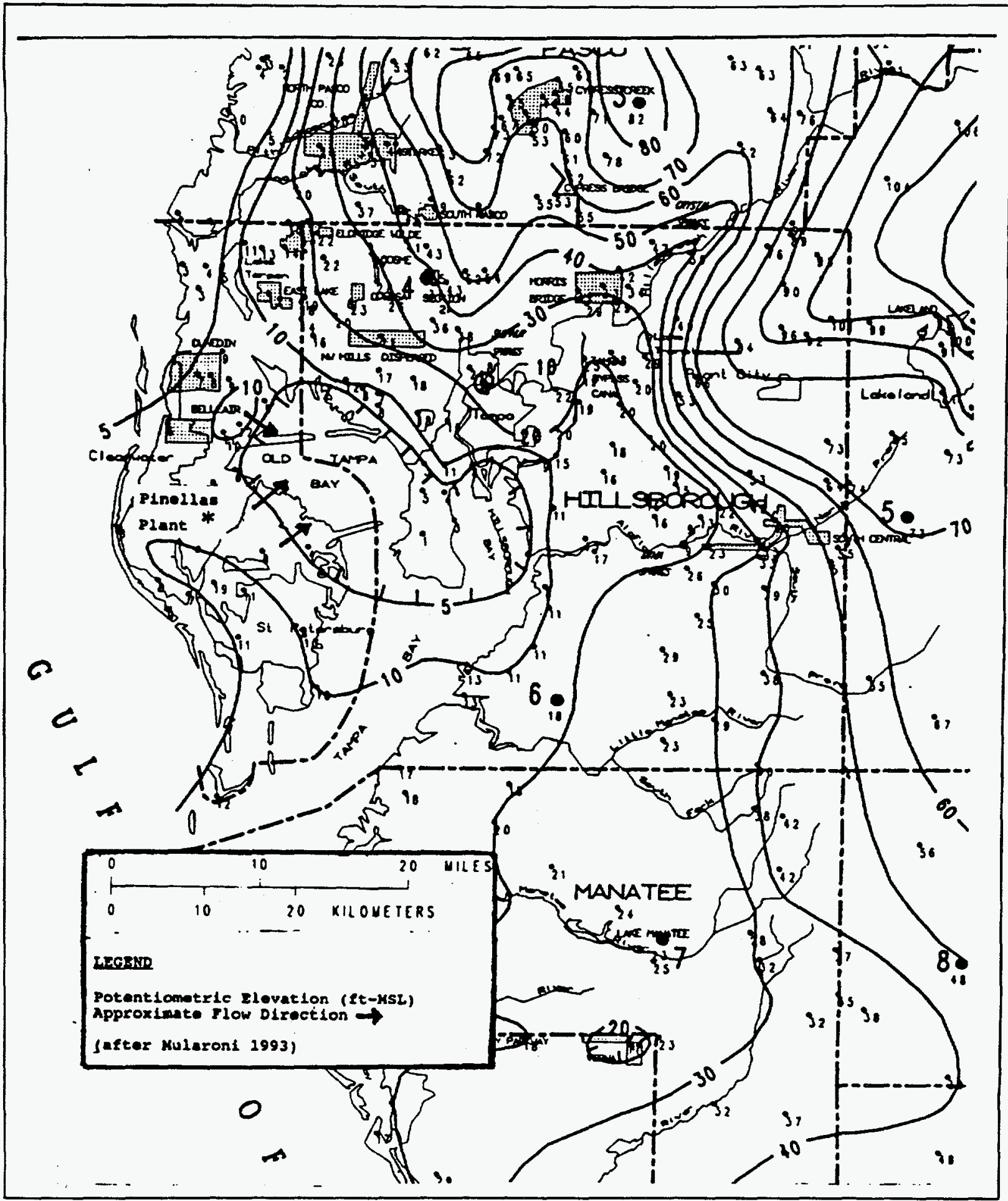

Figure 6-6. Potentiometric Surface of the Upper Floridan Aquifer, September 1992 
This section summarizes data generated by the GMP and the findings and conclusions associated with the Environmental Restoration (ER) Program. Tables 6-2 through 6-4 present a summary of the analytical results from the samples that were collected.

Table 6-2. Tritium Groundwater Sample Concentrations (pCi/l), 1994

\begin{tabular}{|l|c|c|c|c|}
\hline \multirow{2}{*}{ Parameter } & January & April & July & October \\
\cline { 2 - 5 } & Min./Max. & Min./Max. & Min./Max. & Min./Max. \\
\hline Tritium (pCi//) & BDL/3.63 & BDL/3.11 & BDL/3.65 & BDL/2.72 \\
\hline $\begin{array}{l}\text { BDL - Below Detection Limit } \\
\text { NOTE - SDWA Maximum Contaminant Level(MCL) }=20 \mathrm{pCi} / 1\end{array}$ \\
\hline
\end{tabular}

Table 6-3. Metal Groundwater Sample Concentrations, $(\mu \mathrm{g} / \mathrm{l}), 1994$

\begin{tabular}{|l|l|l|l|}
\hline Parameter & \multicolumn{1}{|c|}{ Standard* } & \multicolumn{1}{c|}{ MDL $^{* *}$} & Maximum \\
\hline Antimony & 6 & 60 & $<300$ \\
\hline Arsenic & 50 & 5.0 & 65 \\
\hline Beryllium & 4 & 10 & BDL \\
\hline Cadmium & 5 & 5.0 & 8.5 \\
\hline Chromium & 100 & 10 & 170 \\
\hline Iron & 300 & 100 & 820,000 \\
\hline Lead & 15 & 3.0 & 120 \\
\hline Manganese & 50 & 20 & 1,450 \\
\hline Mercury & 2.0 & 0.2 & 0.8 \\
\hline Nickel & 100 & 50 & 91.9 \\
\hline Selenium & 50 & 5.0 & 35.0 \\
\hline Silver & 100 & 10 & 180 \\
\hline * SDWA - Maximum Contaminant Level and/or FDEP \\
Primary Drinking Water Standards $\mu \mathrm{g} /$ \\
Minimum Detection Level (MDL) in $\mu \mathrm{g} / 1$ \\
(P) = indicates a proposed standard \\
BDL= Below Detection Limit
\end{tabular}


Table 6-4. VOC Groundwater Sample Concentrations, $(\mu \mathrm{g} / 1)$

\begin{tabular}{|l|l|l|l|l|l|}
\hline \multicolumn{1}{|c|}{ Parameter } & Standard* & MDL** & \multicolumn{1}{|c|}{$\begin{array}{c}\text { Maximum } \\
1992\end{array}$} & $\begin{array}{c}\text { Maximum } \\
1993\end{array}$ & $\begin{array}{c}\text { Maximum } \\
1994\end{array}$ \\
\hline 1,2-Dichloroethylene & 70 & 1 & 74,000 & 26,000 & 480,000 \\
\hline Benzene & 1.0 & 1 & 4,800 & 100 & 5,400 \\
\hline Dichloromethane & 5 & 3 & $2,700,000$ & $3,200,000$ & $2,000,000$ \\
\hline Toluene & 1,000 & 5,000 & 44,000 & 14,000 & 170,000 \\
\hline Trichloroethene & 3.0 & 1 & 8,900 & 43,000 & 25,000 \\
\hline Vinyl Chloride & 1.0 & 1 & 42,000 & 19,000 & 37,000 \\
\hline * SDWA - Maximum Contaminant Level and/or FDEP & & \\
Primary Drinking Water Standards $\mu \mathrm{g} / 1$ \\
MDL in $\mu \mathrm{g} / \mathrm{l}$
\end{tabular}

\subsubsection{Procedures and Results}

During 1994, plant personnel recorded groundwater elevation in all monitoring wells quarterly. During an 8-hour period every quarter, water levels were measured in all accessible wells and in the three surface water bodies. These measurements were documented in the field. Water table elevations are determined by subtracting the "depth to water" measurement from the top of the monitoring well casing elevation, surface water gauge, or reference elevation (surveyed points). All recorded elevations reference the mean sea level (MSL). The resulting elevations are used to prepare site specific surficial aquifer potentiometric maps (Figures 6-2 through 6-5). During 1994, surficial groundwater elevations ranged from a low of 5.87 feet above MSL during July, to a high of greater than 20.55 feet above MSL in October, compared to 13.0 and 18.0 feet above MSL during 1993. The overall 1994 annual average groundwater elevation for the plant was 13.21 feet above MSL. This elevation was five feet higher than water levels in the on-site Floridan aquifer monitoring wells. Table 6-5 is a summary of groundwater elevation data. 
Table 6-5. Pinellas Plant Groundwater Elevation Data, (ft. above MSL)

\begin{tabular}{|l|l|l|l|}
\hline Month & Min & Max & Direction \\
\hline Surficial Aquifer & & & \\
\hline January & 7.88 & 18.64 & W\&SE \\
\hline April & 5.91 & 15.94 & W\&SE \\
\hline July & 5.87 & 14.92 & W\&SE \\
\hline October & 9.24 & $>20.55$ & W\&SE \\
\hline Floridan Aquifer & & & \\
\hline January & 7.28 & 7.43 & NE \\
\hline April & 6.13 & 6.24 & NE \\
\hline July & 6.81 & 7.02 & NE \\
\hline December & 9.73 & 9.87 & NE \\
\hline
\end{tabular}

During 1994, groundwater field measurements for temperature ranged from 60 to 92 degrees Fahrenheit, with the average being 78 degrees Fahrenheit. Field measurements for $\mathrm{pH}$ ranged from 4.3 to 8.5 , with a 6.6 average. A maximum conductivity field measurement of $13,690 \mu \mathrm{mhos} / \mathrm{cm}$ was observed with a minimum measurement of $5.8 \mu \mathrm{mhos} / \mathrm{cm}$. The highest conductivity in a well at the Northeast Site ranged between 910 and 13,690 $\mu \mathrm{mhos} / \mathrm{cm}$, which are significantly higher values than those seen in other samples collected in contaminated areas.

All samples, except VOCs, were collected through Teflon tubing from monitoring wells purged with a peristaltic pump. A Teflon bailer attached to a disposable drop line was used to collect samples for VOC analysis. Floridan aquifer monitoring wells were sampled with a Teflon bailer and drop line after purging was complete. Once samples were collected, they were placed in the appropriate containers with preservatives, if required, and stored in coolers with ice. Quality control samples, including equipment blanks, duplicates, splits, field blanks, and trip blanks were also collected, as required by the applicable Comprehensive Quality Assurance Plan (ComQAP). Samples were sent to a

HRS/FDEP-approved laboratory for analyses of various metals, VOCs, and phenols. The plant's Environmental Radiochemistry Laboratory analyzes the samples for tritium.

After each sample collection, the equipment used to evacuate and sample the monitoring well is thoroughly cleaned to minimize the potential for cross-contamination. This process is detailed in the quality assurance project and sampling and analysis plans. It consists of deionized water rinses, detergent scrubbing, dilute nitric acid rinses, isopropanol rinses, a final rinse with contaminant-free water, and air drying. 
During 1994, 349 samples were collected from select monitoring wells for tritium analysis. These monitoring wells are strategically located around the perimeter of Building 100 and the plant perimeter, as well as other specific areas being investigated. The highest concentrations of tritium found in the surficial Floridan aquifer were 3.65 and $0.12 \mathrm{pCi} / \mathrm{ml}$, respectively. These concentrations are significantly below the interim drinking water standard of $20 \mathrm{pCi} / \mathrm{ml}$.

Groundwater samples were collected from 127 monitoring wells and analyzed for 13 various trace metal concentrations. These metal analyses were total manganese $(\mathrm{Mn})$, iron ( $\mathrm{Fe})$, antimony $(\mathrm{Sb})$, lead $(\mathrm{Pb})$, selenium (Se), nickel $(\mathrm{Ni})$, arsenic (As), cadmium (Cd), chromium $(\mathrm{Cr})$, silver $(\mathrm{Ag})$, mercury $(\mathrm{Hg})$, beryllium $(\mathrm{Be})$ and thallium (Th).

The plant found trace metals at levels which exceed EPA or FDEP drinking water standards as follows: manganese, iron, lead, chromium, arsenic, cadmium, and silver. At many locations, elevated concentrations of manganese and iron are attributed to natural conditions of the surficial aquifer. The presence of buried reinforcing bar and other metal may contribute to results reported at some locations. Areas associated with these wells are being investigated under the plant's ER Program (Sections 6.4.4 through 6.4.5).

In 1991, 126 samples were analyzed for PCBs, Polycyclic Aromatic Hydrocarbons (PAH) and/or pesticides. Because the results were either BDL, below regulatory levels of concern, or not identified as contaminants of concern by the ER Program, groundwater analyses of these parameters were discontinued in 1992.

In 1993, no compounds in the phenol analytical group were detected in the 144 samples collected and analyzed. Based on the absence of phenol in the samples collected, phenol analyses were curtailed in 1994.

The VOC concentrations in groundwater represent the primary environmental contaminants at the Pinellas Plant. Of the constituents measured by each analysis, ten were detected in the samples. Table 6-6 is a summary of the results of these analyses and shows an annual decline in concentrations of compounds.

Table 6-6. 4.5 Acre Site Historic High versus Current High, $(\mu \mathrm{g} / \mathrm{l})$

\begin{tabular}{|l|l|l|l|}
\hline $\begin{array}{l}\text { Volatile Organic } \\
\text { Compound }\end{array}$ & $\begin{array}{l}\text { Historic High } \\
\text { Concentration }\end{array}$ & $\begin{array}{l}\text { Current High } \\
\text { Concentration }\end{array}$ & $\begin{array}{l}\text { Percent } \\
\text { Reduction }\end{array}$ \\
\hline 1,1-Dichloroethane & 43 & BDL & $>99 \%$ \\
\hline 1,2-Dichloroethylene & 74,000 & 19,000 & $46 \%$ \\
\hline Trichloroethene & 320,000 & 4 & $>99 \%$ \\
\hline Tetrachloroethane & 880 & BDL & $>99 \%$ \\
\hline Dichloromethane & 680,000 & 2,700 & $99 \%$ \\
\hline
\end{tabular}




\begin{tabular}{|c|c|c|c|}
\hline Volatile Organic & Historic High & Current High & Percent \\
\hline Compound & Concentration & Concentration & Reduction \\
\hline Vinyl Chloride & 79,000 & 20,000 & $75 \%$ \\
\hline Toluene & 44,000 & 14,000 & $68 \%$ \\
\hline Ethyl Benzene & 15 & $\mathrm{BDL}$ & $>99 \%$ \\
\hline Xylene & 5,200 & 4,000 & $23 \%$ \\
\hline
\end{tabular}

The above compounds included cis and trans 1,2-dichloroethylene (1,2-DCE), trichloroethene (TCE), dichloromethane, vinyl chloride (a degradation product), benzene and toluene. These compounds were detected above drinking water standards. All areas associated with elevated levels of VOCs are under investigation or corrective action. In addition, the areas with high concentrations (the 4.5 Acre Site and the Northeast Site) have an interim groundwater remedial action underway (Sections 6.4.4 through 6.4.5).

\subsubsection{Floridan Aquifer}

Three monitoring wells on Pinellas Plant property are screened in the upper Floridan aquifer. These wells are located along the property boundary and immediately outside the most contaminated area of the Northeast Site. An impact to the Floridan aquifer by the plant's current or past operations can be detected by monitoring these wells.

In 1994, no compounds were detected at or above any drinking water standards. To date, no contaminants have been detected in the Floridan aquifer monitoring wells with the exception of one sampling episode in 1987 and one in 1993. In both years, trace levels of acetone and methylene chloride, common laboratory solvents, were detected. Verification sampling revealed no detectable concentrations of acetone; therefore, these isolated incidents were attributed to laboratory artifacts.

\subsubsection{Perimeter Surveillance Network}

The perimeter monitoring well network, completed September 1991, Figure 6-7, monitors the surficial aquifer. Twelve well clusters installed around the perimeter of the plant consist of two or more wells at different depths of the aquifer. During 1994, no trace metals, with the exception of manganese, lead, and iron, were detected above drinking water standards. In these wells, the only compound detected above MCLs in the perimeter well network was the VOC, vinyl chloride. Vinyl chloride was detected at trace levels in perimeter monitoring wells $5 S$ and 5D, located on the west property boundary (West Fenceline) just north of the west parking lot. This area was identified as a SWMU and a treatment system is in the construction phase (Section 6.4.5). 


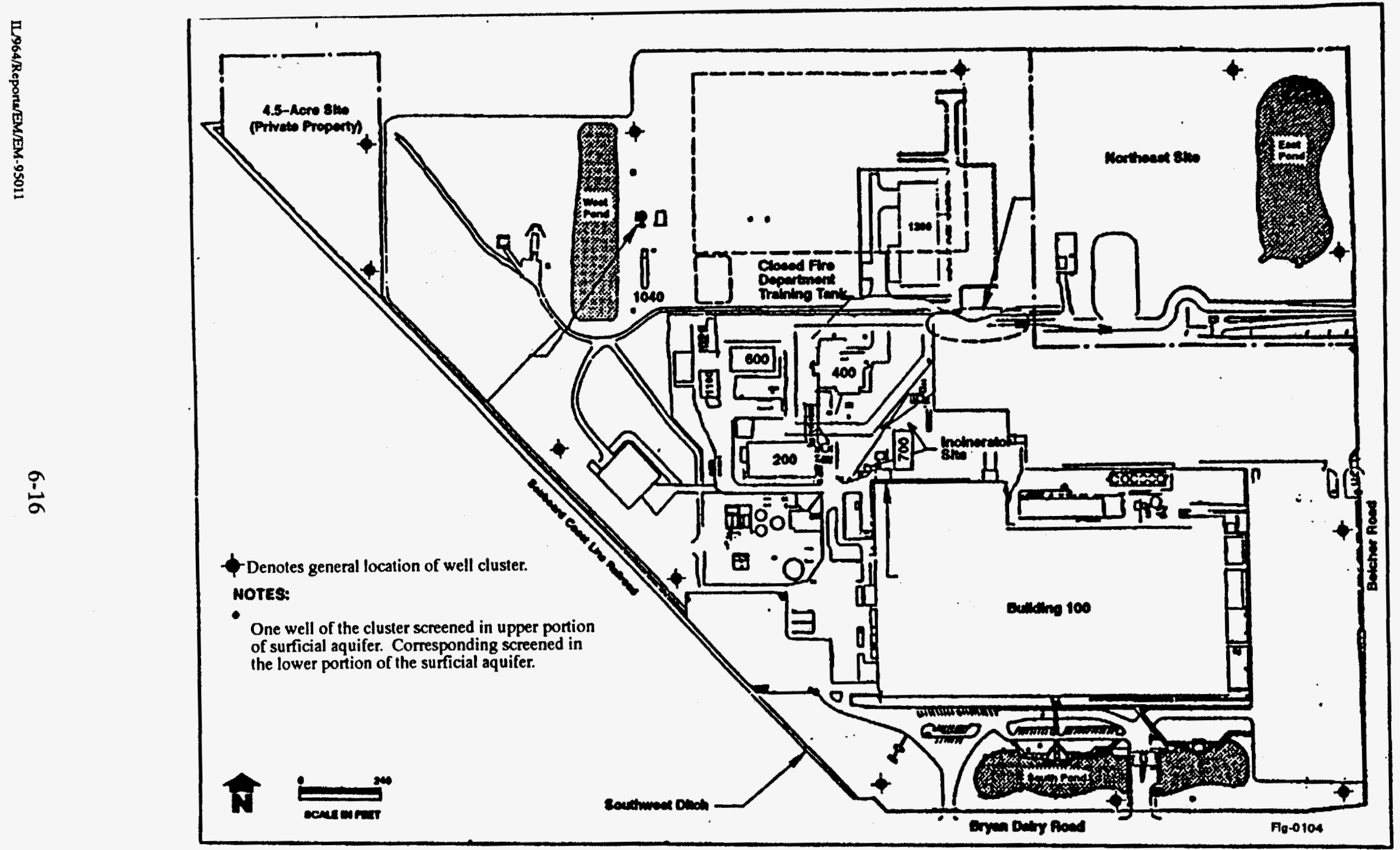

Figure 6-7. Location of Perimeter Groundwater Monitoring Wells 


\subsection{Acre Site}

ER Program activities at the Pinellas Plant were initiated in mid-1984, in response to the DOE Operations Office, Albuquerques' Comprehensive Environmental Assessment and Response Program (CEARP). The program's major emphasis was on past waste management practices that resulted in an adverse environmental impact and whether corrective actions were needed.

The CEARP also assisted DOE in setting environmental priorities and provided justification for funding to carry out remedial actions or enhancements to existing responses if required. This program was initiated to help fulfill DOE's commitment to have all its facilities operate under a policy of full compliance with applicable environmental regulations.

The resin drum disposal area (or the 4.5 Acre Site) is not regulated as a SWMU. This area, however, was identified as the highest priority environmental restoration site. Drums filled with resin and solvent waste from plant operations were disposed of in an area northwest of the present site boundary in the early 1960s, Figure 6-8. Disposal activities consisted of excavation, placement of drums, and back-filling. The land was subsequently sold to a private individual in 1972. Confirmation of these activities occurred in 1985, when the U.S. Geologic Survey was commissioned to perform a surface geophysical survey of this area to ascertain if drums were present. During devegetation activities at the site, the top of one drum was found buried at the immediate surface. The contents were methylene chloride with other trace contaminants. Subsequently, a detailed, voluntary assessment and source removal activity authorized by the FDEP commenced. A total of 83 drums were exhumed, and approximately 300 tons of contaminated waste and soils were disposed of at the Pinewood, South Carolina hazardous waste landfill.

After the source material was removed, the plant conducted a series of studies to identify the areal extent of groundwater contamination resulting from drum leakage. The Pinellas Plant voluntarily followed all FDEP activity and reporting requirements for groundwater cleanup cases. These activities were initiated and/or considered complete upon FDEP written approval, even though no consent order or other formal compliance agreement was issued. The Contamination Assessment Report and Feasibility Study Work Plan were submitted to the FDEP in August 1986 and approved in March 1987. The Feasibility Study Report was submitted and subsequently approved in October 1987. During the feasibility study, an Interim Remedial Action (IRA) was warranted due to the off-site migration of contaminated groundwater. An IRA Plan was submitted and approved in May 1988. The design and construction of the IRA and VOC treatment system was completed May 1990.

The 4.5 Acre Site VOC treatment system was constructed adjacent to the 4.5 Acre Site on Pinellas Plant property. Construction of the system was completed on April 23, 1990. A pre-startup test, conducted May 9, 1990, passed with no 
foreseeable problems. Upon IRA implementation, the Pinellas Plant initiated a monitoring and groundwater sampling and analysis program. The monitoring program consists of groundwater elevation monitoring and benchmark surveying to monitor land surface elevation and potential subsidence along the off-site railroad tracks. The sampling and analysis program incorporates select on-site and off-site monitoring wells and the seven recovery wells. This program

characterizes the contaminant plume configuration and trends in contaminant concentrations.

To date, cleanup goals are consistent with Federal and State standards. A remedial action plan is being prepared that will evaluate, screen, and select a final remedial technology for the site. 


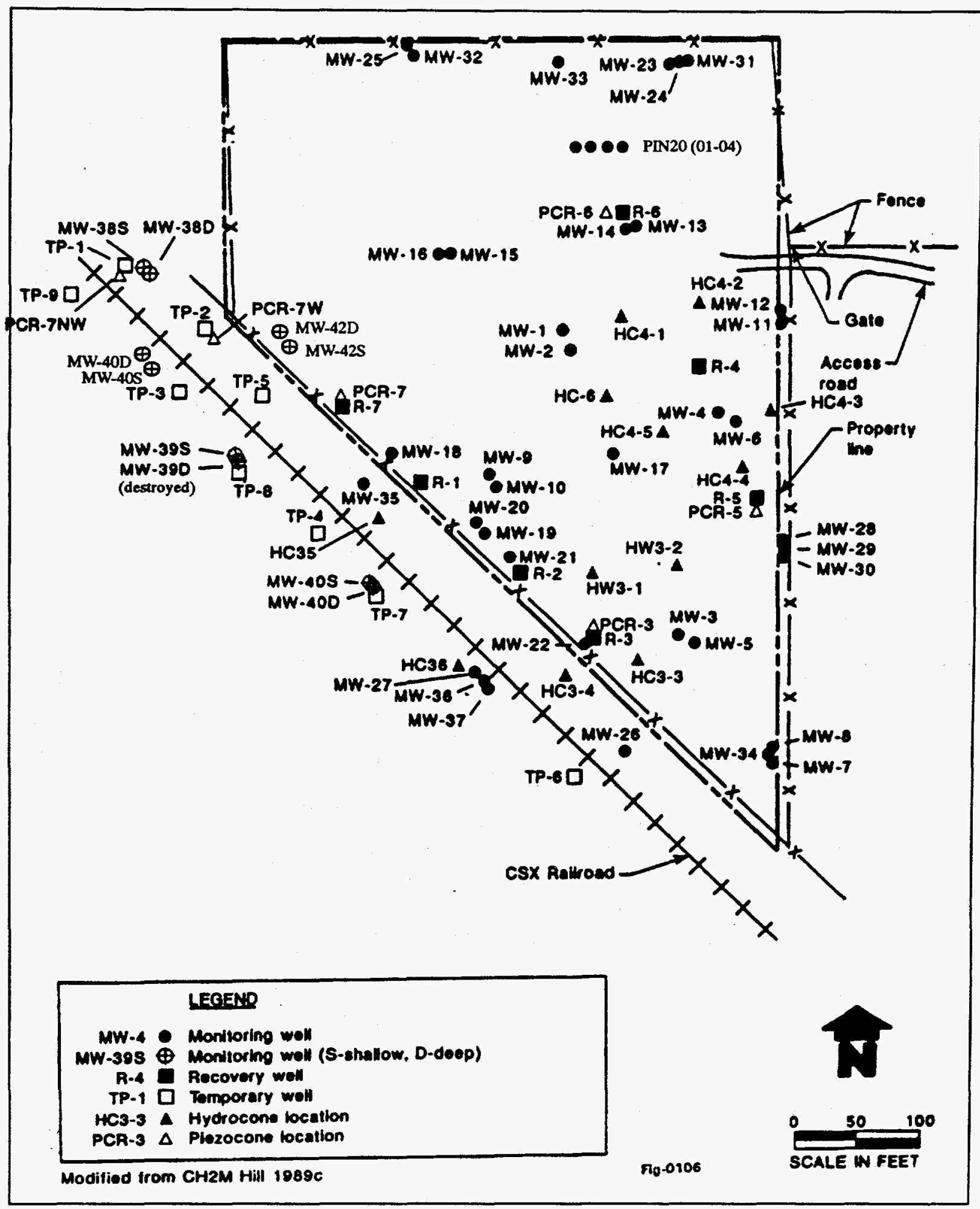

Figure 6-8. Location of Groundwater Monitoring Wells, Piezocone and Hydrocone Sampling 
During 1994, ER activities relating to the 4.5 Acre Site primarily consisted of continued operation and maintenance of the VOC treatment system. A pilot treatment system is currently being evaluated to enhance the effectiveness of groundwater treatment.

As of December 31, 1994, approximately 4.5 years of IRAs were completed. Approximately 9.2 million gallons of groundwater were recovered and treated. Significant levels of contaminants continue to be captured from the recovered groundwater.

During 1994, a total of 274 trace metal samples, 238 tritium samples, and 378 VOC samples were collected from the selected monitoring wells.

The trace metals that exceeded drinking water standards were manganese, arsenic, cadmium, lead, and iron (secondary standard). Lead was detected in a monitoring well at $120 \mu \mathrm{g} / 1$. Iron, commonly found at high concentrations in the surficial aquifer, was reported as high as $820 \mathrm{mg} / \mathrm{l}$ in a recovery well. Manganese was detected at $1,450 \mu \mathrm{g} / \mathrm{l}$, arsenic was detected at $550 \mu \mathrm{g} / 1$, and cadmium was detected at $8.5 \mu \mathrm{g} / \mathrm{l}$. No detectable concentrations of phenol compounds were reported.

The 4.5 Acre Site's recovery system altered the surficial aquifer's hydraulic gradient and flow direction at critical locations. This alteration of the surficial aquifer is a result of the successful extraction of groundwater. Surveying results indicate no subsidence occurred along the railroad tracks of the 4.5 Acre Site.

The Pinellas Plant successfully stabilized the VOC contaminant plume as a direct result of the pump and treat methodology employed at the 4.5 Acre Site. The interim action also reduced the areal extent and magnitude of the total VOC concentrations within the plume. Interim remedial actions will continue until final remedial actions are approved by the FDEP and implemented by the plant. Figures 6-9 through 6-11 show concentrations of total VOCs in wells at the 4.5 Acre Site, which are used to interpret the extent of off-site contamination and as indicators of remediation effectiveness. 


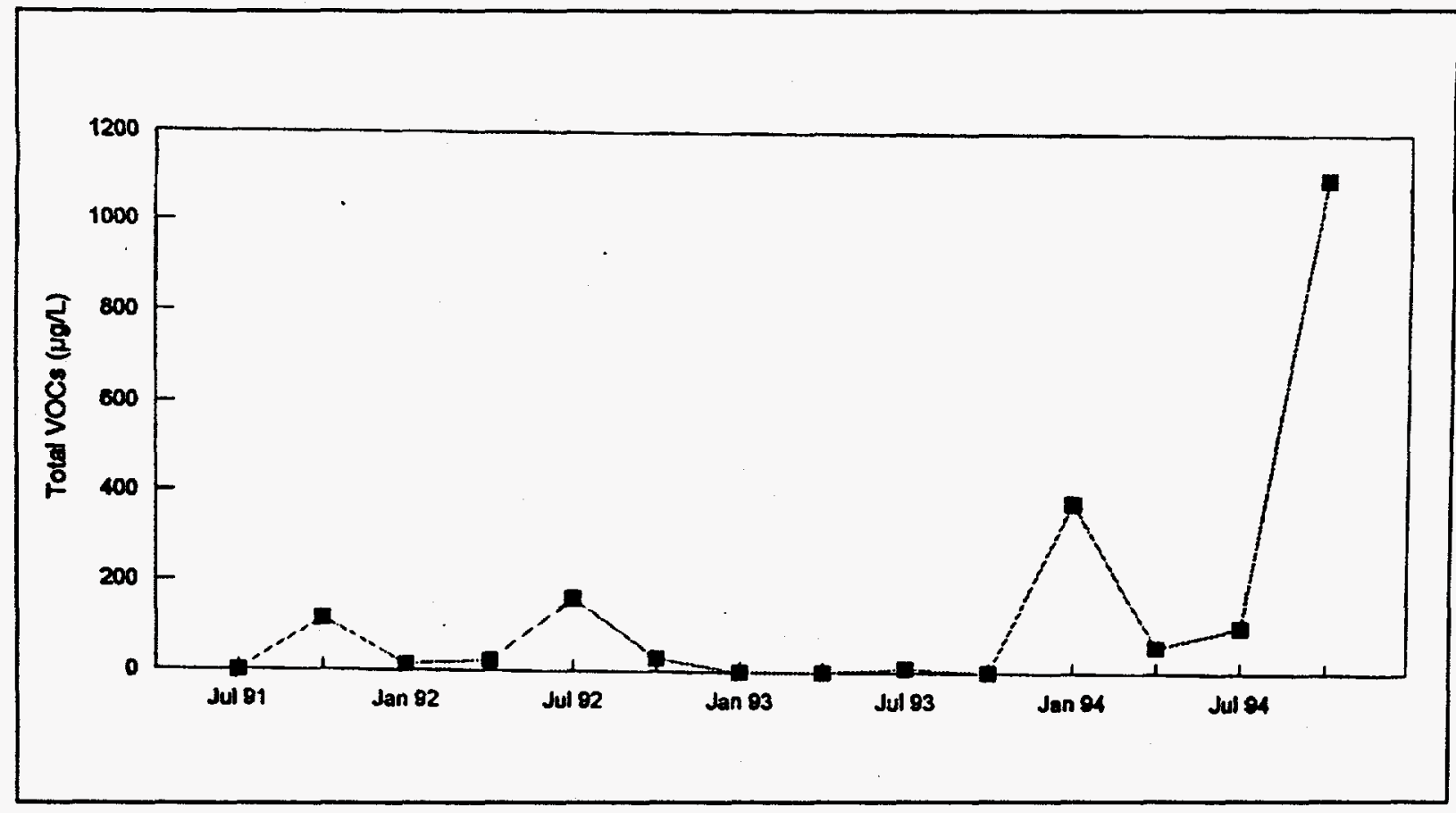

Figure 6-9. Concentration of Total VOCs Recovery Well 4.5 MW-6

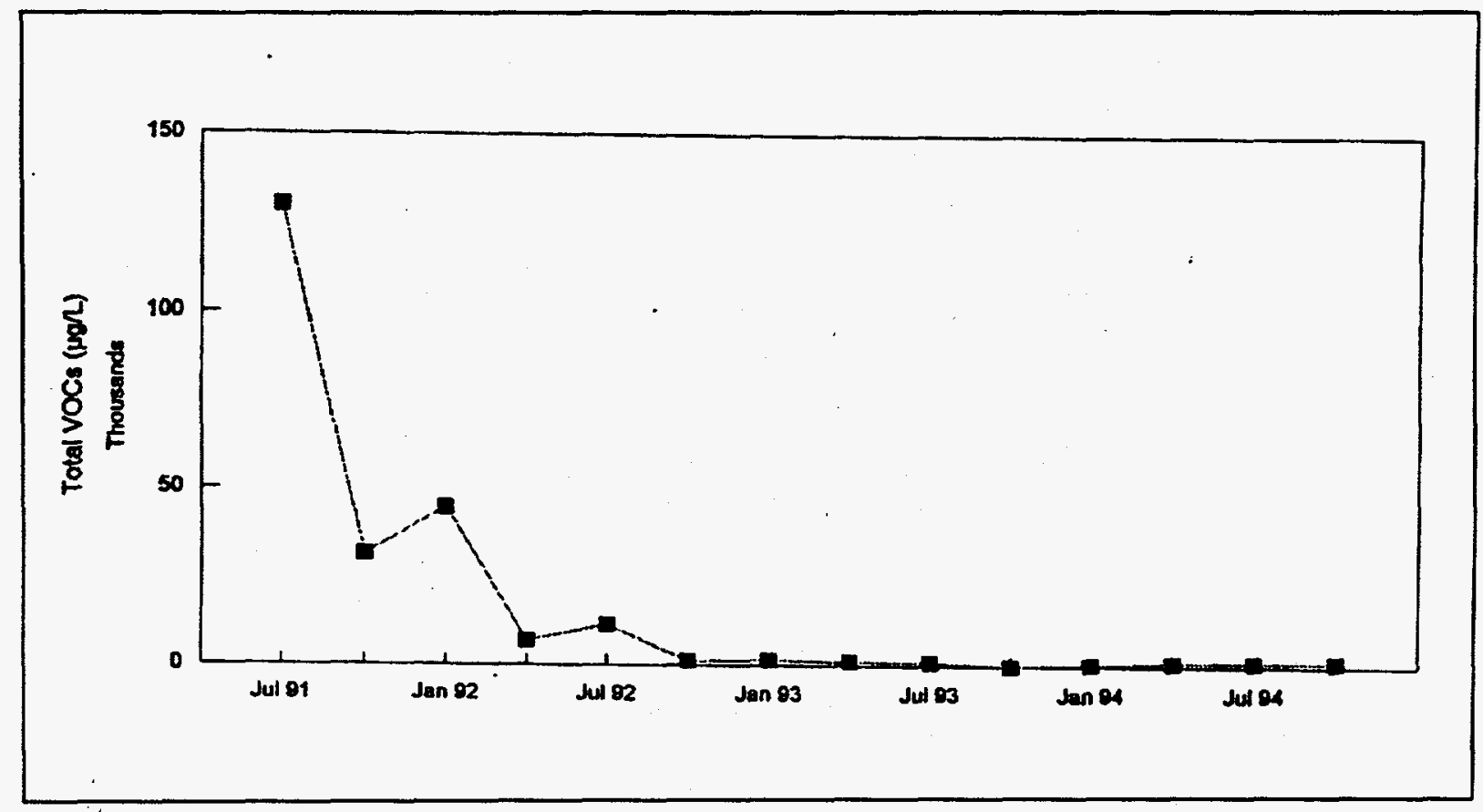

Figure 6-10. Concentration of Total VOCs Recovery Well 4.5 R-3 


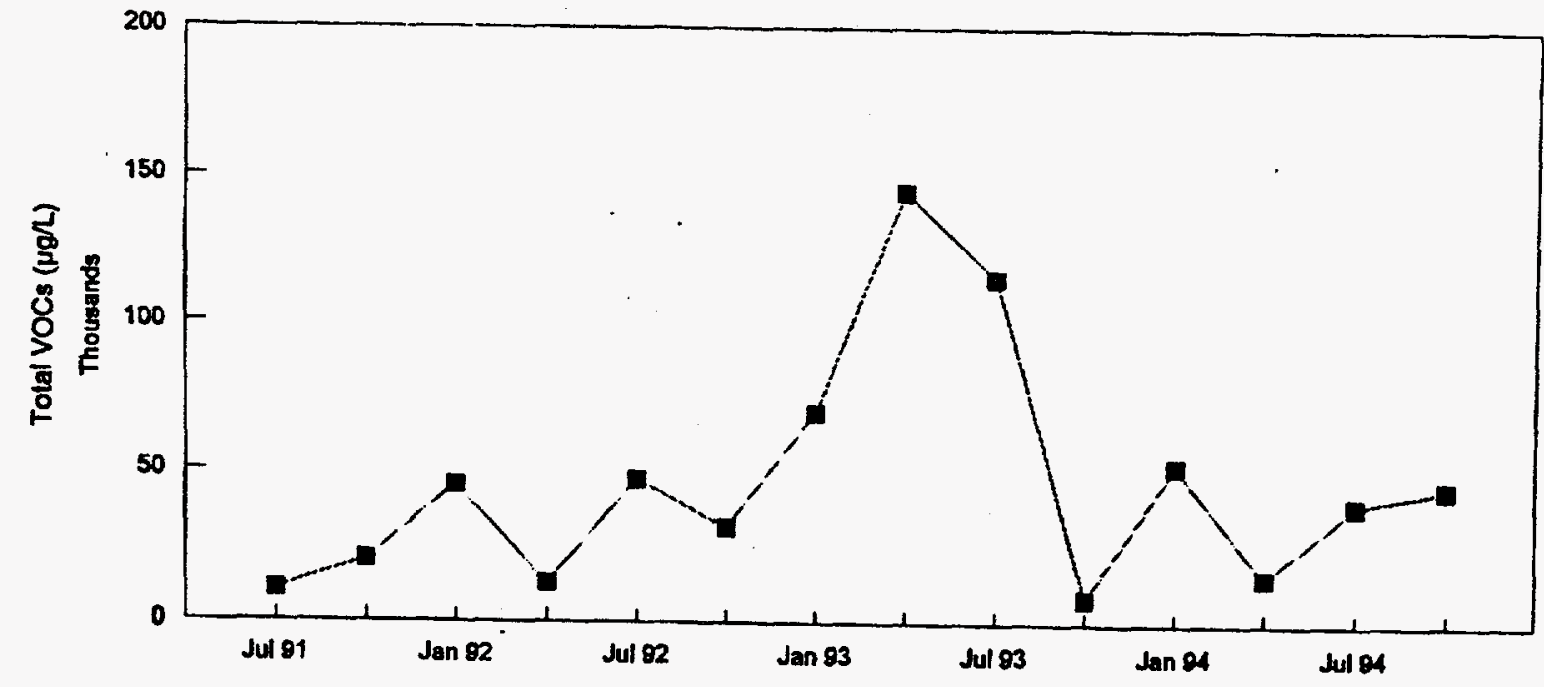

Figure 6-11. Concentration of Total VOCs Recovery Well 4.5 R-4

The air impacts associated with the groundwater treatment facility are minimal and well below state calculated standards. The Maximum Ambient Concentrations (MAC) of the major groundwater contaminants were calculated per FDEP guidance, and the results indicate values well below the FDEP Acceptable Ambient Concentrations (AAC).

\subsubsection{Solid Waste Management Units (or Miscellaneous Sites)}

Through record searches, literature reviews, employee interviews, preliminary assessments, and site inspections, the CEARP identified 14 potential sites for further investigation. Thirteen of the 14 sites, plus some additional areas, are individually identified SWMUs, and either were investigated or are being investigated pursuant to the plant's HSWA Permit. While ER activities were being conducted at the 4.5 Acre Site, other on-site activities were conducted to evaluate these "miscellaneous sites" identified during the CEARP. A majority of this work focused on the Northeast Site, a former waste drum staging area. A Contamination Assessment Report (CAR) was developed and submitted to the FDEP for review and subsequent approval. Approval was granted October 1987. The feasibility study was initiated and completed; however, prior to FDEP submittal, EPA exercised jurisdiction over the miscellaneous sites utilizing its HSWA authority. Prior to EPA issuance of the HSWA Permit, received in February 1990, development of the RFI Work Plan was initiated. This work plan identified all investigatory activities to assess and determine the extent of any environmental impacts associated with current and past waste management 
practices. All known sites of potential environmental concerns were identified in the Pinellas Plant's HSWA Permit as SWMUs. Table 6-7 includes a brief description of each of the SWMUs investigated and Figure 6-12 shows the general location of each of the SWMUs.

Table 6-7. Pinellas Plant SWMUs

\begin{tabular}{|c|c|}
\hline SWMU & Description \\
\hline West Pond (PIN 02)* & $\begin{array}{l}\text { Man-made pond that received pH-neutralized industrial effluent and tertiary } \\
\text { treated sanitary sewage from 1972-1982. }\end{array}$ \\
\hline $\begin{array}{l}\text { Spray Irrigation Site } \\
\text { (PIN 03)* }\end{array}$ & $\begin{array}{l}\text { Land treatment site for pH-neutralized industrial effluent and tertiary treated } \\
\text { sanitary sewage from 1972-1982. }\end{array}$ \\
\hline Trench Site (PIN 05) & $\begin{array}{l}\text { Trenches purported to have received slurry waste from water softeners in the } \\
\text { late } 1950 \text { s. }\end{array}$ \\
\hline $\begin{array}{l}\text { Old Drum Storage } \\
\text { Site (PIN 06) }\end{array}$ & $\begin{array}{l}\text { Site of a storage pad for empty drums formerly containing waste solvents. Pad } \\
\text { was removed in } 1983 .\end{array}$ \\
\hline $\begin{array}{l}\text { Pistol Range } \\
\text { (PIN 07)* }\end{array}$ & Former small-arms firing range for plant guards; removed in 1988. \\
\hline $\begin{array}{l}\text { Closed Fire Dept. } \\
\text { Training Tank } \\
\text { (PIN 08)* }\end{array}$ & Former location of fire training tank used by plant's fire brigade. \\
\hline $\begin{array}{l}\text { Current Fire Dept. } \\
\text { Training Tank } \\
\text { (PIN 14)* }\end{array}$ & Current location of fire training tank used by plant's fire brigade. \\
\hline $\begin{array}{l}\text { Metallic Anomaly } \\
\text { (PIN 04)* }\end{array}$ & $\begin{array}{l}\text { Area associated with a metallic anomaly identified during an electromagnetic } \\
\text { survey performed by the United States Geological Survey (USGS) in } 1985 .\end{array}$ \\
\hline $\begin{array}{l}\text { Incineration Site } \\
\text { (PIN 09)* }\end{array}$ & Locations associated with incinerators formerly located at the Pinellas Plant. \\
\hline $\begin{array}{l}\text { Incineration Ditch } \\
\text { (PIN 10) }\end{array}$ & $\begin{array}{l}\text { Ditch that formerly received incinerator scrubber water and suspected disposal } \\
\text { of small quantities of waste solvents. }\end{array}$ \\
\hline $\begin{array}{l}\text { Diesel Fuel Spill } \\
\text { (PIN 11)* }\end{array}$ & Location of diesel fuel spill that occurred in 1983. \\
\hline $\begin{array}{l}\text { Industrial Drain } \\
\text { Leaks, Bldg. } 100 \\
\text { (PIN 12) }\end{array}$ & $\begin{array}{l}\text { Areas beneath Building } 100 \text {, where potential leaks have occurred from the in- } \\
\text { dustrial and health physics drain system. }\end{array}$ \\
\hline $\begin{array}{l}\text { Southwest Ditch } \\
\text { (PIN 13)* }\end{array}$ & $\begin{array}{l}\text { Location of former industrial and sanitary effluent outfalls from the Pinellas } \\
\text { Plant. The outfalls operated from the beginning of operations at the plant } \\
\text { (1954) until } 1968 \text {. }\end{array}$ \\
\hline $\begin{array}{l}\text { Northeast Site } \\
\text { (PIN 15) }\end{array}$ & $\begin{array}{l}\text { The Northeast Site is associated with the location of a former waste solvent } \\
\text { staging and storage area. The east pond on this site received pH-neutralized } \\
\text { industrial waste and tertiary treated sanitary waste from } 1968 \text { to } 1972 .\end{array}$ \\
\hline
\end{tabular}




\begin{tabular}{|l|l|}
\hline SWMU & Description \\
\hline $\begin{array}{l}\text { Building 500 Spill } \\
\text { Site (PIN 16)* }\end{array}$ & $\begin{array}{l}\text { Located north of Building 500. Former location of an oil drain associated with } \\
\text { compressor blow down. }\end{array}$ \\
\hline $\begin{array}{l}\text { West Fenceline Area } \\
\text { (PIN 17) }\end{array}$ & $\begin{array}{l}\text { An area between the western property boundary and the Wastewater Neutraliza- } \\
\text { tion Area with low levels of VOCs in the groundwater. Source of contamina- } \\
\text { tion is suspected to be a former dumpster area. }\end{array}$ \\
\hline
\end{tabular}




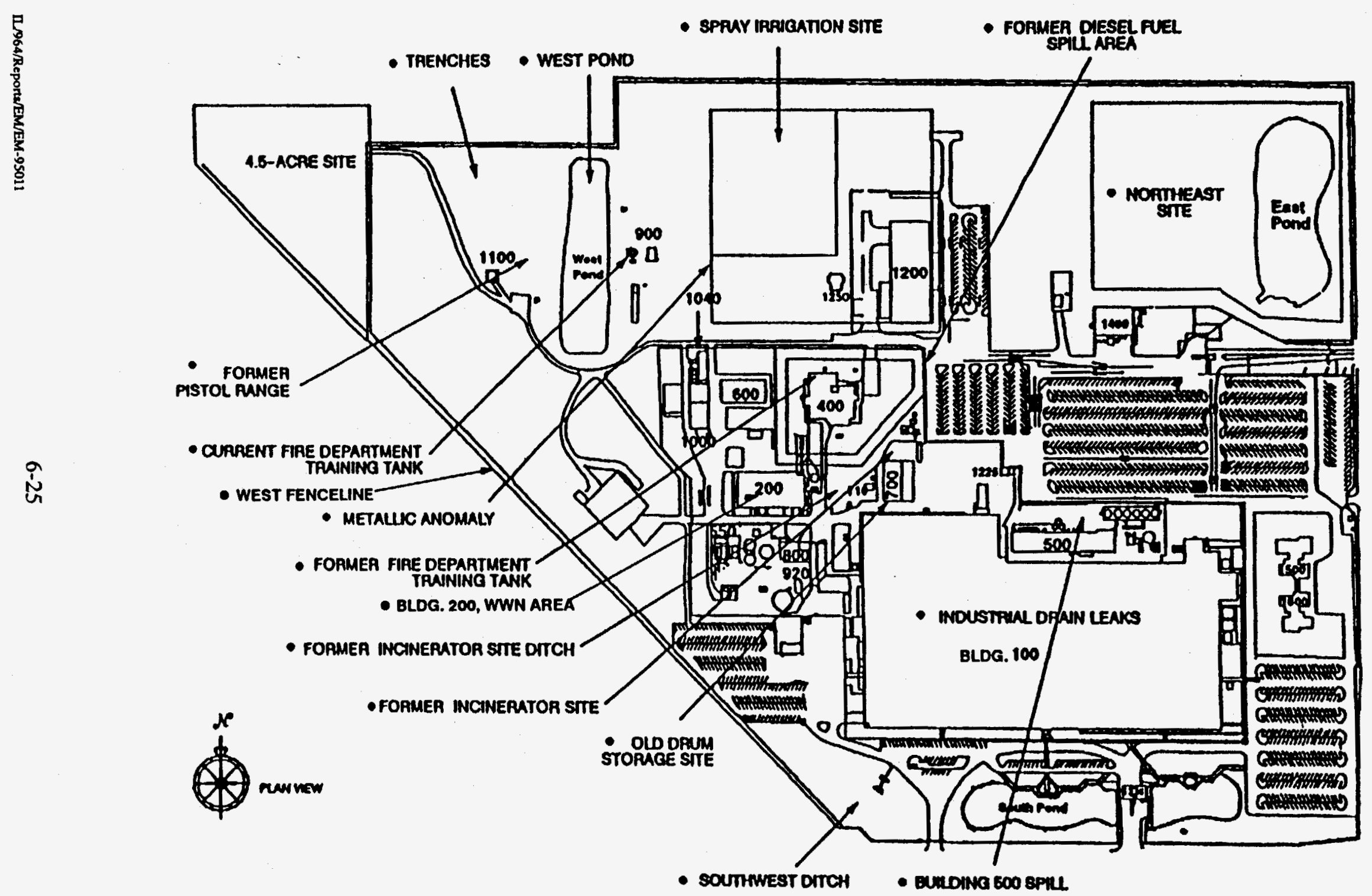

Figure 6-12. Areas of Potential Environmental Concern at the Pinellas Plant 
Figure 6-13 indicates the regulatory steps required to complete remedial action under HSWA. Each "step" includes the following: 1) the development, submittal, and EPA approval of a work plan which delineates the activities to complete, methods of completion, rationale, and justification for the method used; 2) the actual field work, investigation and/or study activities; and 3) the preparation, submittal, and EPA approval of a final report. Under each step in Figure 6-13, are statements relative to the requirements of that step and the current status of the Pinellas Plant as of December 31, 1994.

The ER Program strategy is to initiate and complete as much documentation development and field work as practical, while the regulatory agency is in the process of reviewing the previously submitted document. For example, document development of the Corrective Measures Study Plan (CMSP) was initiated prior to final EPA approval of the RFI report. This strategy is one factor that accounts for the quick progression of the plant's ER Program.

Figure 6-13 depicts the progression of environmental restoration activities associated with the miscellaneous sites. Specifically, the plant completed investigation of the fifteen SWMUs in accordance with the HSWA portion of the plant's RCRA permit. The plant submitted a draft RFI Report to EPA in September 1991, as required. The RFI concluded the plant's current and past operations did not impact the Floridan aquifer and recommended four of the 16 SWMUs (PIN 07, PIN 06, PIN 12, and PIN 15) for a CMS. The RFI identified eleven SWMUs for No Further Action (NFA) based on the results of site characterization. Pursuant to EPA comments, an addendum to this report was submitted in March 1992.

In May 1992, EPA provided the plant with a conditional approval of the RFI Report which included the following: 1) concurrence that the plant did not impact the Floridan aquifer, 2) concurrence with the four SWMUs that require a CMS, 3) identification of the additional monitoring requirements at four SWMUs, and 4) identification of the remaining SWMUs that required no further action. The additional monitoring requirements were completed. ER monitoring activities revealed no contaminants above regulatory standards, and in 1993, a report was submitted to the EPA.

In July 1992, a Corrective Measures Study Plan (CMSP) was submitted to EPA for the four SWMUs requiring a CMS. The plan stated three individual CMSs would be prepared, one for the Former Pistol Range, one for the Northeast Site, and one combining Building 100 and the Old Drum Storage Pad. Industrial Drain Leaks, Building 100, and the Old Drum Storage Pad were combined due to the proximity (co-location) of the sites to each other and the similar contaminant of concern identified during the RFI. EPA comments on the CMSP were received, addressed, and in November 1992, an addendum was submitted to the plan. Work on the Building 100/Old Drum Storage Pad CMS was initiated in late 1992, with regulatory submittal in February 1994. Approval of the Building 100/Old Drum Storage Pad CMS was granted in January 1995, with the CMS recommending installation of two pumping wells and the expansion of the monitoring well network. 


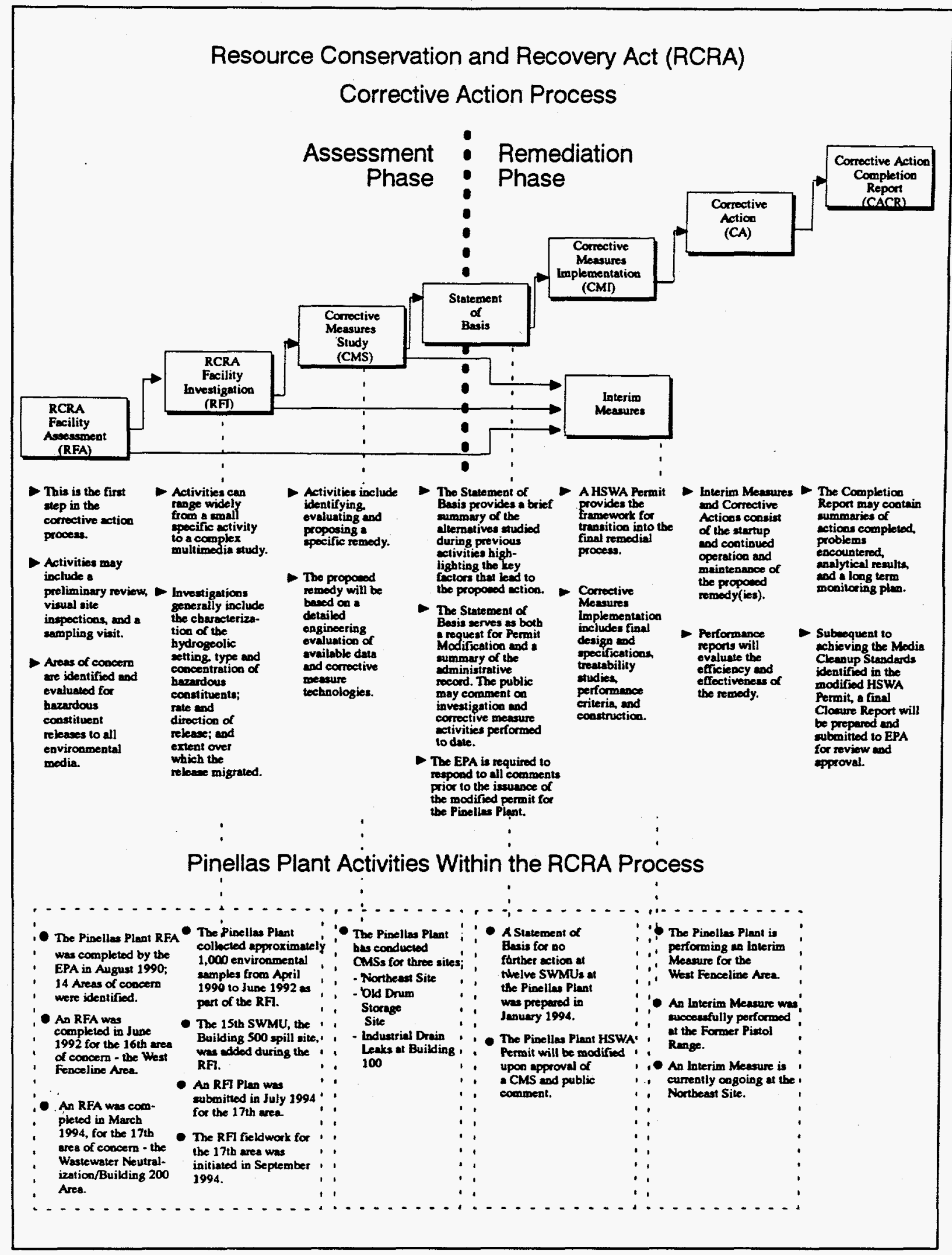

Figure 6-13. Regulatory Steps of Remediation 
During January and February 1993, 473 tons of lead-contaminated soil was excavated from the top foot of the land surface at the Former Pistol Range to reduce the lead in the soil to naturally occurring levels pursuant to an EPA-approved interim corrective measures plan. The soil was subsequently stabilized and disposed of at an EPA-approved hazardous waste facility. The interim measure was completed on March 12, 1993, satisfying the requirements of the Pinellas Plant HSWA Permit. A September 1993 statement of basis summarizing information presented in the RFI and interim measure was submitted to the EPA recommending no further action at the Former Pistol Range and 11 other SWMUs. In addition to this action, the Northeast Site is currently undergoing interim measures in accordance with the permit and under approval of the EPA Regional Administrator. The plant is submitting quarterly performance reports to the EPA, as required. From January to March, 1994 the groundwater extraction system at the Northeast Site was optimized to focus more on the highly contaminated areas. Thus, contaminant recovery significantly increased beginning in April 1994.

In January 1994, additional drums and debris were discovered at the Northeast Site during the installation of recovery well piping. An interim measures addendum was prepared to propose the location and methods for removing the drums and debris at the site. The proposed debris removal activities will be performed in FY95 concurrent with the ongoing interim measures and will be consistent with regulatory requirements and with DOE needs for a feasible and easily implemented action.

Figures 6-14 through 6-16 show concentrations of total VOCs in selected wells at the Northeast Site. Wells NEMW-2S and 4 show a general decline in concentrations to trace levels or below detection limits $(0 \mathrm{ug} / \mathrm{l}$ on graph). Other wells show a variable trend, usually an overall decline. This is evident for well NEMW-3D. Such variation will be addressed in the final corrective measures at this site. 


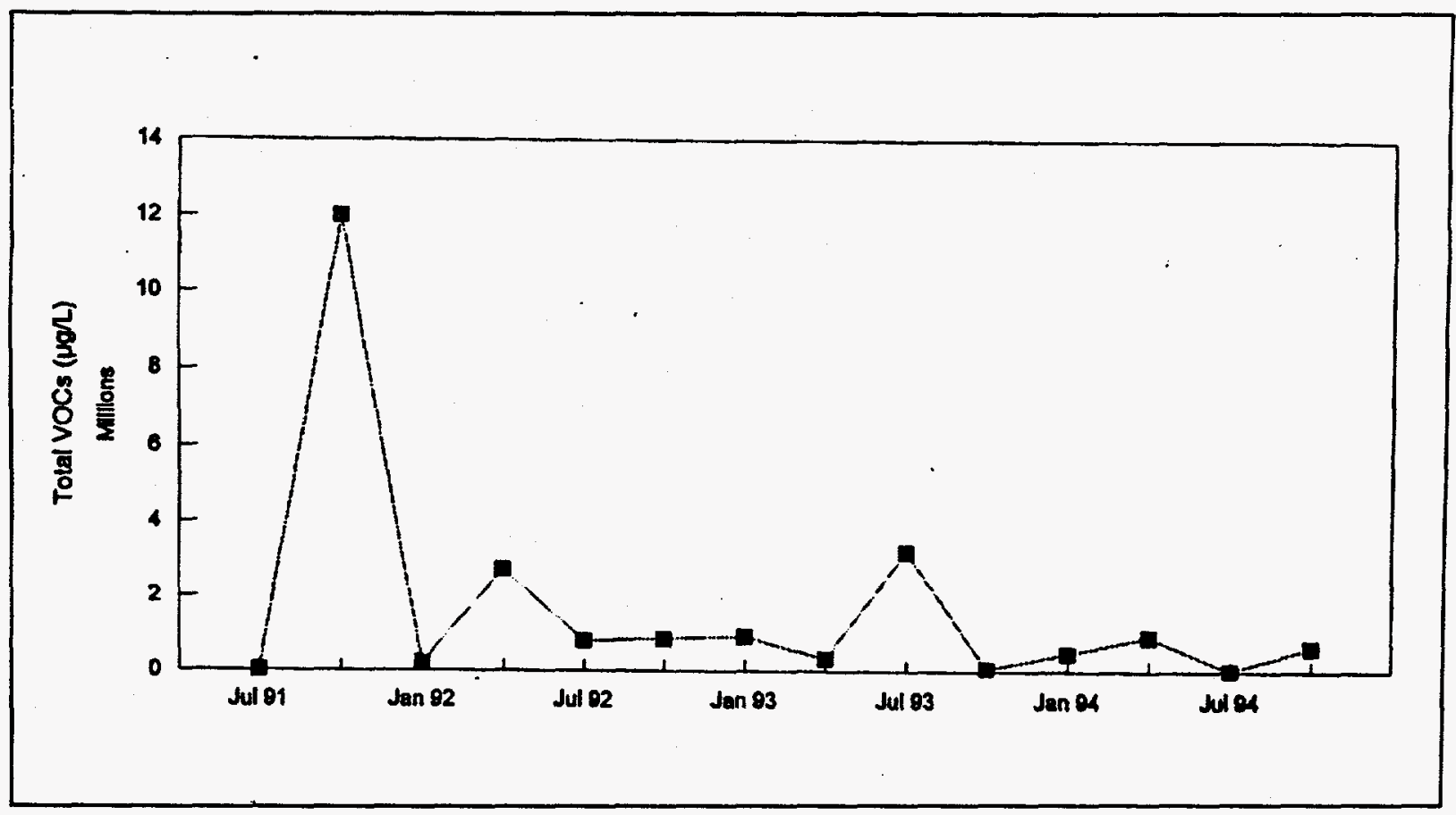

Figure 6-14. Concentration of Total VOCs Monitor Well NEMW-2S

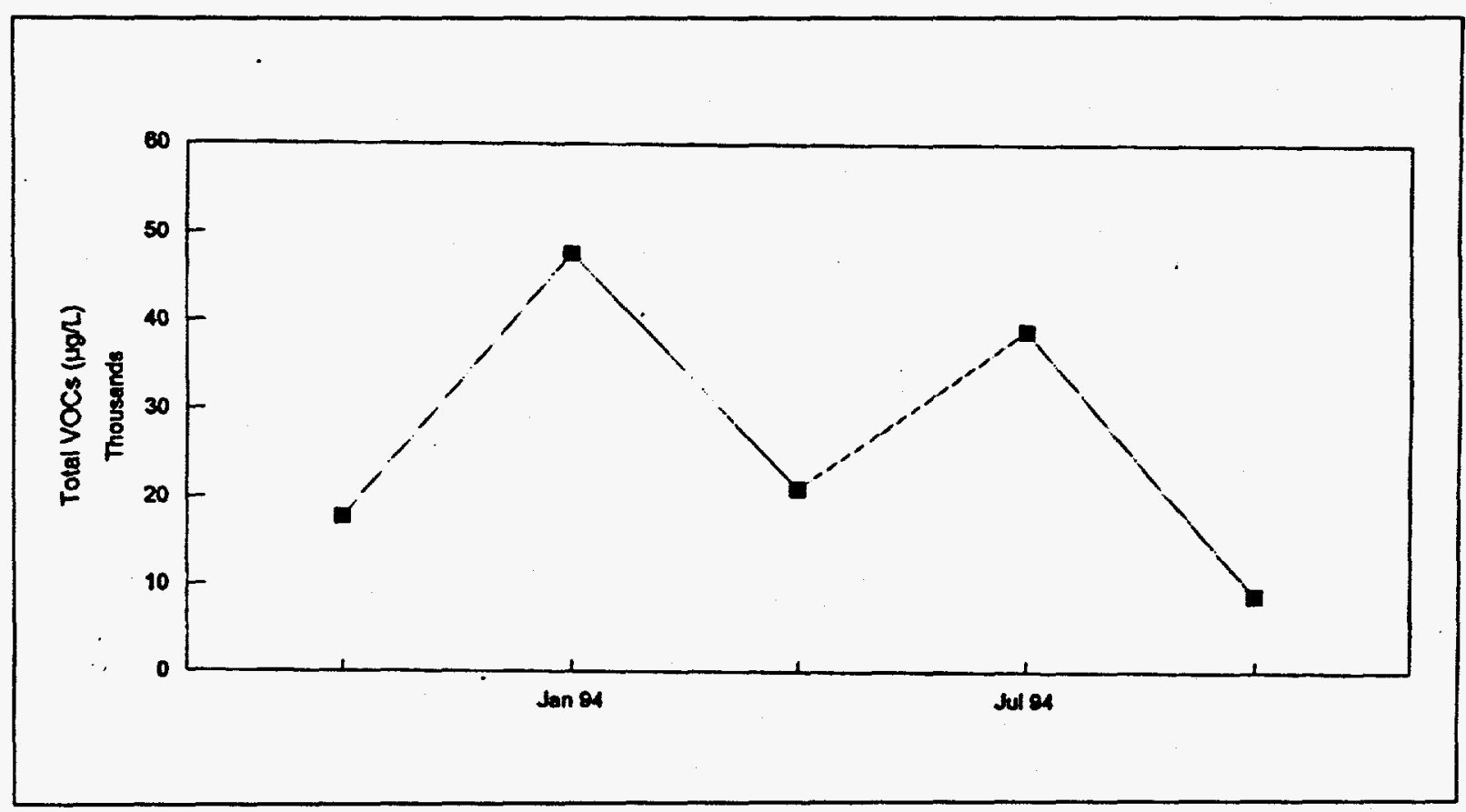

Figure 6-15. Concentration of Total VOCs Monitor Well NEMW-3D 


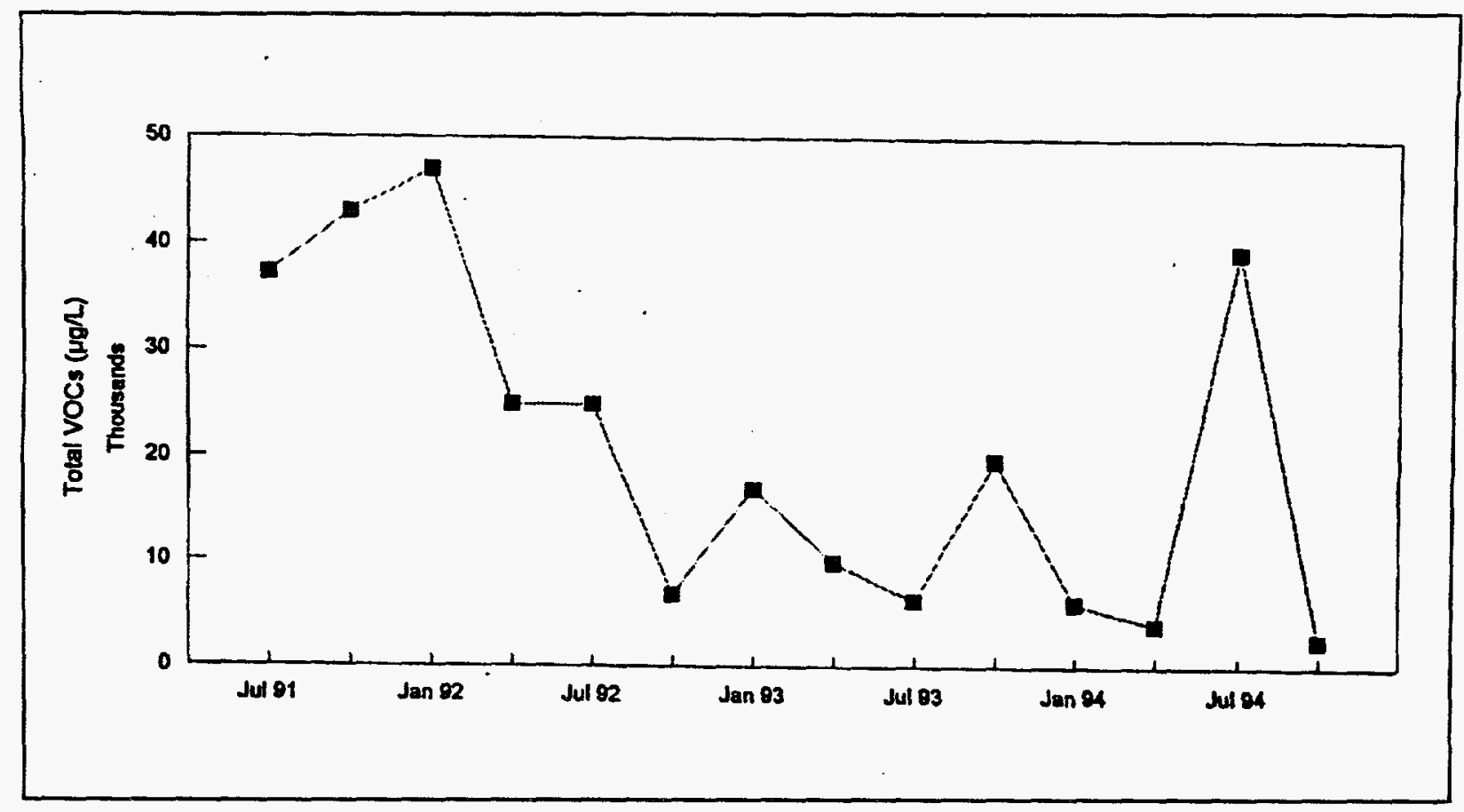

Figure 6-16. Concentration of Total VOCs Monitor Well NEMW-4

One potential new SWMU was identified during 1992. Notification of this potential SWMU, the West.Fenceline Area, was made by the Pinellas Plant to EPA in May 1992. Pursuant to this notification, an RFA Plan was developed and submitted in July 1992 and approved in September 1992. A comprehensive investigation which employed a subsurface hydrocone survey was conducted at this site. The results indicated limited contamination in the surficial aquifer. The plant submitted an RFA Report, which included RFI information, in November 1992 to the EPA for their review and approval. In August 1993, the Pinellas Plant HSWA Permit was modified to include the West Fenceline Area.

The Pinellas Plant submitted a CMSP in November 1993 to the EPA for the West Fenceline Area. Low levels of vinyl chloride in the groundwater near a former materials storage area has migrated to the facility boundary. Approval was granted for the CMSP in December 1993.

An air sparging and vapor extraction system is proposed for installation under interim measure status. The interim measures plan submittal for this system was submitted to the EPA and FDEP in March 1994 and subsequently approved in November 1994. The air sparging and vapor extraction system will be constructed in 1995.

Groundwater sampling conducted at the Pinellas Plant in 1992 indicated the presence of trichloroethene near the IWNF. Further investigation revealed specific areas of VOC contamination. Because this contamination was not determined to be associated with any other Pinellas Plant SWMU, the plant 
reported these results to the EPA and an RFA was performed. Analytical results from groundwater samples indicated that elevated levels of 1,2-dichloroethene, vinyl chloride, dichloromethane, and trichloroethene are present in the area and exceed regulatory levels [Ref. 5]. The EPA determined, based on the RFA, that an RFI is required. That investigation is in progress.

The implementation of interim corrective measures at the plant is consistent with EPA's goal for the RCRA Corrective Action Program. In EPA's draft Corrective Action Rule, the agency states: "One of the agency's overriding goals in managing the corrective action program will be to expedite cleanup results by requiring (taking) sensible early actions to control environmental problems on an interim basis." This goal is also consistent with the DOE's commitment to the environment; that is, addressing environmental issues in an efficient and thorough, yet cost-effective manner.

Figure 6-17 shows the cumulative volatile organics and groundwater removed from the restoration sites since May 1990. These data will provide valuable insight during planning of the final corrective measures. 


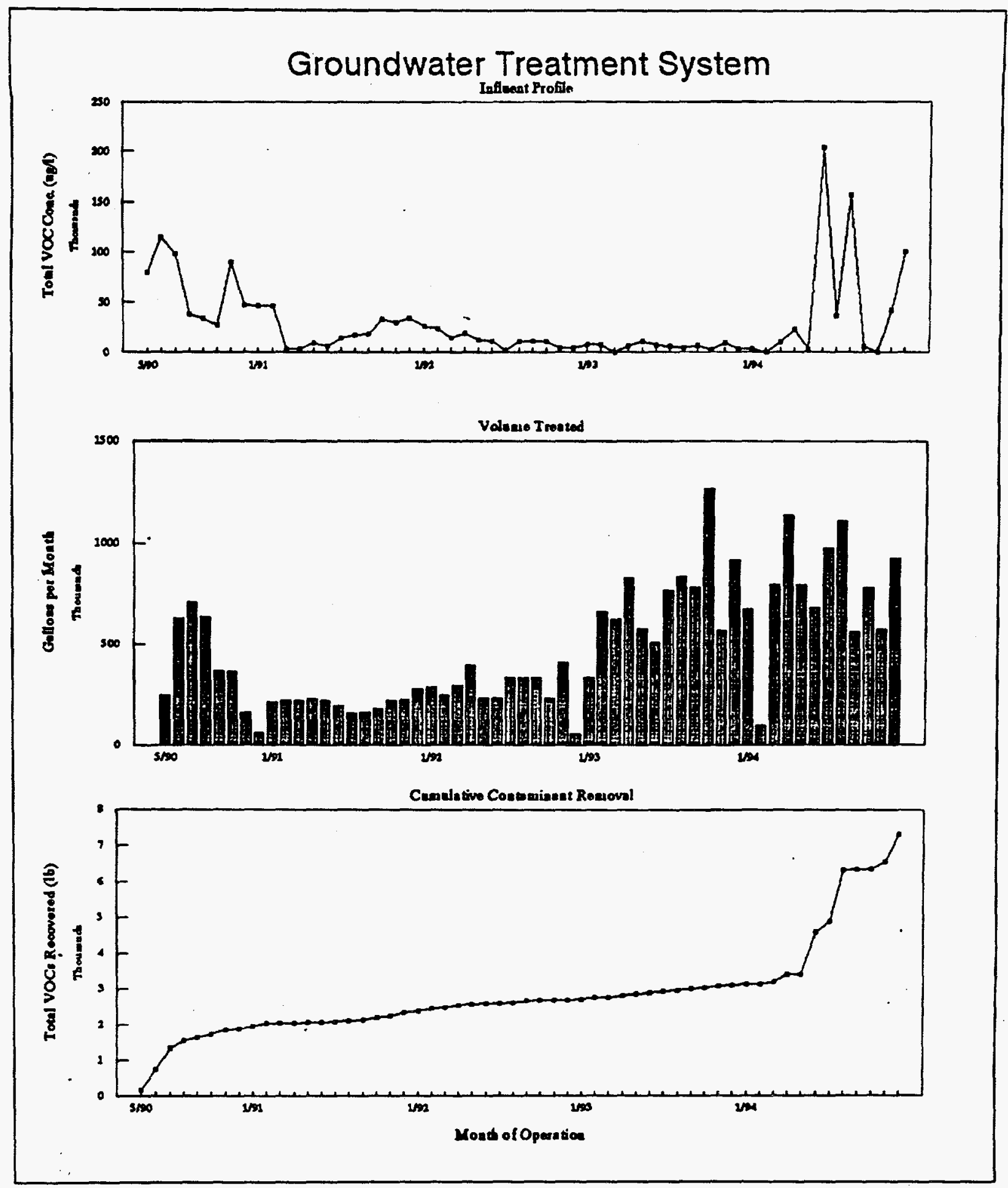

Figure 6-17. Recovery of VOCs in Pinellas Plant Groundwater Treatment System Since May 1990 


\subsection{QUALITY ASSURANCE}

DOE 5400.1, General Environmental Protection Program, requires that a QA program consistent with the requirements of DOE 5700.6, Quality Assurance, and

10 CFR 830.120, be established covering each element of the environmental monitoring and surveillance programs commensurate with its nature and complexity. Requirements for QA programs at the Pinellas Plant are defined in GOP J.1.06, Quality Assurance Program Plan, and in MMSC-QPP-0030, Pinellas Plant Quality Assurance Program.

DOE 5400.1 defines environmental monitoring as the collection and analysis of samples or direct measurements of environmental media. Environmental monitoring consists of two major activities: (1) effluent monitoring and (2) environmental surveillance.

The QA program for environmental monitoring at the plant is documented by MMSC-QPP-0028, Quality Program Plan for Environmental Monitoring. This program provides for the management, performance, assessment, and continuous improvement of environmental monitoring activities. This QA plan, specific to environmental monitoring activities, is consistent with and supplemented by the Quality Assurance Project Plan for Radionuclide Emissions, MMSC-EHS-0039; the Quality Program Plan for Environmental, Safety \& Health Programs, MMSC-QPP-0033; and the Quality Assurance Project Plan for the Meteorological Monitoring Station, MMSC-QAP-93120.

Sampling and analysis programs not covered by the Quality Program Plan for Environmental Monitoring are regulated by other QA program plans. Groundwater monitoring conducted at the 4.5-Acre Site is performed under the auspices of the FDEP through the approved Comprehensive Quality Assurance Plan, 890131G. Sampling and analysis activities performed on SWMUs of the miscellaneous sites are performed under the auspices of the EPA through an approved Site Specific Quality Assurance Project Plan and an RFI.

The Environmental Monitoring Program is defined and controlled through the issuance of Specialty Components Environmental Management Procedures. The Specialty Components Environmental Management Procedures are the governing documents for radiological and nonradiological environmental monitoring activities. These technical procedures for sampling and analysis programs are consistent with EPA methodologies and are reviewed and approved in accordance with EM-7.02, Preparation and Control of Environmental Monitoring Procedures. These documents are controlled using numbered procedure manuals. The documents are maintained by the Information Systems Department in accordance with sitewide document control procedures that include unique issue numbers, document identification, numbered pages, distribution records, revision tracking and a system for filing master copies.

Environmental protection specialists generate or modify Specialty Components Environmental Management procedures. New or modified procedures must undergo management review and approval prior to issuance and must be controlled through the sitewide document control system. Minor changes to documents such as inconsequential editorial corrections do not require the same review and approval as the original 
documents; however, it is the responsibility of the Specialty Components Environmental Management Procedure Coordinator to make this determination, as identified in EM-7.02.

The Specialty Components Environmental Management Procedure Coordinator reviews each Specialty Components Environmental Management Procedure annually to ensure accuracy. Any deviation from the provisions of the procedure must be approved by the Director-Environmental, Safety and Health or his/her delegated representative.

Each environmental monitoring sample is listed on a chain-of-custody record. Assurance for sampling integrity begins with the sample collector by the initiation of the chain-of-custody record as required by Specialty Components Environmental Management Procedure EM-6.01, Sample Custody Procedure, and continues with each person having physical custody of the sample. The document remains with the sample(s) at all times until the laboratory analysis is complete, and it is maintained as a permanent attachment to the analytical report. Once completed, the chain-of-custody record is an accountable document and is maintained and protected as a QA record. Training in sample custody protocol is provided to users by the Training and Education Programs organization as requested by Environmental, Safety and Health.

\subsection{Nonradioactive Eflluent}

Plant personnel collect and analyze effluent from the Pinellas Plant IWNF discharge to the PCSS to maintain compliance with the Pinellas County Industrial Wastewater Discharge Permit 153-IE, effective August 28, 1994. Plant utilities operators collect wastewater samples using sample collection instructions provided by Environmental, Safety and Health for inclusion into utilities operating procedures. Prior to sample collection, the utilities operators undergo "Water Sample Collection Training and Assessment," a performance-based training plan developed with the Training and Education Programs organization. This training ensures that the trainee has the appropriate water sample collection skills. Field blank(s) and field duplicate(s) are collected during sampling to evaluate the precision of the sampling technique and to detect any possible field contamination.

Plant personnel collect wastewater samples for metals, cyanide, BOD, TSS, and oil/grease for analysis per EM-3.02, Tritium and Chemical Constituents in Wastewater Discharged to the PCSS. All samples are submitted to the Pinellas Plant Chemical Technology-Analytical and Radioanalytical Laboratories for analysis. Chemical Technology is certified by the State of Florida for environmental water analyses performed in support of PCSS compliance. The sampling schedule and QA sampling frequency requirements are listed in Tables 7-1 and 7-2. 
Table 7-1. Wastewater Sampling Schedule

\begin{tabular}{|c|c|c|c|c|c|}
\hline Waste Stream & Tritium & Metals & BOD \& TSS* & Cyanide & Oil/Grease \\
\hline Sanitary & Daily & $* *$ & $* *$ & $* *$ & $* *$ \\
\hline Industrial & Daily & $\begin{array}{c}\text { 2nd workday } \\
\text { of week }\end{array}$ & $\begin{array}{c}\text { 1st Wed. of } \\
\text { month }\end{array}$ & $\begin{array}{c}\text { 2nd workday } \\
\text { of month }\end{array}$ & $\begin{array}{c}\text { 1st Wed. of } \\
\text { month }\end{array}$ \\
\hline Combined & Daily & $\begin{array}{c}\text { 2nd workday } \\
\text { of week }\end{array}$ & $\begin{array}{c}\text { 1st Wed. of } \\
\text { month }\end{array}$ & $\begin{array}{c}\text { 2nd workday } \\
\text { of month }\end{array}$ & $\begin{array}{c}\text { 1st Wed. of } \\
\text { month }\end{array}$ \\
\hline *Separate samples & \multicolumn{4}{|c|}{ *ot Required } \\
\hline
\end{tabular}

Table 7-2. QA Sample Frequency Requirements

\begin{tabular}{|l|l|l|}
\hline Parameter & Blank Frequency & Duplicate Frequency \\
\hline Tritium & 2/Week (Tues. \& Thurs.) & 2/Week (Tues. \& Thurs.) \\
\hline Metals & Weekly & 2/Month \\
\hline BOD \& TSS* & 1/Month & 1/Month \\
\hline Cyanide & 1/Month & 1/Month \\
\hline Oil/Grease & 1/Month & 1/Month \\
\hline *Separate samples & \\
\hline
\end{tabular}

The laboratory analyzes the samples in accordance with 40 CFR 136 , specified by the PCSS permit. The Pinellas Plant Chemical Technology Laboratories are responsible for the QA associated with this work. To assure quality of analytical performance, both precision and accuracy are monitored in all quantitative analytical measurements through the analysis of duplicate and spiked samples as designated in the Quality Assurance Plan for Wastewater Analyses, MMSC-EM-93068 and FDEP-approved Comprehensive Quality Assurance Plan, 940196.

\subsection{Radioactive Effluent and Monitoring}

Effluent from the plant IWNF is collected daily for tritium analysis as listed in Table 7-1. Process wastewaters contained in Health Physics holding tanks are sampled and analyzed for tritium prior to discharge to the IWNF and, ultimately, the PCSS. One field blank and field duplicate are collected monthly during the sampling event. Samples are collected by the utilities operators using sampling instructions provided by Environmental, Safety and Health.

Surface waters both on site (East, West, and South Ponds) and off site at 26 locations are monitored for tritium. Ponds are sampled weekly by the utilities operators. QA samples are collected with a frequency of one field blank and one duplicate for each sampling event. Off-site surface waters are collected quarterly 
by a field services subcontractor using procedure EM-4.02, Tritium in Off-Site Surface Waters. A minimum of one field blank and one field duplicate are collected each day; a minimum of three field blanks and three duplicates are collected for the set.

Environmental monitoring for tritium in air, conducted both on and off site, is discussed in Section 4.0 and is performed in accordance with EM-1.04, Tritium in Air On- and Off-Site Ambient Monitoring Stations. Preweighed silica gel columns provided by the Radioanalytical Laboratory are connected to the sample trains and are collected monthly by a field services subcontractor and returned to the laboratory.

Plutonium is monitored in air and soil, both on and off site. Air filters are collected bimonthly from four on-site locations and four off-site locations. Soil samples are collected annually from two of fourteen on-site locations and four of sixteen off-site locations on a rotating basis. The samples are collected by a field services subcontractor in accordance with EM-2.02, Plutonium in Air, On- and Off-Site Environmental Monitoring, and EM-5.01, Plutonium in Soil, On- and Off-Site Environmental Monitoring.

All radiological analyses are performed by the plant Chemical Technology-Radioanalytical Laboratory. Procedures are based on methods specified and approved by regulatory agencies. The laboratory is responsible for the quality assurance aspects of these analyses, as defined in MMSC-QPP-0025, Quality Program Plan for the Radioanalytical Laboratory.

\subsection{Data Management}

Each Environmental Monitoring Procedure delineates the responsibilities for review of the analytical data and data handling. The responsible Specialist-Environmental Protection retrieves, reviews, validates, and tracks and trends the data, and initiates corrective action, as appropriate. Anomalous data is addressed as prescribed by EM-7.05, Treatment of Anomalous Data. As specified in each applicable procedure, the monitored parameter is resampled to verify the data. An investigation is initiated to determine the root cause to prevent recurrence.

\subsection{Proficiency Testing Programs}

The plant participates in proficiency testing programs using spiked samples provided by governmental agencies to provide a quantitative measurement for evaluating internal and external laboratories in the analysis of environmental monitoring samples. The internal plant laboratories participate in third-party QA sample programs as defined in EM-7.03, Administration of Third-Party Quality Assurance Samples. A summary of the Third-Party Quality Assurance Program is listed in Table 7-3. The Environmental Oversight \& Quality Assurance 
function of the Quality, Ethics \& Compliance Programs Department administers the programs for Environmental, Safety and Health to ensure independent verification of laboratory activities.

Table 7-3. Third-Party Quality Assurance Program Summary

\begin{tabular}{|l|l|l|l|l|}
\hline $\begin{array}{l}\text { Samples } \\
\text { Provided By }\end{array}$ & Sample & Analysis & Frequency & $\begin{array}{l}\text { Plant } \\
\text { Laboratory }\end{array}$ \\
\hline DOE & EML*Soil & Plutonium & Semiannually & Radioanalytical \\
\hline DOE & EML Water & Plutonium & Semiannually & Radioanalytical \\
\hline DOE & EML Air Filters & Plutonium & Semiannually & Radioanalytical \\
\hline DOE & $\begin{array}{l}\text { EML H-3 in } \\
\text { water }\end{array}$ & Tritium & Semiannually & Radioanalytical \\
\hline EPA & $\begin{array}{l}\text { EMSL** H-3 in } \\
\text { water }\end{array}$ & Tritium & Semiannually & Radioanalytical \\
\hline EPA & $\begin{array}{l}\text { EMSL-LV Air } \\
\text { Filter }\end{array}$ & Gross Alpha & Annually & Radioanalytical \\
\hline $\begin{array}{l}\text { Analytical } \\
\text { Products } \\
\text { Group, Inc. }\end{array}$ & $\begin{array}{l}\text { P.E.T.** } \\
\text { Standards }\end{array}$ & $\begin{array}{l}\text { BOD, TSS, } \\
\text { Metals, Cyanide }\end{array}$ & Semiannually & Analytical \\
\hline $\begin{array}{l}\text { *nvironmental Measurements Laboratory } \\
\text { ** Environmental Monitoring Systems Laboratory - Las Vegas } \\
\text { ** Proficiency Environmental Testing (P.E.T.) Program }\end{array}$ & \\
\hline
\end{tabular}

The Radioanalytical Laboratory participates in radiological programs sponsored by the DOE Environmental Measurements Laboratory and EPA's Environmental Monitoring Systems Laboratory-Las Vegas. Participation includes the semiannual Environmental Measurements Laboratory (EML) Quality Assessment Program; the annual EMSL-LV Air Filter Performance Evaluation Study; and the semiannual Tritium in Water Performance Evaluation Study.

Nonradiological QA samples are submitted to the plant's Analytical Laboratory semiannually. These samples, supplied by Analytical Products Group, Inc., are part of the Proficiency Environmental Testing Program, an interlaboratory QA program designed to allow participating laboratories to evaluate their performance against that of other facilities. The program is based on analysis of unknown standards at two levels and is comparable to the EPA's performance evaluation programs.

A summary of the results of analysis of spiked samples provided by government Third-Party Quality Assurance Programs is listed in Tables 7-4 and 7-5. 
Table 7-4. 1994 Results of Analysis of Spiked Samples Provided by Government Third-Party Quality Assurance Programs

\begin{tabular}{|c|c|c|c|c|c|}
\hline Agency & Date & Sample & Analysis & Reported & Actual \\
\hline DOE & June & EML* Water & H-3 & $0.171 \times 10^{3}$ & $0.187 \times 10^{3} \mathrm{~Bq} \mathrm{~L}^{-1}$ \\
\hline DOE & Dec. & EML Air & Pu-238 & 0.070 & $0.072 \mathrm{~Bq} /$ filter \\
\hline$\overline{\mathrm{DOE}}$ & Dec. & EML Soil & $\mathrm{Pu}-239$ & 0.590 & $0.648 \mathrm{~Bq} /$ filter \\
\hline DOE & Dec. & EML Soil & $\mathrm{Pu}-238$ & 0.250 & $0.310 \mathrm{~Bq} \mathrm{~kg}^{-1}$ \\
\hline $\mathrm{DOE}$ & Dec. & EML Water & $\mathrm{Pu}-239$ & 8.300 & $7.780 \mathrm{~Bq} \mathrm{~kg}^{-1}$ \\
\hline $\mathrm{DOE}$ & Dec. & EML Water & $\mathrm{H}-3$ & 108.000 & $113.000 \mathrm{~Bq} \mathrm{~L}^{-1}$ \\
\hline EPA & Aug. & $\begin{array}{l}\text { EMSL-LV** } \\
\text { Air }\end{array}$ & Gross Alpha & $\begin{array}{l}32.0 \\
34.0 \\
35.0\end{array}$ & $35.0 \mathrm{pCi} / \mathrm{filter}$ \\
\hline EPA & March & $\begin{array}{l}\text { EMSL-LV } \\
\text { Water }\end{array}$ & $\mathrm{H}-3$ & $\begin{array}{l}5060.0 \\
4590.0 \\
4640.0\end{array}$ & $4936.0 \mathrm{pCi} / \mathrm{L}$ \\
\hline EPA & Aug. & $\begin{array}{l}\text { EMSL-LV } \\
\text { Water }\end{array}$ & H-3 & $\begin{array}{l}9029.0 \\
9550.0 \\
9630.0\end{array}$ & $9951.0 \mathrm{pCi} / \mathrm{L}$ \\
\hline
\end{tabular}

Unexpected personnel constraints and delays in the installation of the alpha spectrometer system precluded the laboratory from analyzing the June DOE EML QA samples for plutonium. Analysis of QA samples for uranium, performed in the past to maintain proficiency, is not a site requirement and was not conducted for either the June or December assessment events. 
Table 7-5. 1994 Results, Commercial Third-Party Quality Assurance Program (Analytical Products Group, Inc.)

\begin{tabular}{|c|c|c|c|c|c|}
\hline \multirow[b]{2}{*}{ Date } & \multirow{2}{*}{ P.E.T. Standard } & \multicolumn{2}{|c|}{ Reported } & \multicolumn{2}{|l|}{ Actual } \\
\hline & & Level 1 & Level 2 & Level 1 & Level 2 \\
\hline \multirow[t]{11}{*}{ May } & BOD, $\mathrm{mg} / \mathrm{L}$ & 172 & 4.8 & 166.200 & 4.960 \\
\hline & $\mathrm{TSS}, \mathrm{mg} / \mathrm{L}$ & 71.6 & 390 & 78.100 & 394.400 \\
\hline & Cadmium, $\mu \mathrm{g} / \mathrm{L}$ & 84.7 & 147 & 88.120 & 151.930 \\
\hline & Chromium, $\mu \mathrm{g} / \mathrm{L}$ & 51.0 & 266 & 45.920 & 278.280 \\
\hline & Copper, $\mu \mathrm{g} / \mathrm{L}$ & 31.7 & 273 & 32.460 & 278.230 \\
\hline & Lead, $\mu \mathrm{g} / \mathrm{L}$ & $43.5^{*}$ & 482 & 22.190 & 485.490 \\
\hline & Mercury, $\mu \mathrm{g} / \mathrm{L}$ & 1.29 & 3.23 & 1.190 & 3.090 \\
\hline & Nickel, $\mu \mathrm{g} / \mathrm{L}$ & 62.7 & 134 & 59.860 & 134.670 \\
\hline & Silver, $\mu \mathrm{g} / \mathrm{L}$ & 45.7 & 188 & 45.920 & 191.340 \\
\hline & Zinc, $\mu \mathrm{g} / \mathrm{L}$ & 74.7 & 96.7 & 77.720 & 103.630 \\
\hline & Cyanide, $\mathrm{mg} / \mathrm{L}$ & 0.917 & 1.45 & 0.916 & 1.266 \\
\hline \multirow[t]{11}{*}{ Nov. } & $\mathrm{BOD}, \mathrm{mg} / \mathrm{L}$ & 146 & 25.3 & 114.400 & 19.890 \\
\hline & TSS, $\mathrm{mg} / \mathrm{L}$ & 77.6 & 468 & 87.000 & 498.800 \\
\hline & Cadmium, $\mu \mathrm{g} / \mathrm{L}$ & 10.7 & 274 & 11.770 & 271.410 \\
\hline & Chromium, $\mu \mathrm{g} / \mathrm{L}$ & 427 & 546 & 441.220 & 556.620 \\
\hline & Copper, $\mu \mathrm{g} / \mathrm{L}$ & 304 & 626 & 294.060 & 600.490 \\
\hline & Lead, $\mu \mathrm{g} / \mathrm{L}$ & 293 & 679 & 288.570 & 666.620 \\
\hline & Mercury, $\mu \mathrm{g} / \mathrm{L}$ & 4.76 & 6.61 & 4.749 & 6.425 \\
\hline & Nickel, $\mu \mathrm{g} / \mathrm{L}$ & 454 & 722 & 442.690 & 709.000 \\
\hline & Silver, $\mu \mathrm{g} / \mathrm{L}$ & 8.83 & 228 & 10.150 & 221.060 \\
\hline & Zinc, $\mu g / L$ & 259 & 293 & 248.830 & 281.900 \\
\hline & Cyanide, $\mathrm{mg} / \mathrm{L}$ & 0.846 & 2.55 & 0.919 & 3.131 \\
\hline
\end{tabular}

The result for zinc, Level 1, was outside acceptable limits for the May event. The level for lead in this sample was determined to be within two times our Instrument Detection Limit (IDL). The laboratory decided to report this value instead of concentrating and rerunning the sample. In the future, if a result is within two times (and at the discretion of the Quality Assurance Officer, three times) the IDL, then a concentration step will be required.

In accordance with EM-7.03, Administration of Third-Party Quality Assurance Samples, laboratories exceeding the control limits for any particular parameter are notified of the difficulty and are required to begin an investigation to determine the cause and to implement corrective action, as applicable, to prevent recurrence. 
Laboratories failing two consecutive testing events for any parameter are not allowed to perform this analysis for the Specialty Components Environmental, Safety and Health Program until proficiency is achieved and verified by the Environmental Oversight \& Quality Assurance function.

\subsection{QA Program for Meteorology Station}

The Quality Assurance Project Plan (QAPP) for the Meteorological Monitoring Station, MMSC-QAP-93120, requires scheduled inspection, maintenance, and calibration of the meteorological instruments and data acquisition system. The plan specifies the requirements for trending on-site data and comparing the results with local National Weather Service data. The important objective of the Quality Assurance analysis is to ensure the accuracy of the climatological data used to support the radiological effluent monitoring and environmental surveillance program. All the requirements in the QAPP were implemented in 1994.

Data acquired by the Pinellas Plant meteorological station over the twelve-month period, from January to December 1994, was analyzed by a consultant based on criteria suggested in the "On-Site Meteorological Program Guidance for Regulatory Modeling Applications" (EPA, Revised 1993). The analysis results and conclusions were documented in a report. The consultant demonstrated that the meteorological measurements are in compliance with the requirements described in the DOE/EH-0173T Regulatory Guide, DOE 5700.6, 5400.5, and 5400.1. The consultant also compared on-site meteorological data with local airport data from St. Petersburg-Clearwater International Airport and Tampa International Airport. The consultant concluded that on average, the data from the two airports compared favorably with on-site data.

\subsection{Audit Program}

The Environmental Oversight \& Quality Assurance function of the Quality, Ethics, \& Compliance Programs Department provides independent oversight of Environmental, Safety and Health activities in accordance with GOP K.2.11, Environmental Oversight. Compliance audits/reviews and other assessments of line operations are conducted to ensure compliance with environmental laws, regulations, requirements, permits, DOE Orders, Specialty Components command media, and Lockheed Martin Corporate Environmental Management policies and procedures. Quality audits and surveillances of laboratories and other organizations performing work, both field and analytical, in support of the Specialty Components Environmental, Safety and Health Program are defined by EM-7.04, Administration of Environmental Monitoring Audit Program. Laboratories are audited annually to evaluate their technical capabilities and the adequacy of their QA programs. 
Auditing activities are accomplished using the practices set forth in Standard Operating Procedure (SOP) K.2.11-1, Environmental Oversight Audit Program Practices. An audit report is generated and any finding or notable deficiency requires a written response from the auditee along with a corrective action plan. Follow-up is conducted to verify that the corrective action is applicable and effective. These verification activities are documented, protected, and maintained as QA records. 
This page left blank intentionally. 


\subsection{REFERENCES}

1. Martin Marietta Specialty Components, Inc. Pinellas Plant Environmental Monitoring Plan. MMSC-EM-0012. Largo: 1994.

2. United States. Department of Energy. General Environmental Protection. DOE 5400.1. Washington: GPO, 1990.

3. United States. Department of Energy. Radiation Protection of the Public and the Environment. DOE 5400.5. Washington: GPO, 1990.

4. United States. Department of Energy. Environmental Protection. Safety and Health Protection Information Reporting Requirements. DOE 5484.1.

Washington: GPO, 1990.

5. United States. National Severe Storms Forecast Center, National Weather Service, U. S. Department of Commerce. Data Printout of Tornados in Florida, 1950-1980. Washington: GPO, 1981.

6. Algermissen, S.T. "Seismic Risk Studies in the United States," Proceedings of the Fourth World Conference on Earthquake Engineering. Vol. 1, Santiago, Chile: 1969.

7. United States. U. S. Department of the Interior. National Wetland Inventory. Fish and Wildlife Service. Washington: GPO.

8. United States. Department of Environmental Protection. National Emission Standards for Emissions of Radionuclides Other than Radon from Department of Energy Facilities. 40 CFR Part 61 Subpart H. Washington: GPO, 1995.

9. Martin Marietta Specialty Components, Inc. Pinellas Plant Annual Site Environmental Report for Calendar Year 1993. MMSC-ESH-93035. Largo: 1994.

10. Martin Marietta Specialty Components, Inc. Industrial Wastewater Discharge Permit. 153-IE. Largo: 1994.

11. United States. Department of Environmental Protection. National Categorical Pretreatment Standards, Metal Finishing Category. 40 CFR 433.

Washington: GPO, 1995.

12. Pinellas County, FL. Pinellas County Government. Ordinance 91-26. Clearwater: 1991.

13. United States. Department of Energy. Environment, Safety and Health Tiger Team Assessment of the Pinellas Plant. DOE/EH-0126. Washington: GPO, 1990.

14. Martin Marietta Specialty Components, Inc. Pinellas Plant Final Action Plan, Supplement 1, ES\&H Assessment of Pinellas Plant. NDPP-OSP-0070. Largo: 1991.

15. Martin Marietta Specialty Components, Inc. Air Operating Permit. AO52-233355. Largo: 1993. 
16. Martin Marietta Specialty Components, Inc. Final Action Plan Response to Defense Programs, February 1992 Technical Safety Appraisal (TSA). MMSC-OSP-0118. Largo: 1992.

17. Martin Marietta Specialty Components, Inc. Pinellas Plant Final Action Plan to Defense Programs, February 1992 Technical Safety Appraisal (TSA). MMSC-OSP-93052. Largo: 1992.

18. Pinellas County, FL. Pinellas County Government. Pinellas County Sewer Use. Ordinance No. 91-26. Clearwater: 1991.

19. Martin Marietta Specialty Components, Inc. Environmental Monitoring Procedures Manual For Environmental Management. Latest Revision. Largo. 


\subsection{DISTRIBUTION}

\section{Pinellas Plant}

Dr. Lawrence Hare, President

Lockheed Martin Specialty Components

P. O. Box 2908

Largo, FL 34649-2908

Ms. Virginia L. McCauley, Vice President

Lockheed Martin Specialty Components

P. O. Box 2908

Largo, FL 34649-2908

Mr. Edward Mayer, Director

Environmental Management

Lockheed Martin Specialty Components

P. O. Box 2908

Largo, FL 34649-2908

Mr. Charles Biedermann, Manager (14)

Environmental Restoration and Permitting

Lockheed Martin Specialty Components

P. O. Box 2908

Largo, FL 34649-2908

Ms. Delphine Delaneuville, Manager (5)

Waste Management/Minimization

Lockheed Martin Specialty Components

P. O. Box 2908

Largo, FL 34649-2908

\section{Federal Agencies}

Ms. Patrice Babar, Acting Director

EM-323 Waste Operations

U. S. Department of Energy

Trevion II

Washington, D.C. 20585-0002

Ms. Marilyn Bange, Chief

Waste Management Division

U. S. Department of Energy

Albuquerque Operations Office

Albuquerque, NM 87115
Mr. Carl Froede, Jr.

Remedial Project Manager

Environmental Protection Agency

Region IV

345 Courtland Street, N.E.

Atlanta, GA 30365

Mr. James M. Gaver (2)

U. S. Department of Energy

Savannah River Operations Office

Office of External Affairs

P. O. Box A

Aiken, SC 29801

Ms. Dawn Gillas, Team Leader

Environmental Programs

U. S. Department of Energy

Pinellas Area Office

P. O. Box 2900

Largo, FL 34649-2900

Ms. Sarah Hartson (40)

Environmental Compliance Specialist

U. S. Department of Energy

Pinellas Area Office

P. O. Box 2900

Largo, FL 34649-2900

Mr. David Ingle

Environmental Restoration Program Manager

U.S. Department of Energy

Pinellas Area Office

P. O. Box 2900

Largo, FL 34649-2900

Mr. William Gunter

Director, Criteria \& Standards Division

Office of Radiation Programs

U. S. Environmental Protection Agency

401 M Street, S. W.

Washington, D.C. 20460

M. Kleinrock, Director (2)

Environmental Compliance Division

U. S. Department of Energy, EM-22

Forrestal Building

1000 Independence Ave., SW

Washington, DC 20585 
Mr. Arthur Linton

Federal Facilities Coordinator

Environmental Protection Agency

Region IV

345 Courtland Street, NE

Atlanta; GA 30365

Mr. Ronald L. Petersen, Chief

Environmental Compliance Bureau

U. S. Department of Energy - SR/ECD

P.O. Box A

Aiken, SC 29802

Mr. Daniel R. Rhoades (2)

Director, Office of Site Operations

Defense Programs

U.S. Department of Energy, DP-24

19901 Germantown Road

Germantown, MD 20874

Mr. Gary Schmidtke

Waste Management Program Manager

U. S. Department of Energy

Pinellas Area Office

P. O. Box 2900

Largo, FL 34649-2900

Ms. G. Schreiner

Manager, Technical Information Program

U. S. Department of Energy

Albuquerque Operations Office

P. O. Box 5400

Albuquerque, NM 87115

Mr. Richard Sena, Director

Environmental Restoration Project Office

U. S. Department of Energy

Albuquerque Field Office

P. O. Box 5400

Albuquerque, NM 87115
C. L. Soden, Director (3)

Environmental Protection Division

U. S. Department of Energy Field Office

Albuquerque Operations Office

P. O. Box 5400

Albuquerque, NM 878115

K. I. Taimi, Director (5)

Office of Environmental Compliance

U. S. Department of Energy, EH-22

Forrestal Building

1000 Independence Ave., SW

Washington, DC 20585

Mr. John H. Hankinson, Jr.

Regional Administrator

Environmental Protection Agency

Region IV

345 Courtland Street, NE

Atlanta, GA 30365

U.S. Department of Energy

Office of Scientific and Technical

Information Center

P. O. Box 62

Oak Ridge, TN 37831

\section{State and Local Agencies}

Dr. Roberta Hammond

Department of Health \& Rehabilitative

Services

1317 Winewood Blvd.

Tallahassee, FL 32399-0700

(Epidemiological Study Contact)

Harlan W. Keaton

Public Health Physicist Manager

Department of Health and Rehabilitative

Services, Bldg. 18

Pine Hills Service Center

Orlando, FL 32868-0069 
Mr. David R. Bilodeau, Director

Pinellas County Emergency Management

Administration

400 South Fort Harrison Avenue

Clearwater, FL 34616

Ms. Ginger Wetherhall, Secretary

State of Florida

Department of Environmental Protection

Twin Towers Office Building

2600 Blair Stone Road

Tallahassee, FL 32399-2400

Dr. Lyle Jarrett, Director

State of Florida

Office of Radiation Control (PD HIR)

1317 Winewood Boulevard

Tallahassee, FL 32399-0700

Mr. Ray Dielman

Public Health Physicist

State of Florida

Health and Rehabilitative Services

Office of Radiation Control

300 31st Street North,

St. Petersburg, FL 33713

Dr. Richard D. Garrity (2)

State of Florida

Department of Environmental Protection

Southwest District Office

3804 Coconut Palm Drive

Tampa, FL 33619-8318

Ms. Martha Gray

Environmental Engineer

Department of Environmental Management

Pinellas County Technical Services Bldg.

440 Court Street

Clearwater, FL 34616
Mr. P. A. Hessling, Director

Pinellas County

Department of Environmental Management

Air Quality Division

16100 Fairchild Drive, Bldg. V-102

Clearwater, FL 33520

Mr. Robert Nave

Division of Emergency Management

1720 South Gadsden

Tallahassee, FL 32399

Mr. Todd Tanberg, Director

Pinellas County Sewer System

310 Court Street

Clearwater, FL 34616

\section{Others}

Mr. \& Mrs. David Akers

9959 82nd Street N

Largo, FL 34647

Dr. Elaine Anderson

10460 Longwood Dr

Largo, FL 34647

Mr. Chet Askey

456 26th Avenue N

St. Petersburg, FL 33704

Mr. Paul Bahmiller

10319 95th Street $\mathbf{N}$

Seminole, FL 34647

Ms. Sandy Barbeau

14989 Cromwell Dr.

Clearwater, FL 34624

Ms. Patricia T. Birnie

2001 83rd Avenue North, \#1252

St. Petersburg, FL 33742-2753

Mr. Joseph D. Borucki

8989 Lynwood Drive

Seminole, FL 34642 
Ms. Mary Brennan

State Representative

District 57

6251 44th Street North, Suite 7

Pinellas Park, Florida 34665

Ms. Lola Brett

Natural Resources

LWV North Pinellas Co.

1502 Okadia Drive

Clearwater, Florida 34624

Mrs. J. K. Brolon

10671 Andrew Lane

Largo, FL 34647

Mr. Joe Buonfiglio

724 115th Avenue North $\# 2202$

St. Petersburg, FL 33716

Mr. Bob Burk

2960 Tangerine Terrace

Palm Harbor, FL 34684

Mr. Brett Cahill

10008 B Pawnee Avenue

Tampa, FL 33617

Mr. Victor Corman

11961 97th Avenue

Seminole, FL 34642

Ms. Karen Jackson Costello

12235 66th Street N

Largo, FL 34643

Mr. Brian Costner

Energy Research Foundation

537 Harder Street

Columbia, SC 29205

Mr. Marshall Coviello

11911 66th Street, Lot 417

Largo, FL 34643
Ms. Gabriele S. Dailey

Dames \& Moore

3204B San Juan Street, West

Tampa, FL 33629

Ms. Judith M. Davis

2867 Whispering Drive S

Largo, FL 34641

Ms. Marion Davis, President

League of Women Voters

St. Petersburg Area

P. O. Box 11775

St. Petersburg, FL 33733

Ms. Kathleen DiVito

11189 Tradewinds Blvd

Largo, FL 34643

Mr. Robert G. Doan

4012 McKay Circle

Largo, FL 34640

Mr. Mark Douglas, Reporter

Channel 10 WTSP-TV

Box 10000

St. Petersburg, FL 33733

Ms. Helen Doyle

12377 69th Street N

Largo, FL 34643

Ms. Mamie Durham

League of Women Voters

8021 Sailboat Key Blvd., Apt. 202D

South Pasadena, FL 33707

Mr. \& Mrs. Paul Ebacher

11666 Tradewinds Blvd

Largo, FL 34643

Mr. Dan Eberts

1002185 th Street $N$

Largo, FL 34647

Ms. Deborah A. Fadool

Knollwoode Civic Association

8045 Cottonwoode Drive

Largo, FL 34643 
Mr. Robert Fay

Suncoast Sierra Club

5050 4th St. No., Lot 514

St. Petersburg, FL 33703

Ms. Mary Jane Fitzwater

9488 127th Ave., N

Largo, FL 34643

Ms. Robin Fonino

409 Bayview Street

Safety Harbor, FL 34695

Ms. Barbara Frances

12256 93rd Street N

Largo, FL 34643

Mr. William George

9230 136th Way N

Seminole, FL 34646

Ms. Crystal Gildea

9015 109th Terrace N

Largo, FL 34647

Mr. H. S. Gill

Dames \& Moore

4508 Brookwood Drive

Tampa, FL 33629

Mr. Alan Goldstein

Business Writer

St. Petersburg Times

P. O. Box 1121

St. Petersburg, FL 33731

Ms. Peggy Goodale 7232 118th Circle North

Largo, FL 34643

Mr. William Goulet

Manager, Consulting Services

Director, Hazardous Waste Operations

11300 43rd St., North

Clearwater, FL 34622
Ms. Mary Kay Green

10311 95th Street N

Largo, FL 34647

Mr. Terry Griffin

HSW Environmental Consultants

3820 Northdale Blvd.,Suite 210B

Tampa, FL 33624

Ms. Jane Hammer

120 Carlyle Drive

Palm Harbor, FL 34683

Ms. Pearlie M. Harris

3618 2nd Avenue South

St. Petersburg, FL 33711

Ms. Carol Henry

HSW Environmental Consultants

3820 Northdale Blvd., Suite 210B

Tampa, FL 33624

Ms. Frances Hoelper

9400 127th Ave., N

Largo, FL 34643

Ms. Jacalyn Howard

1629 Sandstone Court

Clearwater, FL 34616

Ms. Monica Hughes

12554 Starkey Road

Largo, FL 34643

Mr. James Jacobs

441 33rd Street $N$

St. Petersburg, FL 33713

Ms. Deborah Janecki

8496 Bardmoor Place

Largo, FL 34647

M. Robert F. Jilek

Pinebrook Estate Homeowners Association

11840 71st Circle North

Largo, FL 34643

Mr. Jerry Kaiser

832 Lakeside Terrace

Palm Harbor, FL 34687 
Mr. Fred Kenny

5641 80th Avenue N

Pinellas Park, FL 34665

Mr. David Kiewit

2420 Seneca Court

Palm Harbor, FL 34683

Ms. Catherine Klein

11321 North 50th Street \#19

Tampa, FL 33607

Dr. Richard D. Klein

Brown \& Root Environmental

900 Trail Ridge Road

Aiken, SC 29803

Ms. Mary Kovalsky

7126 118th Terrace North

Largo, FL 34643

Mr. \& Mrs. Mark Kuhns

1224 Markley Drive

Largo, FL 34640

Mr. \& Mrs. Fred Lair

8931 Merrimoor Blvd E

Seminole, FL 34647

Ms. Sue Landry

St. Petersburg Times

P. O. Box 1121

St. Petersburg, FL 33731

Mr. Tony Lester

Route 2, Box 86

Bowling Green, FL 33834

Mr. Ed Linde

1198072 Way North

Largo, FL 34643

Ms. Susan Maholm

9683 Leeward Avenue

Largo, FL 34643

Ms. Annette Mandis

38501 US Highway 19 North

Palm Harbor, FL 34684
Mr. Pat Marzulli

32212 th Avenue

Indian Rocks Beach, FL 34635

Ms. Moira McCaughey

South Pinellas Greens

6900 16th Avenue No.

St. Petersburg, FL 33710

Ms. Verlean Merritt

2689 Pinellas Point Drive South

St. Petersburg, FL 33712

Ms. Nancy Millichamp

6680 31st Terrace $N$

St. Petersburg, FL 33710

Ms. Nancy Milligan

8660 Maidstone Court

Largo, FL 34647

Mr. Paul Morrison

7825 Tiburon Drive

Largo, FL 34643

Mr. Kenneth Murray

12675 114th Street N

Largo, FL 34648

Ms. Patty Novak

7605 Cumberland Road

Largo, FL 34647

Mr. Ted Page

LLUVIA, Inc.

6822 22nd Avenue N, Room 149

St. Petersburg, FL 33710

Ms. Terry Perkins

Emmanuel Community

6680 31st Terrace North

St. Petersburg, FL 33710

Ms. Ginny Perrine

ERM - South, Inc.

9501 Princess Palm Avenue

STE 100

Tampa, FL 33619 
Mr. Matthew Pesce

Pinebrook Homeowners Association

12150 74th Street North

Largo, FL 34643

Mr. John H. Pillis, III

10893 97th Street N

Largo, FL 34643

Mr. Ron Priest

8046 Bayhaven Drive

Seminole, FL 34646

Ms. Maura Reedy

1201 Seminole Blvd., \#554

Largo, FL 34640

Mr. Richard Reynolds

NDL Partnership School/Child Development

Center

P. O. Box 2908

Largo, FL 34649

Mr. Daniel W. Rothenberger

14902 Winding Creek Court

Suite 101-C

Tampa, FL 33613

Ms. Eleanor Salkin

Senior Citizen Coalition of Hillsborough

400 East Harrison Street, \#507

Tampa, FL 33602

Mr. \& Mrs. William Sarti

2170 Nolan Drive S

Largo, FL 34640

Ms. Pam Scalese

5802 ,13th Avenue S

Gulfport, FL 33207

Ms. Carol Schaefnocker

ERM - South, Inc.

9501 Princess Palm Avenue, \#100

Tampa, FL 33619
Mr. Robert E. Schweiger

P. O. Box 98

Ozona, FL 34660

Ms. Joanne Shrewsbury

League of Woman Voters

9731 63nd Avenue N

St. Petersburg, FL 33708

Ms. Lisa Simmons

9488 127th Avenue N

Largo, FL 34643

Ms. Cynthia Smith

10266 95th Street N

Largo, FL 34647

Mr. Mike Smutko

System One

4902 Eisenhower Blvd.

Tampa, FL 33634

Mr. John D. Spence

10101 9th Street North

St. Petersburg, FL 33716

Mr. John Stewart

Emmanual Community

2130 Burlington Avenue N

St. Petersburg, FL 33710

Ms. Sheila Stewart

2130 Burlington Avenue N

St. Petersburg, FL 33713

Mr. Jeff Stidham, Reporter

Tampa/Pinellas Tribune

38501 U. S. $19 \mathrm{~N}$

Palm Harbor, FL 34684

Mr. John T. Stimus

PACE Laboratories, Inc.

5460 Beaumont Center Blvd.

Tampa, FL 33634

Mr. Bob Sullivan

Sierra Club, Suncoast Group

P. O. Box 16006

St. Petersburg, FL 33733-6006 
Mr. Michael Swann 9400 127th Avenue N largo, FL 34643

Ms. Deborah Sweeney 8185 83rd Avenue N

Seminole, FL 34647

Mr. Jerry Tetro

Trademark Homes 12173 Wild Acres Road Largo, FL 34643

Mr. Thomas I. Warren 10008 "B" Pawnee

Tampa, FL 33617
Mr. Davis Wogaman 12054 114th Street N

Largo, FL 34648-2543

Mr. Doyle Young

VA Medical Center 10000 Bay Pines Blvd

Bay Pines, FL 33504

Ms. Elena A. Zerfas

7133 Danbury Way

Clearwater, FL 34624 